

\section{DISCLAIMER}

This report was prepared as an account of work sponsored by an agency of the United States Government. Neither the United States Government nor any agency Thereof, nor any of their employees, makes any warranty, express or implied, or assumes any legal liability or responsibility for the accuracy, completeness, or usefulness of any information, apparatus, product, or process disclosed, or represents that its use would not infringe privately owned rights. Reference herein to any specific commercial product, process, or service by trade name, trademark, manufacturer, or otherwise does not necessarily constitute or imply its endorsement, recommendation, or favoring by the United States Government or any agency thereof. The views and opinions of authors expressed herein do not necessarily state or reflect those of the United States Government or any agency thereof. 


\section{DISCLAIMER}

Portions of this document may be illegible in electronic image products. Images are produced from the best available original document. 
Printed in the United States of America

Available from

National Technical Information Service

U.S. Department of Commerce

5285 Port Royal Road

Springfield, VA 22161

NTIS Price Codes: Printed Copy A07.

Microfiche A01

\section{DISCLAIMER}

This book was prepared as an account of work sponsored by an agency of the United States Government. Neither the United States Government nor any agency thereof, nor any of their employees, makes any warranty, express or implied, or assumes any legal liability or responsibility for the accuracy, completeness, or usefulness of any information, apparatus, product or process disclosed, or represents that its use would not infringe privately owned rights. References herein to any specific commercial product, process, or service by trade name, trademark, manufacturer, or otherwise, does not necessarily constitute or imply its endorsement, recommendation, or favoring by the United States Government or any agency thereof. The views and opinions of authors expressed herein do not necessarily state or reflect those of the United States Government or any agency thereof. 


\title{
GEOTHERMAL SOURCE POTENTIAL AND UTILIZATION FOR METHANE GENERATION AND ALCOHOL PRODUCTION
}

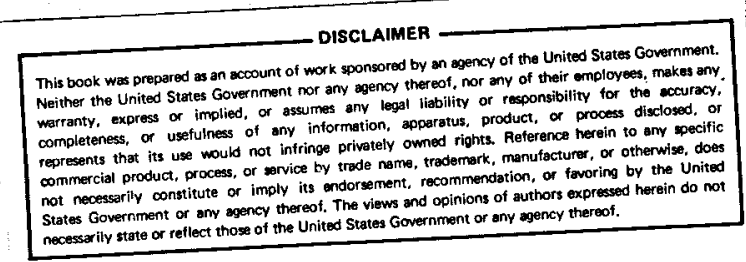

John C. Austin

Published November 1981

\author{
$\mathrm{CH}_{2} \mathrm{M}$ Hill \\ Boise, Idaho
}

Prepared for the EG\&G Idaho, Inc.

Under Subcontract No. K-1538, Modification 3

and the U.S. Department of Energy

Idaho Operations Office

Under DOE Contract No. DE-AC07-76ID01570 


\section{PREFACE}

This report was prepared for EG\&G Idaho by $\mathrm{CH}_{2} \mathrm{M}$ Hill on Subcontract No. K1538, Modification 3, under the Department of Energy's Outreach Program. It is now being reissued without modification as an EG\&G formal report in order to make it available to others that may be interested in this geothermal application. 


\begin{abstract}
A study was conducted to assess the technical and economic feasibility of integrating a geothermally heated anaerobic digester with a fuel alcohol plant and cattle feedlot. Thin stillage produced from the alcohol production process and manure collected from the cattle feedlot would be digested in anaerobic digesters to produce biogas, a mixture of methane and carbon dioxide, and residue. The energy requirements to maintain proper digester temperatures would be provided by geothermal water. The biogas produced in the digesters would be burned in a boiler to produce low-pressure steam which would be used in the alcohol production process. The alcohol plant would be sized so that the distiller's grains byproduct resulting from the alcohol production would be adequate to supply the daily cattle feed requirements. A portion of the digester

residue would substitute for alfalfa hay in the cattle feedlot ration.

The major design criterion for the integrated facility was the production of adequate distiller's grain to supply the daily requirements of 1,700 head of cattle. It was determined that, for a ration of 7 pounds of distiller's grain per head per day, a 1 million gpy alcohol facility would be required.

An order-of-magnitude cost estimate was prepared for the proposed project, operating costs were calculated for a facility based on a corn feedstock, the economic feasibility of the proposed project was examined by calculating its simple payback, and an analysis was performed to examine the sensitivity of the project's economic viability to variations in feedstock costs and alcohol and distiller's grain prices.
\end{abstract}




\title{
TECHNICAL AND ECONOMIC FEASIBILITY
}

GEOTHERMAL SOURCE POTENTIAL AND UTILIZATION FOR METHANE GENERATION AND ALCOHOL PRODUCTION

\author{
PREPARED FOR \\ BOYD ANDERSON
}

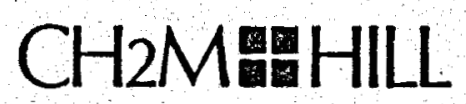

SEPTEMBER 1980 
TECENICAL AND ECONOMIC FEASIBILITY

GEOTHERMAL SOURCE POTENTIAL AND UTILIZATION

FOR

METHANE GENERATION AND ALCOHOL PRODUCTION

Prepared for

BOYD ANDERSON

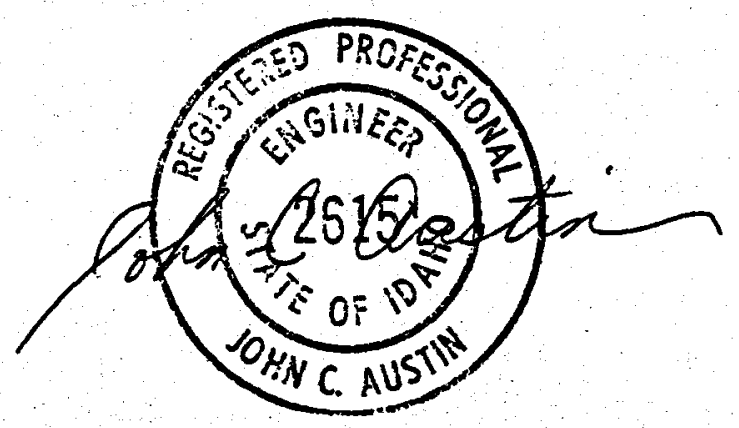

Prepared by

CH2M HILL CENTRAL, INC.

September 1980

Project No. B12738.A1 
A study was conducted for Boyd Anderson to assess the technical and economic feasibility of integrating a geothermally heated anaerobic digester with a fuel alcohol plant and cattle feedlot. Thin stillage produced from the alcohol production process and manure collected from the cattle feedlot would be digested in anaerobic digesters to produce biogas, a mixture of methane and carbon dioxide, and residue. The energy requirements to maintain proper digester temperatures would be provided by geothermal water. The biogas produced in the digesters would be burned in a boiler to produce low pressure steam which would be used in the alcohol production process. The alcohol plant would be sized so that the distiller's grains byproduct resulting from the alcohol production would be adequate to supply the daily cattle feed requirements. A portion of the digester residue would substitute for alfalfa hay in the cattle feedlot ration.

The major design criterion for the integrated facility is the production of distiller's grain adequate to supply the daily requirements of 1,700 head of cattle. It was determined that a 1-million-gallon-per-year alcohol facility would be required based on a ration of 7 pounds of distiller's grain per head per day. In addition to the anhyorous alcohol and distiller's grain, the alcohol production process would also produce large quantities of thin stillage which could be anaerobically digested to produce biogas. It was determined that sufficient quantities of biogas can be produced through the anaerobic digestion of the thin stillage and manure collected from the cattle feedlot to provide approximately 14,000 of the 30,000 Btu required to produce each 
gallon of alcohol. It is assumed that the remaining energy requirements for the alcohol production process would be supplied with fuel oil.

The study assumes that alcohol production based on atmospheric processes which use low pressure steam is most practical for the proposed project. Numerous atmospheric alcohol production processes exist and no attempt was made to select a single process for this study. All processes are similar in design and operation. The optimum system should be one of the subjects of the project preliminary design. Based on information gathered from several vendors, an order-ofmagnitude cost estimate was prepared for the proposed project. The project, including the alcohol production facility, anaerobic digesters, and geothermal well, is estimated to cost $\$ 3,980,000$.

The operating costs were calculated for a facility based on a corn feedstock. While it is anticipated that the proposed facility will have the capability to use a variety of feedstocks, it was assumed that the average feedstock cost will approximate $\$ 1.23$ per gallon, which is equivalent to the corn feedstock in this study. The total operating and maintenance cost associated with the proposed project was estimated at $\$ 1,920,000$ per year.

The study assumes that the sale of alcohol at $\$ 1.80$ per gallon will yield $\$ 1,800,000$ per year. The addition of the distiller's grains and digester residue, valued at $\$ 3.08$ per bushel and $\$ 70$ per ton, respectively, increases the estimated annual revenue to $\$ 2,097,000$.

The economic feasibility of the proposed project is examined by calculating its simple payback. Based on the above data, the proposed project has a simple payback of 22.5 years. An 
analysis was performed to examine the sensitivity of the project!s economic viability to variations in feedstock costs and alcohol and distiller's grain prices. The analysis indicates that a small change in the cost of the feedstock or the selling price of the alcohol produces a large change in the project's profitability. Changes in the selling prices of the distiller's grain is not nearly as significant as changes in the other two items.

It should be noted that there is no absolute value which indicates an acceptable payback for a project. The calculations shown in the financial and sensitivity analyses are merely relative indicators which may be used in comparing several alternative investments. An acceptable simple payback must be determined in the context of other alternative investment options and the projected risk associated with the proposed project. In addition, a detailed financial analysis must obviously consider financing costs, investment tax credits, and depreciation. 
SUMMARY AND CONCLUSIONS i

BACKGROUND 1

GEOTHERMAL RESOURCE ASSESSMENT $\quad 3$

Geologic Setting 3

Geothermal Potential 3

ALCOHOL PRODUCTION PROCESS DESCRIPTION $\quad 6$

Grain Preparation 6

Saccharification $\quad 6$

Fermentation 9

Distillation $\quad 10$

Dehydration 11

Stillage 13

$\begin{array}{ll}\text { ALCOEOL PRODUCTION MASS BALANCE } & 15\end{array}$

ALCOHOL PRODUCTION ENERGY BALANCE 17

Process Energy Requirements. 17

Thermal Energy System : 21

ALCOEOL PRODUCTION TAX INCENTIVES 22

BIOGAS GENERAL DESIGN CRITERIA 24

BIOGAS PROCESS DESCRIPTION

BIOGAS FACILITY DESCRIPTION 27

Raw Manure Preparation and Mixing 27

Anaerobic Digesters, Gasholder Tank, . . 27

Centrifuges, Sludge Bunker, and
Centrate Lagoon

BIOGAS MATERIAL BALANCE $\quad 29$

BIOGAS CENTRIFUGE RESIDUE UTILIZATION 33

CAPITAL COST 34

LEGAL IMPLICATIONS OF USING DIGESTER RESIDUE
FOR CATTLE FEED

INTEGRATED OPERATION $\quad 39$ 
CONTENTS

Continued

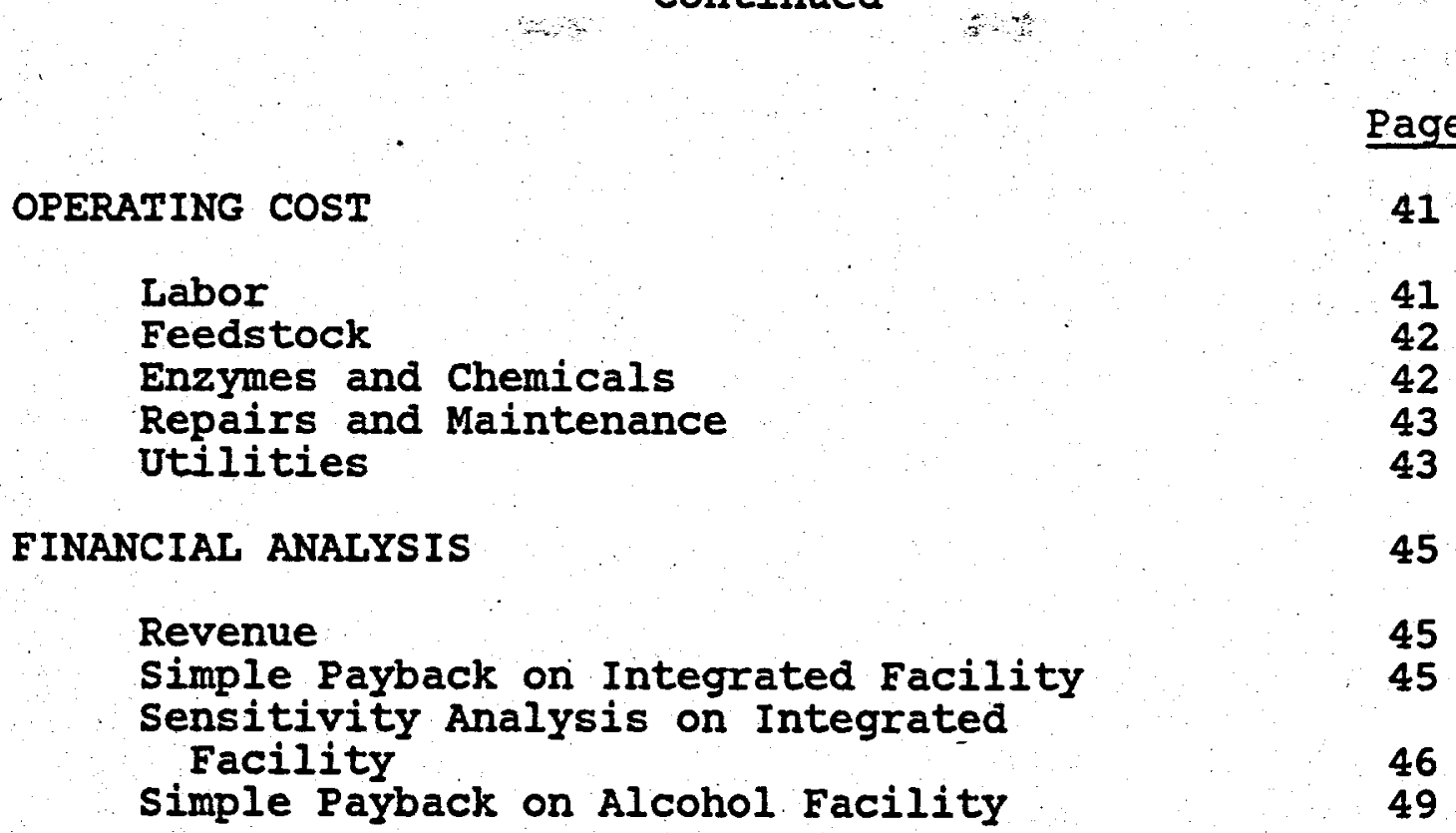

\section{TABLES}

1 Alcohol Process Thermal Requirements 19

2 Anaerobic Digester Residue 33

3 Capital Costs $\quad 35$

4 Alcohol Plant operating cost 41

5 Simple Payback 47

6 Project Sensitivity Analysis 48

FIGURES

1 Overall Schematic Diagram of Alcohol Process 7

2 Process Mass Balance 16

3 Process Energy Balance 18

4 Anaerobic Digester Mass Balance 31

5 Integrated Operation $\quad 40$

\section{APPENDICES}

A Alcohol Fuels Tax Incentives

B Feeding Regulations for Colorado and oregon 
BACKGROUND

Colonel Robert DeShazo and Mr. Boyd Anderson own large ranches near Mora, Idaho. Currently, these ranches produce several crops and support a large herd of dairy cows and beef cattle. As the interest in fuel-grade alcohol increased around the country, these ranchers concluded that an alcohol plant which produced anhydrous alcohol for fuel and distiller's grain for cattle feed might prove to be an economically attractive venture. Since data on existing wells in the area surrounding these ranches indicated the presence of a geothermal resource, Mr. Deshazo and Mr. Anderson speculated that geothermally heated methane digesters might significantly improve the energy balance for the proposed integrated facility.

To examine the potential of the geothermal source and the technical and economic feasibility of the proposed project, Mr. DeShazo applied to EGGG for a technical assistance grant. Upon receiving the grant, CH2M BILL was commissioned to conduct a study to determine the technical and economic feasibility of the proposed project. The study was to examine how the alcohol plant, cattle feedlot, and anaerobic digesters could most effectively be integrated. Based on the data collected during the study and data provided by Colonel DeShazo and Mr. Anderson, the economic viability of the proposed project was to be examined. The data and conclusions collected during the study are contained in this report.

This report is broken down into three parts. Part one examines the optimum size plant to integrate with the existing feedlot operation. The feedstock and energy require- 
ments of the facility are estimated, as are the product and byproducts. Part two of the report examines the important design and operating parameters for the biogas facility. Part three of the report studies how all of these facilities can be integrated into a successful commercial operation. The capital cost and operating and maintenance costs are estimated, as are the returns from the various products and byproducts. A simple payback is then calculated to provide an indication of the economic viability of the proposed project. 
GEOTHERMAL RESOURCE ASSESSMENT

\section{GEOLOGIC SETTING}

The Mora, Idaho, area is located in the western snake River Plain, an arcuate, northwest-trending graben in South-Central and Southwestern Idaho. The rocks in the area include several thousand feet of lacustrine and fluvial sediments that are underlain by a thick section of Tertiary basalts and interbedded sedimentary rocks (Wood and others, 1980).

\section{GEOTHERMAL POTENTIAL}

The western Snake River Plain has considerable geothermal potential. Numerous thermal springs and wells are known in this part of Idaho (Mitchell and others, 1980). The region is characterized by high heat flow and elevated geothermal gradients (Smith, 1980), Wells in the Nampa area commonly encounter water temperatures of approximately $104^{\circ} \mathrm{F}\left(40^{\circ} \mathrm{C}\right)$ at depths of about 2,000 feet $(610 \mathrm{~m})$. In deep petroleum test wells water temperatures in excess of $212^{\circ} \mathrm{F}\left(100^{\circ} \mathrm{C}\right)$ have been measured at depths greater than 7,000 feet $(2,133 \mathrm{~m})$.

Recent investigations (Wood and others, 1980) suggest that 1,000 to 2,000 feet $(305-610 \mathrm{~m})$ deep sandstone aquifers in the Nampa area may contain warm waters ranging from $86^{\circ}$ to $131^{\circ} \mathrm{F}\left(30^{\circ}\right.$ to $\left.55^{\circ} \mathrm{C}\right)$. The exact depth of these sandstone units can generally be determined from seismic reflection data. The production characteristics of these warm water aquifers is unknown. It is hoped that they will have sufficient permeability and thickness to yield sufficient fluid volumes. 
In the Boise area, there is similar potential. As of september 19, 1980, the Boise driling project had progressed to a depth of about 1,600 feet and had encountered temperatures of approximately $130^{\circ} \mathrm{F}$. No producing aquifers had yet been reached.

The geothermal potential of the Mora area is probably similar to that of the Nampa-Boise area, assuming that the aquifers discussed by wood and others (1980) are present. seismic reflection data would be useful to resolve this question. Information on the temperature potential at depths greater than about 2,000 feet can be obtained by an analysis of the well logs from the J. N. James No. I well (T4N, RIW, Sec. 27), a 14,000-foot oil test well drilled about 15 miles northwest of Mora, Idaho, by the Michel T. Halbouty Company. The bottom hole temperature in this well (recorded 11.5 hours after circulation) was $350^{\circ} \mathrm{F}$, yielding a gradient of about $2.5^{\circ} \mathrm{F} / 100 \mathrm{ft} .\left(40^{\circ} \mathrm{C} / \mathrm{km}\right)$. Whether sufficient quantities of water are available at these greater depths and temperatures is presently unknown.

\section{References cited}

Mitchell, J. C., Johnson, I. L., and Anderson, J."E., 1980 , Geothermal Resources of Idaho in Geothermal Investigations in Idaho, Part 9, Potential for Direct Heat Application of Geothermal Resources: Idaho Department of Water Resources Bulletin No. 30 , plate 1 .

Smith, R. N., 1980, Heat Flow in the western snake River Plain, (M.S. Thesis): Pullman, Washington state University, $150 \mathrm{p}$. 
Wood, S. H., Mitchell, J. C., and Anderson, J., 1980, Subsurface Geology and Geothermal Prospects in the Nampa-Caldwell area of the Western Snake River Plain, Idaho: Geothermal Resources Council Trans. Vol 4, p. 265-267. 
The production of alcohol via fermentation is a well established process consisting of five basic steps: grain preparation, saccharification, fermentation, distillation, and dehydration (see Figure 1). The following description gives a general outline of each process step. It should be noted that there are innumerable variations within each of these steps and that the following descriptions are merely representative of common operating conditions.

\section{GRAIN PREPARATION}

Grain preparation consists of transporting the grain over a series of vibrating screens and magnets to remove any foreign material. The grain is then transported to a roller or hammer mill where it is crushed to a fine mesh. The final size of this finely ground material, called meal, varies considerably from process to process. In general, the finer the material, the more efficient the saccharification process. However, finer material increases the difficulty of separating and drying the distiller's grain contained in the spent beer. Grain is typically not ground finer than 20 mesh.

\section{SACCHARIFICATION}

Saccharification is the process in which the starch contained in the grain feedstock is converted into simple sugars which can be fermented into alcohol. The saccharification process consists of several steps including slurrying, precooking, cooking, and final conversion. 

The meal is metered into a slurry tank where water is added with agitation to produce the grain slurry. Some processes slurry the grain with cold water and then pump the slurry to the precook tank where the temperature is raised to approximately $170^{\circ} \mathrm{F}$, alpha amylase is added, and the $\mathrm{pH}$ is adjusted to 6.0 to begin the conversion process. Other processes combine the slurry and precooking step by slurrying with hot water and adding the alpha amylase in the slurry tank.

Alpha amylase is an enzyme which converts starch into complex sugars called dextrins. The precooking step begins the conversion of the readily available starch. The time required for this conversion is dependent upon the temperature and the particular strain of enzyme being used. When sufficient time has lapsed so that the free starch has been converted into dextrin, the slurry is pumped to the cooker where the temperature is raised. Atmospheric cookers raise the slurry temperature to approximately $200^{\circ} \mathrm{F}$, while pressurized cookers may raise the temperature as high as $320^{\circ} \mathrm{F}$. This increase in temperature releases the starch contained within the grain cells and allows the enzyme to convert this newly released starch into dextrin. This two-step process (precooking, cooking) prevents excessive viscosity buildup in the slurry.

When sufficient time has lapsed so that the majority (>95 percent) of the starch originally contained in the grain is converted into dextrin, the mash is pumped to the saccharification tank where it is cooled through either heat exchangers or cold water dilution to approximately $151^{\circ} \mathrm{F}$, and the $\mathrm{pH}$ is adjusted to 4.5. Another enzyme, gluco-amylase, is then added to the mash, which converts the complex sugars, dextrins, into simple fermentable sugars. Upon completion of this conversion step, the saccharification process is 
complete. While conversion times are temperature dependent, atmospheric conversion systems typically required apprapimately 24 hours to convert 95 to 98 percent of the starch available in the grain to fermentable sugars. Pressurized cooking schemes require less time.

\section{FERMENTATION}

The sugar solution produced in the saccharification process is converted to alcohol in the fermenters. Fermentation is promoted by yeast cells which feed on the sugar and produce alcohol and $\mathrm{CO}_{2}$, as expressed in the following equation:

$$
\mathrm{C}_{6} \mathrm{E}_{12} \mathrm{O}_{6}+\text { yeast } \rightarrow 2 \mathrm{CO}_{2}+2 \mathrm{C}_{2} \mathrm{H}_{5} \mathrm{OH}
$$

Thus, if complete conversion is attained, about 51 percent of the sugar has been converted to alcohol and 49 percent to $\mathrm{CO}_{2}$.

Other minor byproducts formed include succinic acid, fatty matter, glycerine, and cellular matter. The cellular matter is contributed by the continual propagation of yeast in the fermenters. The actual quantity of byproducts formed will vary at each facility and is dependent on the yeast strain used and other substances present in the feed mash.

Inasmuch as the yeast is self-propagating in the fermenters, new yeast is added only on a limited basis to maintain yeast viability.

In the past, the fermenters have normally been operated in a batch mode. In this mode, the mash is cooled to $90^{\circ} \mathrm{F}$ and the necessary yeast is added to the fermenting vessel. Fermentation requires 20 to 48 hours, depending on the 
actual operating conditions. Upon completion of this cycle, the alcoholic solution, commonly called beer and containing up to 12 percent alcohol in water, is removed and sent to the distillation section. The fermenting vessels are then sterilized with steam before being recharged for another fermentation cycle.

The normal batch fermentation consumes both time and energy inefficiently. The continuous process is a more effective approach to fermentation. In the continuous process, the sugar solution flows into a fermenting vessel, or into several vessels operated in series, with a total residence time sufficient to complete fermentation.

Fermenters are simply steel vessels with sloping bottoms, closed tops, and vents to permit $\mathrm{CO}_{2}$ removal.' In addition, cooling coils are provided to maintain the $90^{\circ} \mathrm{F}$ fermenting temperature, since the conversion of sugar to alcohol is an exothermic reaction. The necessary amount of cooling water for the fermenters is highly dependent on the strain of yeast used and other operating parameters.

The beer from the fermenter contains solids in the alcoholwater stream. For the case of corn, these solids consist of spent yeast, unconverted starch, and fiber from the raw material.

\section{DISTILLATION}

The beer stream leaving the fermenter contains 8 to 12 percent alcohol. Almost all of the water and essentially all of the impurities contained in this beer are removed in the distillation section. The beer leaving the fermenter at its 
fermentation temperature, $90^{\circ} \mathrm{F}$, is preheated by the spent beer leaving the column bottoms to approximately $170^{\circ} \mathrm{F}$. This hot beer is then pumped into the distillation stripping column where virtually all of the alcohol and some of the water is stripped from the beer. The alcohol-water solution exits from the top of the column and spent beer exits from the bottom of the column. The composition of the alcoholwater leaving the stripping column can vary widely, depending upon the design of the system. This stream typically ranges from 80 to 160 proof.

The alcohol-water stream leaving the stripping column enters the rectification column where distillation continues to separate the alcohol from the water. An azeotrope between water and alcohol prevents the alcohol from being concentrated past 192 proof in a simple distillation system, and in practice, 190 proof is normally achieved. The 190 proof alcohol leaves from the top of the rectification columm while the water leaves from the bottom.

The above description of the distillation process is very simplistic and, in fact, a distillation process in an alcohol production facility is much more complex. While some systems do use relatively simple flow and energy schemes, other systems use highly integrated recycle streams, vacuum systems, and vapor recompression systems to improve column performance and reduce energy consumption.

\section{DEHYDRATION}

The final step in the production of absolute alcohol is the dehydration process which removes the remaining 5 percent water in the alcohol-water mixture. Breaking the alcohol- 
water azeotrope can be accomplished by either ternary azeotropic distillation, entrainment distillation, molecular seives, or vacuum distillation.

The most common method currently in use to produce anhydrous alcohol is ternary azeotropic distillation. In this process, another component, such as benzene, is added to the alcoholwater azeotrope to form a ternary azeotrope. Distillation of this minimum-boiling ternary azeotrope allows the anhydrous alcohol to separate from the water-benzene mixture and exit the bottom of the column. The water-benzene stream is then treated to recover the benzene. This system allows continuous recycle of the benzene and losses of this material usually do not exceed 0.05 percent, based on the volume of the absolute alcohol produced. Again, the above discussion is somewhat simplistic. Actual operation of a dehydration unit is more complex than described here.

Recently, a system which uses extractive distillation was patented which could potentially simplify the dehydration process and reduce its energy requirements. In extractive distillation, a material is introduced at the top of the rectifying column, which breaks the alcohol-water azeotrope by absorbing the water and allows anhydrous alcohol to exit from the top of the rectifying column. This material works its way down the column and exits with the column bottoms. Usually the material is recovered and processed for reuse. While this extractive distillation system has been patented, it has not yet been commercially demonstrated.

Molecular sieves can also be used to entrain the water in the alcohol-water azeotrope and, thereby, produce anhydrous alcohol. In this case, the azeotrope is passed through a column that is packed with molecular sieves. The sieves act 
as a water sponge and soak up the water while leaving the alcohol unaffected. As the alcohol-water mixture passes down the column, the alcohol becomes enriched as the water is absorbed. The stream leaving the column is virtually anhydrous. When the column efficiency drops to a predetermined level, the column can be drained and recharged by passing hot gases or steam up through the molecular sieves. While this system offers simplicity of design, the initial capital cost is comparatively high and the operating energy. requirements are not as good as some other systems.

The water-alcohol azeotrope can be broken under vacuum conditions. Eowever, as the pressure in the distillation column is reduced, the column diameter and number of plates increase. Numerous studies have indicated that while the production of anhydrous alcohol is possible using various vacuum systems, the dramatic increase in the column size prevents this technique from being a practical alternative.

\section{STILIAGE}

The most significant waste stream from the alcohol production process is the stillage which is removed from the bottom of the stripping column. The stillage consists of water, dissolved and suspended solids, and a small amount of alcohol. The solids contained in the stillage consist of approximately one-third of the initial feedstock material and are a valuable animal feed which must be recovered in order to obtain an acceptable economic return on the alcohol plant.

The stillage is usually passed through a belt press or centrifuge to remove the suspended solids which are approximately 60 percent of the total solids contained in the 
stillage. These separated solids, called light distiller's grain, can be pressed to approximately 30 percent solids and then dried in a rotary dryer to 90 percent solids.

The dissolved solids contained in the stillage can be collected by evaporating the majority of the stillage to form a syrup and then adding the syrup to the distiller's grain in the rotary oryer to produce dark distiller's grain. This process, while technically sound, is not economically attractive for smaller production facilities due to the high energy requirements and capital equipment costs associated with the process.

The thin stillage containing the dissolved solids can be treated in an anaerobic digester or filter to reduce the BOD and COP of the stream while producing methane which can provide some of the energy requirements of the alcohol process. This waste treatment process is not currently in widespread use, but is gaining acceptance as energy costs continue to climb.

Finally, the thin stillage can be treated as a waste stream and sewered. 
ALCOHOL PRODUCTION

MASS BALANCE

The proposed alcohol production facility will be designed to convert corn into alcohol, carbon dioxide, and dried distiller's grain. The mass balance assumes that a bushel of corn ( 56 pounds, 14 percent moisture) produces 2.5 gallons of alcohol.

Figure 2, the process schematic for corn derived alcohol, shows 64,500 pounds of corn per day converted into 19,000 pounds (2,880 gallons) of alcohol, 18,200 pounds of carbon dioxide, and 215,300 pounds of stillage at approximately 8.5 percent solids. The stillage is screened and the distiller's grain which is collected is pressed to 30 percent solids. This moist cake containing 11,000 pounds of solids is fed to the cattle without further drying. The thin stillage that leaves the screen and press contains 7,300 pounds of distiller's solubles and 171,300 pounds $(20,050$ gallons $)$ of water per day. The stillage will receive treatment through an anaerobic digester before final disposal in a drainfield system or irrigation system.

Based on the above mass balances and assuming a 347-days-peryear production schedule, approximately 1 million gallons of alcohol will be produced annually. It is assumed that the carbon dioxide is not collected, although this may be advantageous after a local market is identified. 


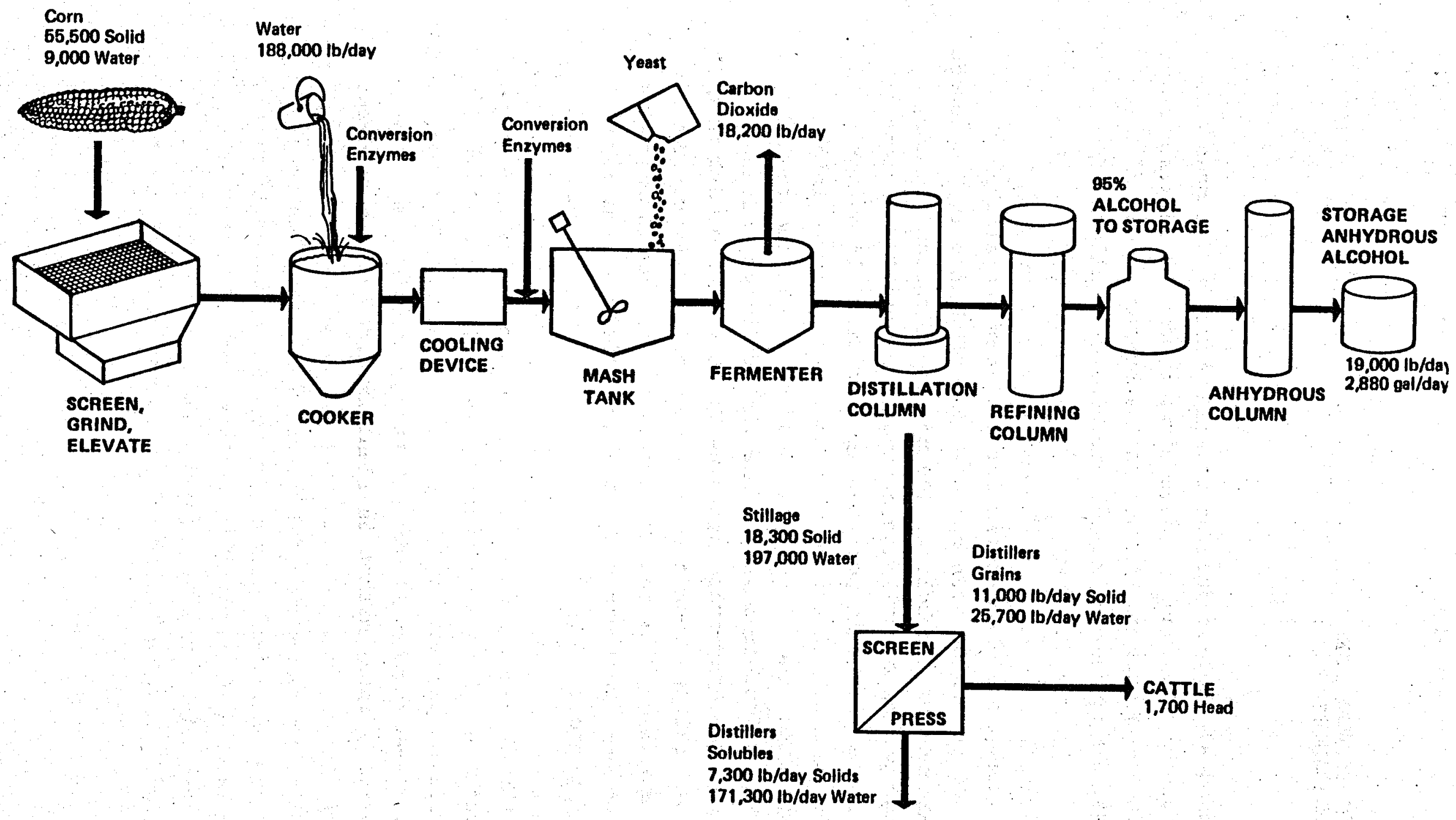

FIGURE 2 PROCESS MASS BALANCE 
The energy requirements to drive a process can be described by the quantity of energy required (Btu/unit) and the quality of that energy (temperature). The proposed project will use low pressure (25 psig) steam to provide the process energy. The steam will be generated in a boiler which will burn both biogas, a methane-carbon dioxide mixture produced in an anaerobic digester, and fuel oil.

\section{PROCESS ENERGY REQUIREMENTS}

Figure 3 shows the material and energy balance to produce 1 gallon of alcohol in a typical atmospheric alcohol production scheme which uses a conventional distillation system. In the figure, no energy recycle is assumed and a methane digester to treat the distillers solubles and produce methane is included. As seen in the figure, energy is added to the system in heat exchangers $1,2,4$, and 7 ; the reboiler; and the grain dryer. Energy is removed from the system in heat exchangers $3,5,6,8$, and 9 . Additional energy is obtained from the system in the form of methane produced by the methane digester. This energy balance is summarized in Table 1.

Assuming no energy recycle, 58,185 Btu are required to produce 1 gallon of alcohol. However, 20,437 Btu are removed from the system and are potentially available for reuse. Using cold $\left(60^{\circ} \mathrm{F}\right)$ water to $\operatorname{cool}$ the mash in heat exchanger No. 5 and then using the same water to cool the mash in heat exchanger No, 3 will provide over 90 percent of $170^{\circ} \mathrm{F}$ water for the slurry and conversion tank, thus saving $9,037 \mathrm{Btu}$. The spent beer leaving the stripping column at $235^{\circ} \mathrm{F}$ can be 


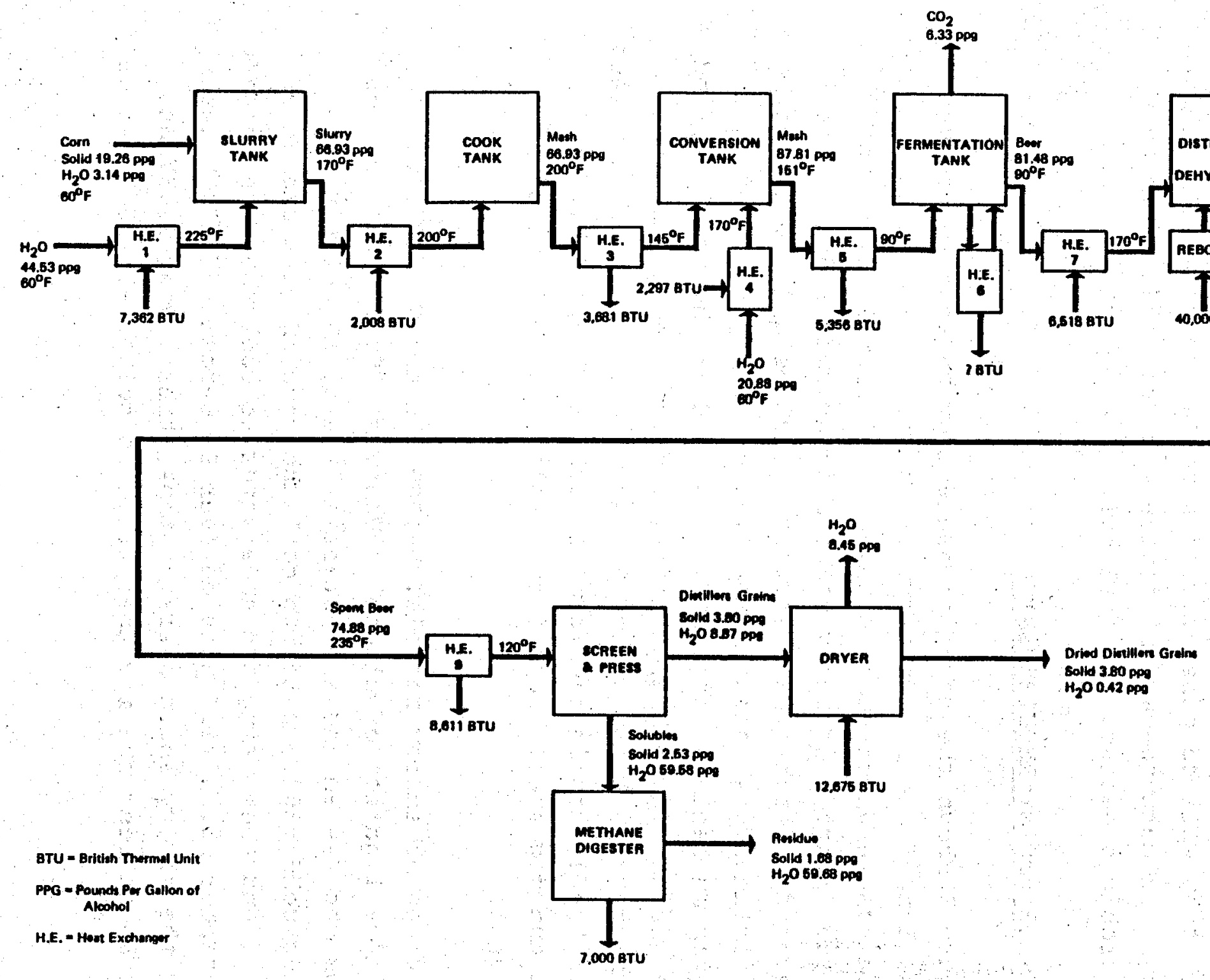

FIGURE 3

PROCESS ENERGY BALANCE

C.. 
Table 1

ALCOEOL PROCESS THERMAL REQUIREMENTS

Elow $1 \mathrm{~b}$.

Device $^{\mathrm{a}}$

H.E. $1^{\text {b }}$

H.E. 2

E.E. 3

H.E. 4

E.E. 5

H.E. 6

H.E. 7

Reboiler

E.E. 8

H.E. 9

Methane

Digester

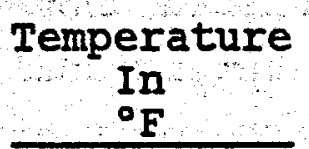

60

170

200

60

151

60

90

81.48

6.6

74.88
Temperature out

${ }^{\circ} \mathrm{F}$

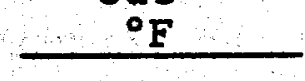

225

200

145

170

90

84

170

100

120
Btu Per Gallon

Alcohol

$+7,362$

$+2,008$

$-3,681$

$+2,297$

$-5,356$

undetermined

$+6,518$

$+40,000$

$-2,842$

$-8,558$

$-7,000$

aefer to figure 3 for the process location and function of each device.

$\mathrm{b}_{\mathrm{H} . \mathrm{E} .}$ = heat exchanger 
used to heat the slurry entering the cook tank to $200^{\circ} \mathrm{F}$, and then be used again to preheat the beer in heat exchanger No. 7 to $170^{\circ} \mathrm{F}$. This energy reuse will save $8,526 \mathrm{Btu}$. The energy reuse schemes described above will save a total of 17,565 Btu, leaving the conventional distillation energy, $40,000 \mathrm{Btu}$, as virtually the only energy requirements to produce the alcohol.

The energy removed from the fermentation tank to maintain a $90^{\circ} \mathrm{F}$ operating temperature will vary with the ambient conditions. The cooling water used to maintain this operating temperature will enter the fermenter at $60^{\circ} \mathrm{F}$ and exit at $80^{\circ} \mathrm{F}$. Heat exchanger No. 6 will cool this water from $80^{\circ} \mathrm{F}$ to $60^{\circ} \mathrm{F}$ for reuse in the fermenter. It is doubtful that this energy, the quantity of which is undetermined, will be useful due to its low temperature range.

Recently, distillation systems which use vapor recompression to reduce distillation energy requirements have been developed. While these systems have been quoted at a wide range of energy savings, a conservative estimate is that the distillation thermal energy requirements can be reduced to approximately 18,000 Btu per gallon of alcohol produced. Assuming the energy reuse schemes described above, vapor recompression distillation, and allowing no credit for methane generation, the total energy required to produce a gallon of alcohol is approximately $18,000 \mathrm{Btu}$. The application of the energy derived from methane digestion could potentially reduce the total energy requirements to $11,000 \mathrm{Btu}$.

The above discussion indicates that the energy requirements to produce 1 gallon of alcohol can range from 58,000 to $11,000 \mathrm{Btu}$, depending upon the level of energy recycle and reuse. For this study, 30,000 Btu per gallon of alcohol 
produced is assumed for the process energy requirements. This energy is supplied in the form of low pressure (15 psig) steam.

\section{THERMAL ENERGY SYSTEM}

As indicated in the above discussion, the anaerobic digestion of the distiller's solubles contained in the thin stillage will provide approximately 7000 Btu of the 30,000 Btu required to produce a gallon of anhydrous alcohol. As will be seen in following sections, the anaerobic digestion of the manure produced by the cattle onsite will provide an additional 7000 Btu per gallon of alcohol produced. The remaining 16,000 Btu required to produce 1 gallon of alcohol will be provided by fuel oil.

Therefore, the anaerobic digestion system will provide over 45 percent of the energy required to produce the alcohol. In the event that the rather low energy requirements presented by some process vendors are factual, this percentage could be significantly higher. 
Currently, there are numerous state and Federal tax incentives to support and encourage the development of alcohol fuels. Two Idaho state laws which could potentially impact the proposed project include the following:

- Senate Bill 1245 provides that 50 percent of the claims made against the Motor Fuels Refund Account be transferred into the new Gasohol Refund Account and that any distributor of motor fuels may file claims of 4 cents per gallon of gasohol sold against the Gasohol Refund Account.

- Senate Bill 1247 allows a property tax credit for any personal property or improvement used or constructed to manufacture alcohol for use in gasohol.

Full provisions of the above laws are located in Appendix A (page 25).

Federal tax incentives supporting fuel alcohol production include the following:

- The Energy Tax Act of 1978 exempts alcohol-gasoline blends from the 4-cents-per-gallon Federal motor fuel excise taxes. The Windfall Profit Tax Act extends this exemption through 1992 and provides for a tax refund for the excise paid on any gasoline which was subsequently used to blend gasohol. See page 4 in the Appendix for further details. 
- The Windfall Profit Tax Act provides for a 40-centsper-gallon alcohol tax credit for a blender of gasohol. However, this tax credit is reduced by the amount of Federal excise tax exemption applicable to the blended fuel. For further details, see page 5 in the Appendix.

- The Windfall profit Tax Act extends the provision of the Energy Tax Act of 1978 which allows a 20 percent investment tax credit to be applied to fuel alcohol plants. For further details, see page 10 in the Appendix.

- The Economic Regulatory Administration amends the Crude Oil Entitlements Program to allow entitlements to be granted to certain petroleum substitutes including fuel alcohol. The entitlements earned by eligible firms are equivalent, on a Btu basis, to the entitlements earned on uncontrolled crude oil (i.e., approximately 5 cents per gallon of alcohol at current entitlement levels). For further details, see page 19 in the Appendix.

- The Windfall Profit Tax Act simplifies the statutory and regulatory requirements to obtain a permit for operation from the Bureau of Alcohol, Tobacco, and Firearms. For details, see page 20 in the Appendix.

It should be noted that the way these various tax credits interface with each other is complex, and a competent tax lawyer should be consulted to determine how they may impact an individual's tax position. 
The major design criteria for an anaerobic digester are the temperature of operation and the solids loading rate.

Anaerobic fermentation has two temperature ranges at which different bacteria operate most efficiently. Mesophilic operation has an optimum temperature of $97^{\circ} \mathrm{F}$ and requires approximately a 15-day digestion period, while thermophilic operation is optimized at $135^{\circ} \mathrm{F}$ and requires about a 10-day digestion period. Although the thermophilic operation requires a much smaller digester, this process is less stable than the mesophilic operation. It is also likely that the lower temperature range of mesophilic digestion will be more readily maintained by the geothermal water. In addition, the nutritional value of mesophilic digester residue is greater than thermophilic digester residue. For these reasons, the anaerobic digesters were designed for mesophilic operation.

It is anticipated that all of the energy necessary to maintain the digester at $90^{\circ} \mathrm{F}$ will be supplied by geothermal water. Assuming a $130^{\circ} \mathrm{F}$ source, a $20^{\circ}$ temperature drop, and a flow of 100 gallons per minute, a geothermal source could supply approximately 1 million Btu per hour to the digesters. While a detailed energy balance was not calculated for this study since actual geothermal source temperature data are unavailable, studies for similar systems indicate that a system, as described above, should be more than adequate for the proposed application. 
The digester loading rate is a major criterion for determining the size of a bioconversion plant. The design loading rate for the proposed plant is 0.20 pound of volatile solids per day for each cubic foot of digester volume. Although studies have indicated the feasibility of loading from 0.1 to 0.4 pounds of organic material per cubic foot, digester operation is more sensitive at higher loadings and the chance of upsetting the digesters and interrupting the digestion process is increased. 
BIOGAS

PROCESS DESCRIPTION

A bioconversion facility serving 1,700 head of cattle will be capable of processing 15,000 pounds of wet manure per day. The manure is composed of dissolved solids, suspended solids, and water. In addition, the facility will process approximately 21,000 gallons of thin stillage each day which contains 7,000 pounds of distiller's solubles.

The manure and stillage will first be mixed with water and/or centrate recycle to produce a mixture which is approximately 6 percent solids. This mixture is continuously fed to the digesters, where heat and bacteria will destroy nearly half of the volatile solids and produce methane and carbon dioxide (biogas). This process also produces a trace of hydrogen sulfide which exits with the biogas.

The biogas has a heating value of approximately 600 Btu per cubic foot under standard conditions and may be burned directly or treated to remove the hydrogen sulfide. The biogas can also be treated to remove a portion of the carbon dioxide, which increases the unit heating value. It is anticipated that no gas treatment will be required for the proposed project.

The effluent is pumped from the digesters to a centrifuge where the concentration of residue is increased to approximately 25 percent solids. This high-solids residue can be mixed with other feeds and fed directly to the cattle or dried and stored for future use. The average detention time for the manure in the digester is 20 days. 
Raw manure from the feedlot will be transported to the raw manure preparation and mixing basin area as the pens are cleaned periodically. Front-end loaders will load raw manure from the storage pile into a loading hopper. A clump breaker mechanism at the bottom of the hopper will break up large clumps of manure before they enter the screw feeder. Water under high pressure will further break up the manure and wash it into the screw feeder. The screw feeder mixes and feeds the manure and water together into the grit chamber where large rocks, gravel, etc., are collected and removed periodically. The manure slurry is then passed through the comminutor channel where the solids are cut up and reduced to a smaller uniform size. From the comminutor channel, the manure slurry enters the mixing basin. The mixing basin is essentially a large wet pit where stillage and water are added to further reduce the mixture to approximately 6 percent solids. Mixing in the basin is accomplished by air blowers and aeration type mixing tubes. From the mixing basin, the manure slurry is pumped to the anaerobic digesters.

\section{ANAEROBIC DIGESTERS, GASEOLDER TANK, AND DEGAS COLUMN}

Two anaerobic digesters of equal size were selected for this facility. The sludge digestion for each digester is carried out as a continuous single-stage process. The digesters are made of prestressed concrete with fixed concrete covers. The sluage is mixed by gas recirculation through bubble draft tube type mixers. A hot water jacket around each 
draft tube allows the sludge to be heated as the sludge rises up through the tube. The gas, as it is formed, is piped off to either the gasholder tank or flared. The gasholder tank provides some gas storage and allowance for volumetric changes in the digesters. The digested sludge is drawn off and pumped to the degas column where entrained gas is removed from the sludge. The sludge is then pumped to the dewatering centrifuges.

\section{CENTRIFUGES, SLUDGE BUNRER, AND CENTRATE LAGOON}

Two solid bowl centrifuges will be used to dewater and thicken the sludge to approximately 25 percent solids. The sludge is fed at a constant flow rate into the centrifuge where it separates into a cake containing most of the solids and a liquid stream called centrate. The cake, which contains approximately 75 percent moisture, is discharged from the centrifuge onto a belt conveyor where it is carried to a sludge bunker outside the centrifuge building. From the sludge bunker, the sludge is fed by screw conveyor to dump trucks where it is transported either to the feeding station or sludge storage beds. The centrate flows from the centrifuge into a wet well where it is either pumped to the wastewater disposal system or recycled to the mixing basin as described above. 
The biogas yield from the conversion process is based on the amount of volatile solids in the manure and stillage which enters the digesters. Samples taken from pilot studies by CH2M HILL for the Lamar Company Plant ${ }^{1}$ indicate the manure will be comprised of 43.30 percent volatile solids, 21.35 percent nonvolatile solids, and 35.35 percent water. Data from process vendors indicate that approximately 78 percent of stillage solids is volatile solids.

Approximately 12,900 gallons of water are mixed with 14,900 pounds of manure and 20,300 gallons of thin stillage daily to produce the desired solids concentration. This mixture is fed to the digester where about 41 percent of the volatile solids is destroyed in the digestion process to produce methane $\left(42,600 \mathrm{ft}^{3} / \mathrm{day}\right)$, carbon dioxide $\left(29,300 \mathrm{ft}^{3} / \mathrm{day}\right)$, and a small amount of hydrogen sulfide. This gas production rate is equivalent to $3.54 \mathrm{ft}^{3}$ of methane and $2.29 \mathrm{ft}^{3}$ of carbon dioxide per pound of volatile solids added to the digester per day.

The digester effluent is then pumped to a centrifuge where 37,100 pounds of residue are separated from 34,400 gallons of centrate per day. A portion of the centrate can be pumped back to the mixing basin for reuse. The remaining makeup water to the mixing basin is provided by the geothermal and fresh water. The residue is either directly utilized as a portion of the cattle feed ration or stored.

I Bio-Gas of Colorado, Inc. Energy Potential Through BioConversion of Agricultural Wastes. Final Report to Four Corners Regional Commission. Demonstration Project FERC No. 672-366-002. October 1977. $91 \mathrm{p}$. 
A preliminary mass balance design for a 1,700-head manure processing facility is shown on Figure 4. 


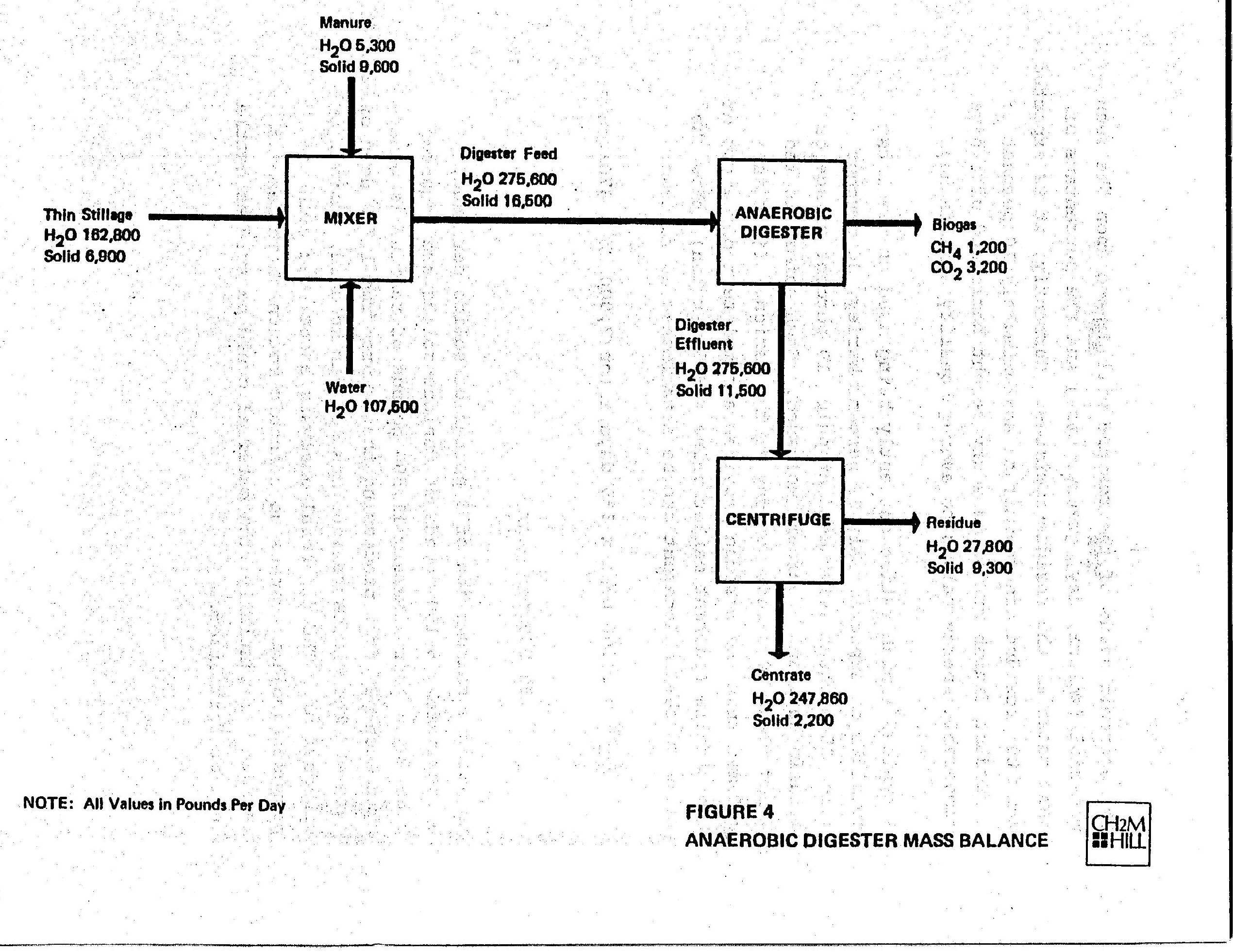


The economic value of the residue will depend upon the feed material (silage, hay, grains, etc.) and the percentage of that material the residue replaces. Currently, it is expected that the residue can constitute approximately 10 percent of a feedlot finish ration on a dry weight basis and will have comparable energy values to average quality alfalfa hay.

A typical finish ration currently being used at feedlots consists of approximately 30 percent barley, 30 percent corn, 25 percent molasses beet pulp, 10 percent silage or alfalfa hay, and 5 percent molasses. Each animal is fed about 28 to 30 pounds per day of the ration. If it is assumed that the residue provides a complete replacement of the alfalfa (current market value $=\$ 70$ per ton), then the value of the replacement can be established as follows:

$$
\frac{31 \mathrm{~b}}{\text { day }} \times 1,700 \text { head } \times 365 \text { days } \times \text { ton } / 2,0001 \mathrm{~b} \times \$ 70 / \text { ton }=
$$

$\$ 65,000$ per year

Assuming a consumption of 3 pounds of solids per head, approximately 5,100 pounds of residue solids are required each day. Approximately 11,500 pounds of residue is generated each day from processing the manure from 1,700 head of cattle. The excess residue must either be sold, stored, or disposed of. The financial analysis associated with the proposed project assumes no economic return on the excess residue. Potentially, the material could be sold as cattle feed or fertilizer. 
The centrifuge residue is a protein-rich mixture composed of approximately 25 percent dry matter and 75 percent moisture. on a dry basis, this residue contains about 18 percent protein, as shown in Table 2 , and has proven value as a cattle feed supplement. Various studies, 1,2 through actual feeding trials, have shown the feasibility of using digested cattle manure as a successful replacement for such feeds as cottonseed meal, barley, and high-grade alfalfa hay.

Table 2

ANAEROBIC DIGESTER RESIDUE

(Centrifuged Digester Cake)

Moisture

Dry Matter

Dry Basis:

Protein

Calcium

Phosphorus

Fat

Fiber

Ash
76.62

23.38

18.15

4.20

.85

3.52

15.29

36.44

Iio-Gas of Colorado, Inc. Energy Potential Through BioConversion of Agricultural Wastes. Final Report to Four Corners Regional Commission. Demonstration Project FERC No. 672-366-002. October 1977. $91 \mathrm{p}$.

${ }^{2}$ Prokop, Mike. Refeeding Value of solids from Methane Generators: A Bonanza??? Summary Report to National Cattlemen's Association Environmental Management Committee. San Diego, California. January 22, 1980, $14 \mathrm{p}$. 
Table 3 shows the breakdown of the capital cost for the proposed facility which integrates an alcohol plant, cattle feedlot, anaerobic digester, and geothermal well. The general alcohol process equipment, including the grain proparation system, saccharification, fermentation, distillation and dehydration system, costs approximately $\$ 1,320,000$. All components of this system exposed to corrosive conditions are constructed of stainless steel.

The system is thoroughly instrumented and computer controlled in order to improve system operation and reduce labor costs. This instrumentation package is estimated to cost approximately $\$ 125,000$.

It is estimated that a building 30 feet high and containing 9,000 square feet will be required to house the alcohol facility. Based upon these figures and assuming a cost of $\$ 30$ per square foot, the building cost is estimated at $\$ 270,000$

Sufficient storage is provided to store the anhydrous alcohol and associated distiller's grain for 10 days. The cost for these storage facilities is approximately $\$ 60,000$.

It was assumed that a 2,000-foot well would produce adequate quantities of $130^{\circ} \mathrm{F}$ water to supply the necessary energy for the anaerobic aigesters. The cost of an 8-inch well was estimated at $\$ 175,000$.

A turnkey anaerobic digester system, which includes the aigesters, centrifuge, pumps, piping, mixing station, electrical, and instrumentation, was estimated to cost $\$ 800,000$. 
Table 3

CAPITAL COSTS

Grain Preparation

september 1980

cost

Saccharification and Fermentation

$\$ \quad 60,000$

Distillation and Dehydration system

500,000

760,000

Instrumentation

125,000

Building ( 9000 S.F. @ \$30/S.F.)

270,000

Boiler

100,000

Alcohol and DDG storage

60,000

site work and utilities

200,000

Geothermal Well (2,000 ft)

175,000

Waste Disposal

100,000

Anaerobic Digester System

800,000

subtotal

$\$ 3,150,000$

Construction contingencies (15\%)

470,000

Total Construction cost

$\$ 3,620,000$

Engineering \& Aaministration (10\%)

360,000

Total Project cost

$\$ 3,980,000$

The cost of a waste disposal system for this facility, which consists essentially of land application, was estimated at $\$ 100,000$.

The cost for the site work and utilities is difficult to estimate since the necessary geographical and soils information is unavailable. A cost for this type of facility could be expected to average approximately $\$ 100,000$. 
Totaling the above costs results in a subtotal of $\$ 3,150,000$. Construction contingencies (included at 15 percent) and engineering and administrative costs (assumed at 10 percent) have been added to the cost estimate to produce a total project cost of $\$ 3,980,000$.

Cost estimates in studies of this type are normally classified as order-of-magnitude estimates. The estimates carry an accuracy range of +50 percent to -30 percent. That is, the actual construction cost of the project, if it is constructed in 1980, could vary from 50 percent more to 30 percent less than the initial order-of-magnitude estimate. The quality of the project desired and the method of construction chosen will have the largest impact on the final project cost. 
LEGAL IMPLICATIONS OF USING DIGESTER RESIDUE

FOR CATTLE FEED

The regeneration of cattle feed by anaerobic digestion of manure provides a major economic benefit for the proposed project. However, the legal implications of feeding residue material to cattle have recently been subject to questions and confusion. state, regional, and national FDA officials and numerous state Feed Control officers were contacted to resolve this issue.

The Feed Control officers for the states of Idaho, oregon, Washington, Colorado, and Utah were contacted to determine the current status of state regulations for registering animal waste feeds. While only colorado had animal wastes registered as feeds, all of the states have regulations in place to allow such registration. Regulations for Colorado and oregon are included in Appendix B.

A majority of the state Feed Control officers belong to the American Association of Feed Control officers (AAFCO). While this organization has no legal status, its recommendations are usually followed by the states. A future meeting is planned between the AAFCO and the American Feed Management Association (AFMA). It is anticipated that a standard set of regulations for registering animal wastes as feeds will be developed at this meeting and that these regulations will be adopted by all of the states. This standardization of regulations will facilitate the registration process by allowing the required test data to be applicable in all states. 
The only state requirement for interstate shipment of animal waste feeds or cattle that have been fed these materials is that the feed be registered in both states. However, the interstate shipment of feed or cattle is subject to FDA inspection and approval. Discussions with numerous FDA officials indicate that current FDA policy does not sanction feeding any animal wastes to animals that will be used for human consumption. These officials indicate, however, that because the preponderance of feeding study data show animal wastes to be a viable and economic animal feed, this restriction is in the process of being lifted. It is anticipated that the necessary requirements for lifting the restriction will be completed within the near future. Once the restriction is lifted, animal waste feeds and cattle fed with these materials will only be subject to the normal EDA inspection. That is, if the animals or feeds are inspected and found to be adulterated with heavy metals, pesticides, etc., they will be subject to the same rules and regulations that apply to contaminated conventional feed materials. The animal waste feeds must be thoroughly tested before state registration, reducing the likelihood that FDA inspection of registered material will be a problem for the cattle feeder. 
INTEGRATED OPERATION

The previous sections of this report discussed the operation of the alcohol and biogas facility separately. In reality, these facilities will be closely integrated with each other and with the geothermal resource and cattle feedlot. Figure 5 shows a diagram of how these facilities will integrate with each other and indicates the yearly mass balance for the various flow streams.

Corn will be used in the alcohol plant to produce anhydrous alcohol. Unless local markets are identified, the carbon dioxide produced will be wasted. A byproduct of the alcohol production process, distiller's dried grain (DDG) will be used as cattle feed. The distiller's solubles contained in the thin stillage will be pumped to the anaerobic digester where it will combine with the manure from the feedlot to produce biogas which will help provide the energy for the alcohol process. A portion of the digester residue will be dewatered and used as cattle feed. The remaining residue can be sold as feed or used as fertilizers. The energy required to maintain proper operating temperature in the anaerobic digester will be provided by geothermal water.

The major advantage associated with the above system is the reduced energy requirements for producing the fuel alcohol and DDG. The ability to feed the DDG wet reduces the energy requirements for the alcohol facility by approximately 30 percent. In addition, the biogas facility provided approximately 45 percent of the remaining required energy. These savings total approximately 63 percent over a conventional alcohol facility. 


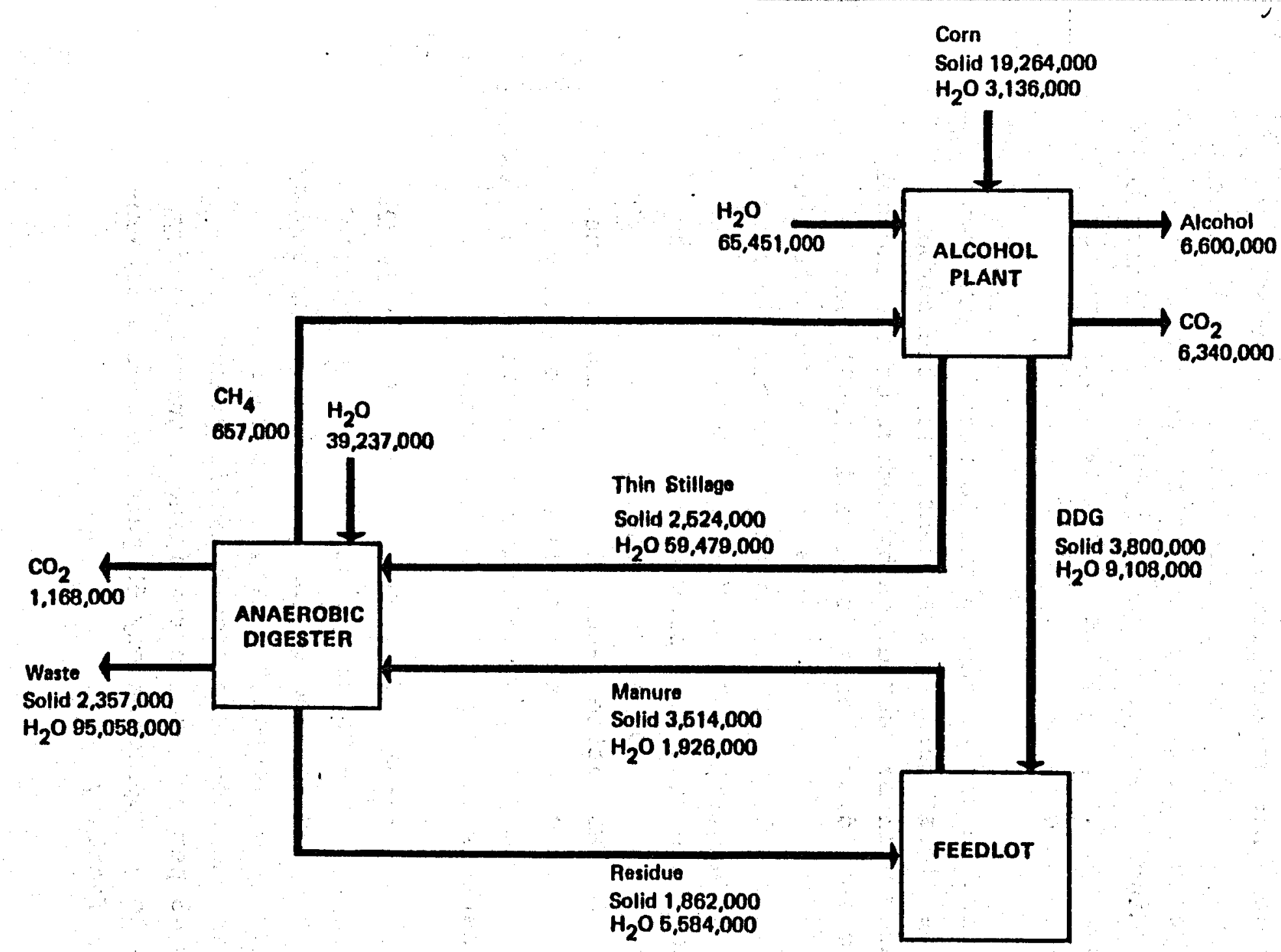

NOTE: All Values in Pounds Per Year

FIGURE 5

INTEGRATED OPERATION 
Table 4 shows a breakdown of the estimated yearly operating costs in 1980 dollars for the proposed alcohol plant.

\section{Table 4 \\ ALCOHOL PLANT OPERATING COST \\ (1980 prices)}

Labor

Feedstock

Enzymes and Chemicals

Repairs and Maintenance

Insurance

Utilities

Fuel oil

Electricity

Other

TOTAL

\begin{tabular}{rr}
\multicolumn{1}{|c}{$/ \mathrm{yr}$} & $\frac{\phi / g a l}{20.0}$ \\
\hline$\$ 200,000$ & 20.0 \\
$1,232,000$ & 123.2 \\
185,000 & 18.5 \\
50,000 & 5.0 \\
50,000 & 5.0 \\
& \\
130,000 & 13.0 \\
63,000 & 6.3 \\
10,000 & 1.0 \\
\hline$\$ 1,920,000$ & 192.0 \\
&
\end{tabular}

\section{LABOR}

Labor costs assume a four-shift operation. One shift will use three men for production, while the remaining three shifts will use two men per shift. The salary of the above personnel is assumed to be $\$ 12,000$ per year. One secretary/ bookkeeper is also included at a salary of $\$ 12,000$ per year. It is assumed that a plant superintendent will receive an annual salary of $\$ 20,000$. All of the above labor costs are increased by 20 percent to cover payroll taxes and fringe benefits. 
Based on the above assumptions, the annual labor costs for the alcohol production facility will be $\$ 200,400$.

\section{FEEDSTOCK}

Corn at a cost of $\$ 3.08$ per bushel is assumed to be the primary feedstock for the alcohol plant. Based on this price and the consumption of 400,000 bushels of corn each year, the annual cost of feedstock will be $\$ 1,232,000$.

\section{ENZYMES AND CEEMICALS}

The enzymes required for the alcohol production process include alpha-amylase, gluco-amylase, and those enzymes produced by the yeast. The first two enzymes convert the starch contained in the grain into simple sugars. The enzymes provided by the yeast convert the simple sugars into alcohol and carbon dioxide. The bulk cost for the two enzymes F.O.B. the dealer is approximately 6 cents per gallon of alcohol produced. Yeast cost is approximately 2.5 cents per gallon of alcohol produced.

The chemicals required for alcohol production include acids such as phosphoric and sulfuric acid, and bases such as ammonium hydroxide, denaturants, biocides and anti-foam agents. The requirements for these chemicals can vary, depending on the process chosen and enzymes used. However, most sources indicate that the requirements for these materials average approximately 10 cents per gallon of alcohol produced.

Based on the above data, the total cost of enzymes and chemicals for alcohol production will be 18.5 cents per gallon of alcohol produced, or $\$ 185,000$ per year. 


\section{REPAIRS AND MAINTENANCE}

Repairs and maintenance are estimated to total $\$ 50,000$ each year for the proposed facility.

\section{UTILITIES}

Approximately $2 \mathrm{kWh}$ of electricity for pumps, motors, and lights will be required to produce a gallon of alcohol. On this basis and a power cost of $\$ .02$ per $k W h$, the yearly electric cost for these items wil1 be $\$ 40,000$.

It is assumed that the proposed facility will use thermocompression devices to reduce the process thermal requirements. As such, the study assumes that only 30,000 Btu are required to produce a gallon of alcohol as opposed to 40,000 Btu which is quoted for conventional systems. While 10,000 fewer Btu are required for the process, some additional electrical energy is required to drive the thermocompression equipment. Process vendors estimate that slightly over $1 \mathrm{kWh}$ will be required to power this equipment for each gallon of alcohol produced. Based on these data and an electrical cost of $\$ .02$ per $\mathrm{kWh}$, the electrical cost for this equipment will total approximately $\$ 23,000$ per year.

Adding the above costs results in a total annual electrical cost of $\$ 63,000$.

Fuel Oil

This study assumes that 30,000 Btu of thermal energy will be required to produce a galion of anhydrous alcohol. As previously described, the anaerobic digestion of the thin 
stillage from the alcohol plant and manure from the cattle feedlot will provide the equivalent of 14,000 Btu per gallon of alcohol produced in the form of biogas. The remaining 16,000 Btu of thermal energy will be provided by No. 2 fuel oil. Assuming a cost of $\$ .875$ per gallon of fuel oil and a boiler efficiency of 75 percent, the annual cost of oil is approximately $\$ 130,000$.

Other

An allowance of $\$ 10,000$ has been included for miscellaneous utilities such as telephone, water, and domestic sewage.

\section{Insurance}

Insurance is estimated on the basis of 1.5 percent of equipment costs. On this basis, insurance will cost approximately $\$ 50,000$ per year.

Summing the above operating and maintenance costs results in an annual cost of $\$ 1,920,000$ for the 1 million gallon per year facility. 
REVENUE

The proposed plant will produce 1 million gallons of anhydrous alcohol each year. At the current selling price of $\$ 1.80$ per galion, the annual revenue from alcohol sales will be $\$ 1,800,000$.

Distiller's dried grain (DDG), a byproduct of grain based alcohol production, is a valuable commodity and contributed significantly to the profitability of the proposed project. While the feed value of DDG is unquestioned, the selling price is subject to debate. For this study, it is assumed that DDG sells for the same price as the feedstock, $\$ 3.08$ per bushel. Based on this sale price, the DDG produced by the alcohol plant will be valued at $\$ 232,000$.

This study assumes that 3 pounds of digester residue is fed to each cow per day. Substituting the residue for alfalfa hay valued at $\$ 70$ per ton, the residue produces an annual revenue of $\$ 65,000$.

Based on the above assumptions, the total annual revenue of the proposed project will be $\$ 2,097,000$

\section{SIMPLE PAYBACK ON INTEGRATED FACILITY}

Payback period is defined as the minimum length of time theoretically necessary to recover the original capital investment in the form of cash flow to the project, based on total income minus all costs except depreciation. The maximum acceptable payback period is dependent upon the alternatives and risks as defined by the investor. 
The operating and maintenance costs associated with the proposed project total approximately $\$ 1,920,000$. Subtracting this cost from the anticipated revenue results in a gross profit of $\$ 177,000$. Dividing the gross profit into the project cost, which is $\$ 3,980,000$, results in a simple payback of 22.5 years. All of the above data is summarized in Table 5 .

\section{SENSITIVITY ANALYSIS ON INTEGRATED FACILITY}

The previous simple payback analysis was calculated using the best available data at this time. However, grain commodities markets can be quite unstable. Small changes in the feedstock costs can significantly affect the economics of the proposed project since that cost is approximately 65 percent of the total operating cost. Also, the value of dried distiller's grain is subject to question and may vary significantly from the value presented in the analysis. The selling price of anhydrous alcohol is currently $\$ 1.80$ per gallon. Undoubtedly, this price will increase in the future.

In order to examine the effects that changes in the costs of these items might have on the proposed project, a sensitivity analysis was performed. In this analysis, corn was allowed to vary between $\$ 2.58$ and $\$ 3.58$ per bushel which is a $\$ .50$ deviation from the previous analysis. Distiller's dried grain was allowed to vary over the same range as the corn. Because it is very doubtful that the price of alcohol will drop in the future, this price ranged from the current $\$ 1.80$ to $\$ 2.20$ per gallon. The sensitivity of alfalfa costs was considered insignificant and, therefore, was not included in this analysis. Table 6 shows the cases that were studied. For each case, the operating cost, revenue, operating profit, and simple payback were calculated. 


\section{Revenue}

Alcohol

DDG Income

Residue Income

Total Revenue

Operating and Maintenance

Gross Profit

$\$ 1,800,000$

232,000

65,000

$2,097,000$

$1,920,000$

177,000

Project Capital cost

$\$ 3,980,000$

Simple Payback

$22.5 \mathrm{yr}$. 
Table 6

PROJECT SENSITIVITY ANALYSIS ON SIMPLE PAYBACK

\begin{tabular}{|c|c|c|c|c|c|c|c|c|c|}
\hline Feedstock Cost (\$/bu) & 3.08 & 2.58 & 2.58 & 2.58 & 2.58 & 3.58 & 3.58 & 3.58 & 3.58 \\
\hline Alcohol (\$/gal) & 1.80 & 1.80 & 2.20 & 2.20 & 1.80 & 1.80 & 1.80 & 2.20 & 2.20 \\
\hline DDG Sale Price $(\$ / b u)$ & 3.08 & 2.58 & 2.58 & 3.58 & 3.58 & 2.58 & 3.58 & 2.58 & 3.58 \\
\hline O\&M Cost (thousands) & 1920 & 1720 & 1720 & 1720 & 1720 & 2120 & 2120 & 2120 & 2120 \\
\hline Alcohol Revenue (thousands) & 1800 & 1800 & 2200 & 2200 & 1800 & 1800 & 1800 & 2200 & 2200 \\
\hline DDG Revenue (thousands) & 232 & 194 & 194 & 270 & 270 & 194 & 270 & 194 & 270 \\
\hline Residue Revenue (thousands) & 65 & 65 & 65 & 65 & 65 & 65 & 65 & 65 & 65 \\
\hline Operating Profit (thousands) & 177 & 339 & 739 & 815 & 415 & (61) & 15 & 339 & 418 \\
\hline Simple Payback (years)* & 22.5 & 11.7 & 5.4 & 4.9 & 9.6 & & 265.3 & 11.7 & 9.6 \\
\hline
\end{tabular}

太Based on a project capital cost of $\$ 3,980,000$ 
As seen in the table, the simple payback varies from 4.9 years to infinity. This wide range of payback illustrates the economic sensitivity of the project. Examination of the table indicates that a small change in the cost of corn or the selling price of alcohol produces a large change in the project's profitability. Changes in the selling price of the distiller's dried grain is not nearly as significant as changes in the other two items.

\section{SIMPLE PAYBACK ON ALCOEOL FACILITY}

In order to determine the effect of integrating an alcohol facility with a geothermaliy powered anaerobic digester system, the simple payback, for an alcohol facility without the biogas facility was calculated. The capital cost was determined by subtracting the cost of the geothermal well and anaerobic digester system from the capital cost subtotal. A construction contingency of 15 percent and engineering and administrative costs at 10 percent were added to the new subtotal. These modifications resulted in a capital cost estimate of $\$ 2,750,000$.

Because the biogas from the anaerobic digesters will not be available to supplement the alcohol process energy requirements, the fuel oil cost will increase by $\$ 114,000$, resulting in a total annual operating cost of $\$ 2,034,000$.

The revenue from the alcohol and DDG will remain unchanged, but the revenue from the digester residue will not be available. As a result, the annual revenue from the alcohol facility will be $\$ 2,032,000$.

From the above data, it is obvious that the revenue and operating costs are approximately equal, so that the alcohol 
facility by itself will never be paid off for this case. Intergrating the biogas facility with the alcohol plant improves this payback position from no payment to 22 years payback. As with the integrated facility, a sensitivity analysis could be performed to show that this project is highly sensitive to the cost of feedstock and alcohol sale price.

It should be noted that there is no absolute value which indicates an acceptable payback period. Each investment must be analyzed within the content of alternative options and the projected risk associated with the proposed investment. once the return/risk analysis is complete, a minimum acceptable payback period can be determined. 
APPENDIX A

\section{ALCOHOL FUELS}

TAX INCENTIVES 


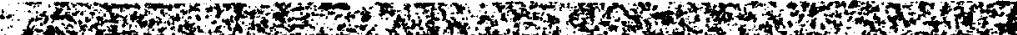

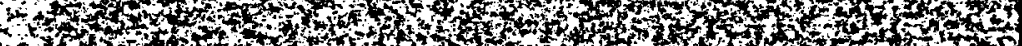

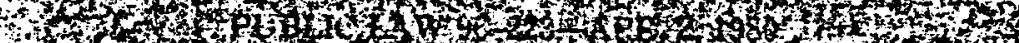

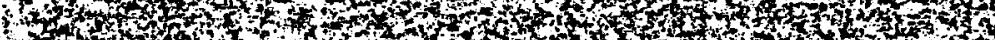

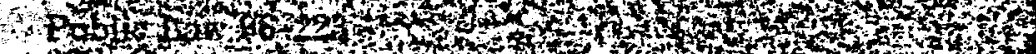

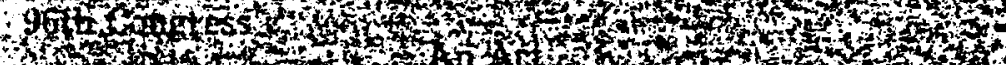

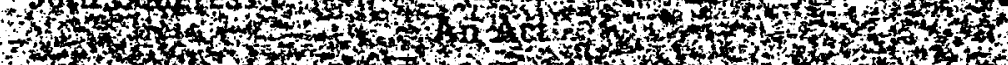

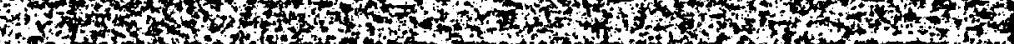

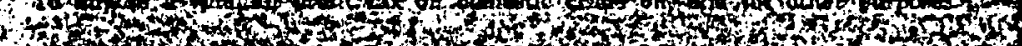

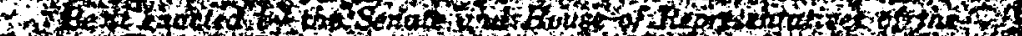

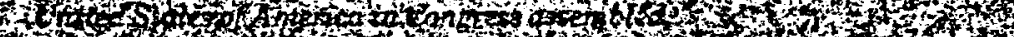

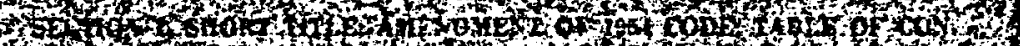

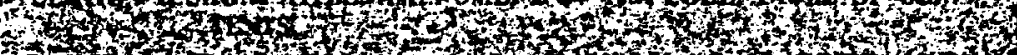

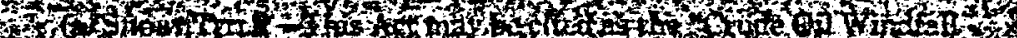

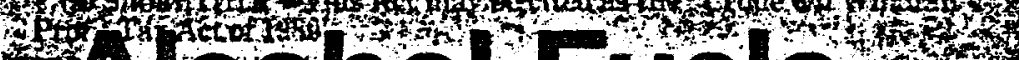
Alcohol Fuels

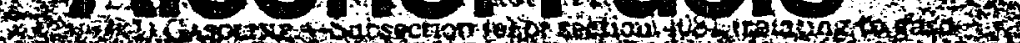

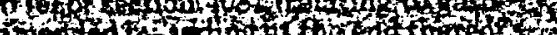

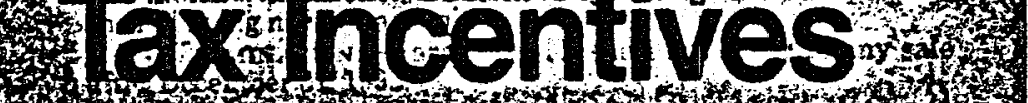

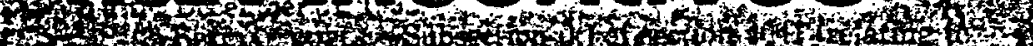

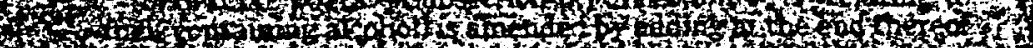
$4+40$ s

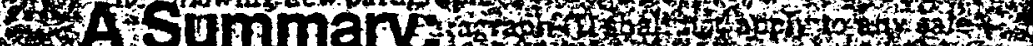

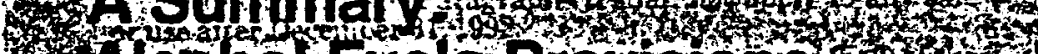

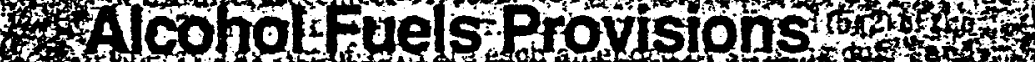

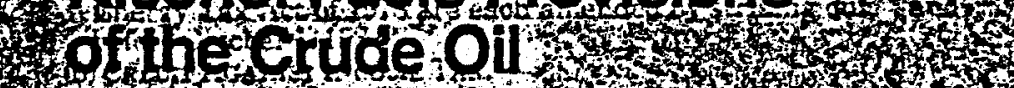

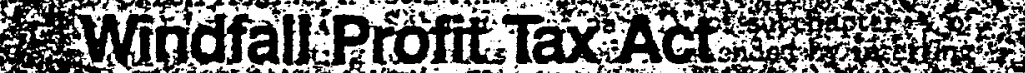

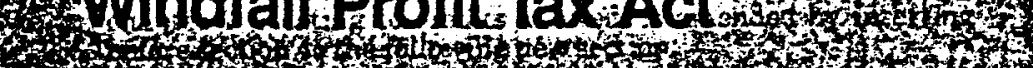

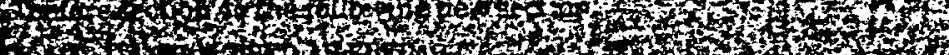

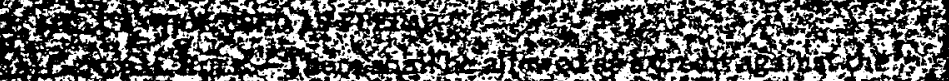

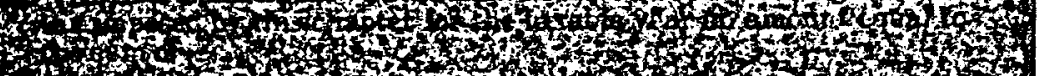

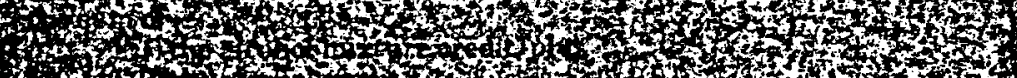

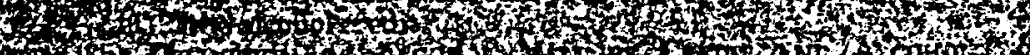

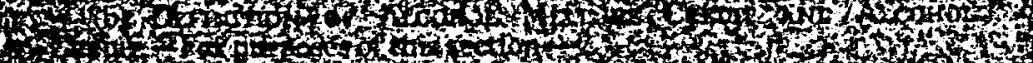

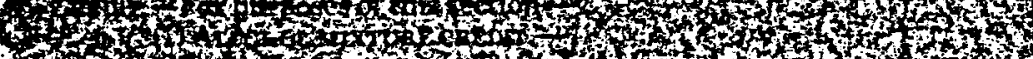

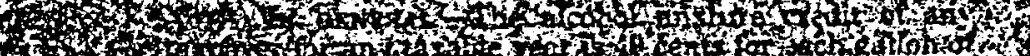

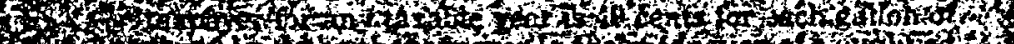

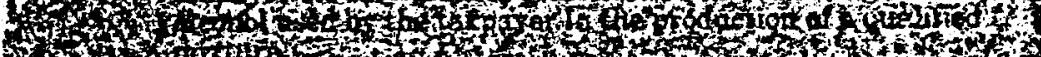

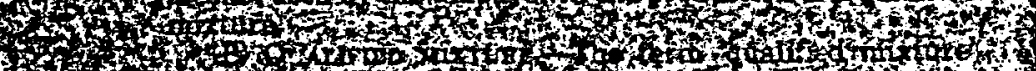

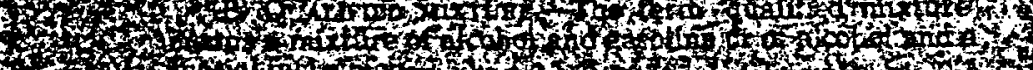

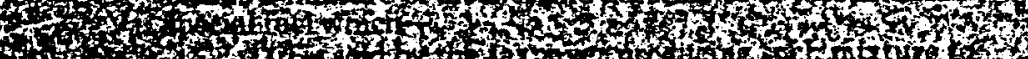

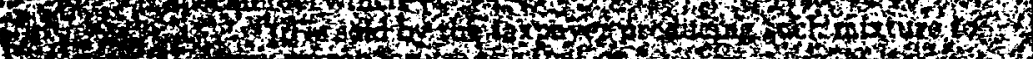

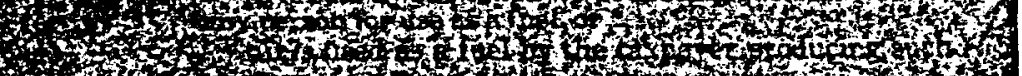

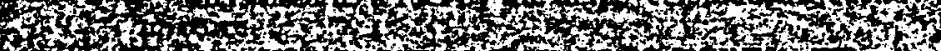

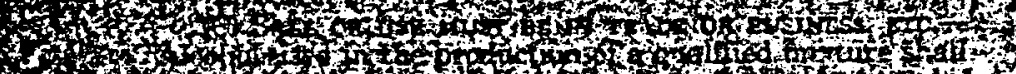

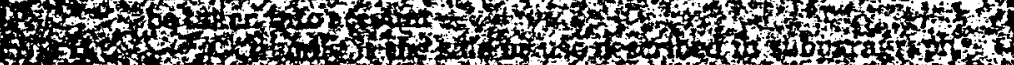

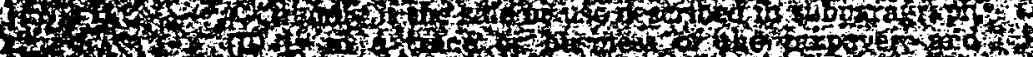

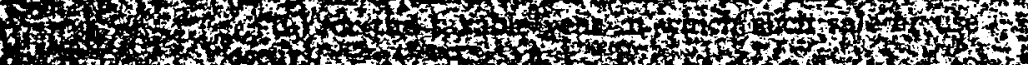

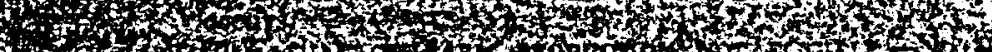
H. 40 (4)

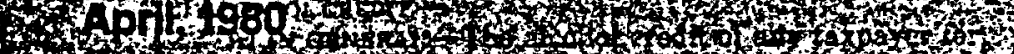

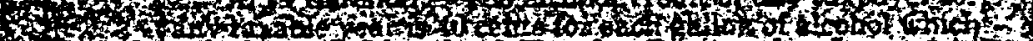

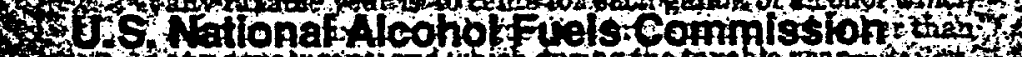

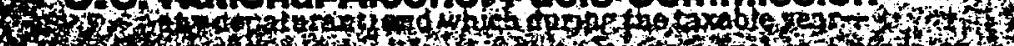

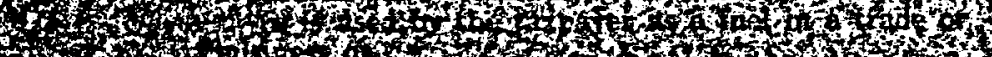

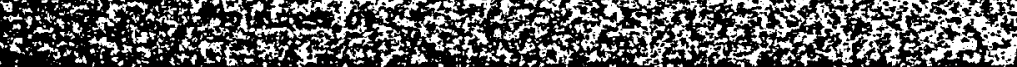




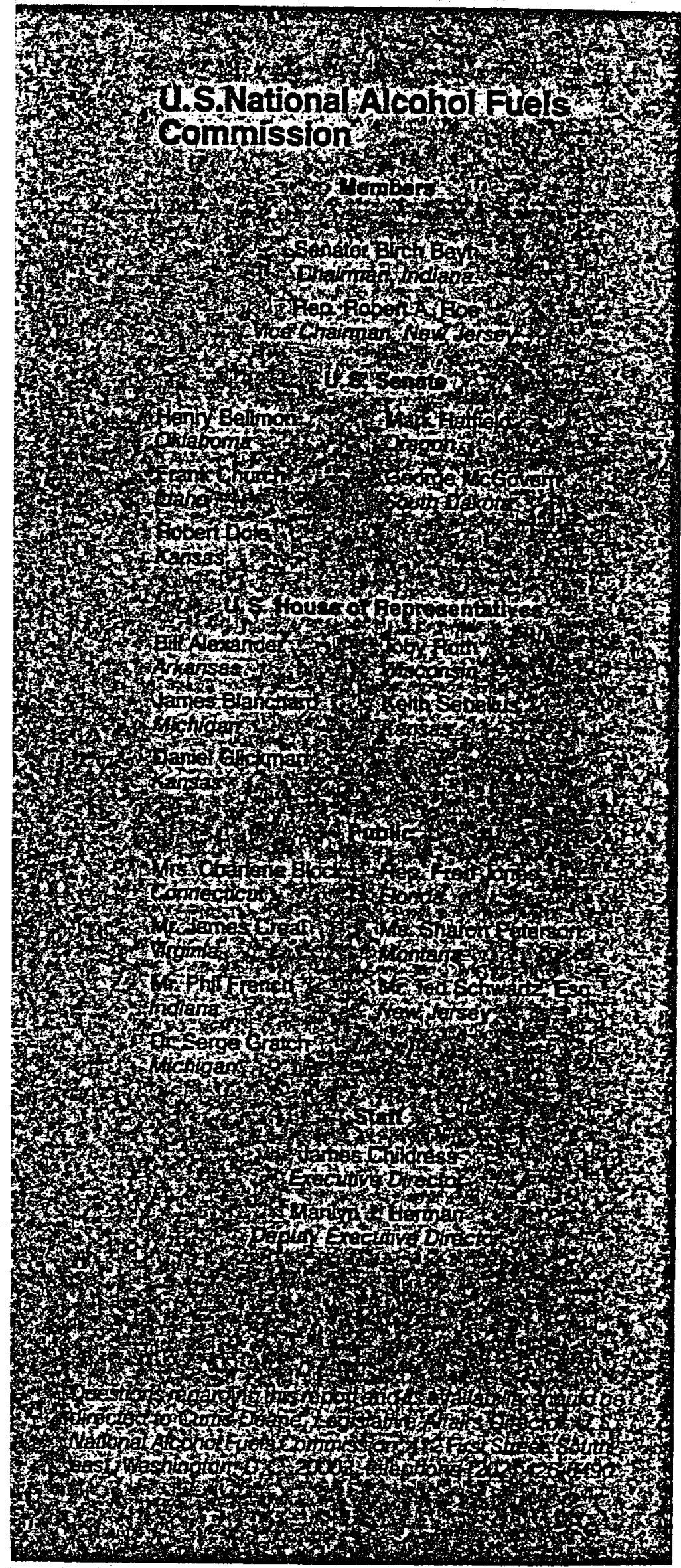

Washington, D.C. April 1980

The Crude Oil Windfall Profit Tax Act of 1980 provides significant tax incentives for producers, blenders, marketers, and users of alcohol fuels.

These incentives respond to our needs for domestic energy production in every area of the Nation. Agricultural communities and rural areas are aided through incentives to encourage alcohol fuel production on the farm, from agricultural feedstocks and other forms of biomass. Urban areas are assisted through incentives to encourage alcohol fuel production from municipal solid waste. And all Americans will be aided by alcohol fuels extending our scarce supplies of liquid fuels and reducing our reliance on imported petroleum.

However, if the Act is to achieve the goal of increased domestic alcohol fuel production, potential alcohol fuel producers and investors must become aware of these incentives. For that reason the U.S. National Alcohol Fuels Commission has prepared this summary of the alcohol fuel provisions of the Crude Oil Windfall Profit Tax Act of 1980.

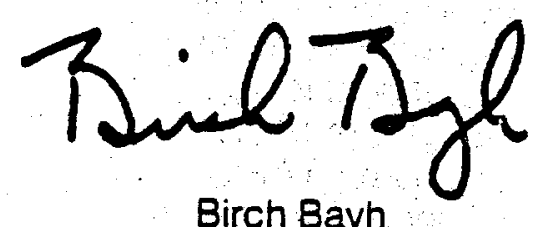

Birch Bayh

Chairman

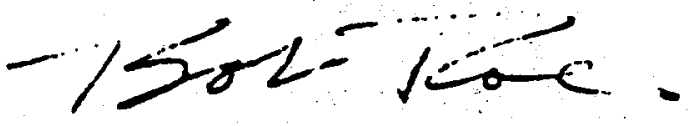

Robert A. Roe

Vice Chairman 
Table of Contents

Page

Introduction 2

Four Cent Per Gallon Excise Taxes Exemption

The Exemption

Refund of Tax on Gasoline

Blended with Alcohol

Income Tax Credits

Blended Fuels .................. 5

Straight Alcohol Fuel ............. 8

Alcohol Fuel Producer Eligibility ...... 9

Energy Investment Tax Credit for Blomass

The Credit ...................... 10

Reduction of the

Energy Investment Tax Credit

Alcohol Fuel Plant Operating Permits

Regulatory Simplification ........... 12

Small Plants ..................... 13

Tax-Exempt Bonds for Alcohol Fuel

From Solid Waste

State Financing of

Renewable Energy Property 16

Study of Imported Alcohol 17

Annual Reports on Alcohol Fuels 18 


\section{Introduction}

The Crude Oil Windfall Profit Tax Act of 1980 (Public Law 96-223) was signed into law by the President on April 2, 1980. The Act contains several provisions which will affect persons or firms producing, blending, marketing, or using alcohol fuels. These include:

- Continuation from 1984 through 1992 of the exemption from the four cent per gallon federal excise taxes for alcohol-gasoline blends containing at least 10 percent alcohol

- Refunds for excise taxes paid on gasoline blended with at least ten percent alcohol

- New income tax credits for blenders of alcohol-gasoline blends, and for users of straight alcohol fuel

- Continuation through 1985 of the Energy In. vestment Tax Credit for alcohol fuel production equipment

- Authority for simplification of Bureau of Alcohol, Tobacco and Firearms regulation of alcohol fuel producers

- Tax-exempt status for certain industrial development bonds for financing alcohol fuel production facilities

- Federal study on imported alcohol tuel
These provisions of the Act are intended to lessen this Nation's dependence upon imported petroleum by encouraging the construction of domestic alconol fuels production facilities. This summary is a brief guide to alcohol fuel producers, blenders, and marketers - large and small scale - who may qualify for these tax incentives.

For persons considering alcohol fuel production. blending, or marketing, and who believe they may qualify for the tax provisions described, this report should be supplemented by professional tax counsel.

Interested persons may obtain a copy of Public Law 96-223, or the Conference Report, Crude Oil Windfall Profit Tax Act of 1980, U.S. House of Representatives Report No. 96-817 96th Congress, 2nd Session, through their U.S. Senator at the United States Senate, Washington, D.C. 20510, or their U.S. Representative at the House of Representatives, Washington. D. C. 20515. 


\section{Four Cent Per Gallon Excise Taxes Exemption}

- The Exemption

Under the Energy Tax Act of 1978 (Public Law 95618), alcohol-gasoline blends are exempt from the four cent per gallon federal motor fuel excise taxes until October 1, 1984. To qualify for this exemption the biend must contain at least ten percent alcohol of at least 190 proof. Alcohol is defined as ethanol and methanol, but does not include alcohol produced from petroleum, natural gas, or coal. The Windfall Profit Tax Act continues this exemption through December 31, 1992.

It also includes procedures for determining the proof and volume of alcohol that qualifies for the exemption. It provides that the proof of alcohol used to make alcohol-gasoline blends shall be determined prior to the addition of any denaturants (except for those processes that also use the denaturant as a drying agent). With regard to determining the volume of alcohol in the blend, any denaturants (including gasoline) which are added under any formula approved by the Secretary of the Treasury are considered alcohol to the extent that such denaturants do not exceed five percent of the volume of the alcohol (including denaturants).

\section{Refund of Tax on Gasoline Blended With Alcohol}

The Energy Tax Act of 1978 (Public Law 95-618) allows gasoline to be sold free of the four cent per gallon federal excise taxes when blended with at least ten percent alcohol of at least 190 proof. However, that law does not provide for a credit or refund of the tax paid on gasoline if that gasoline is subsequently used to make tax-exempt alcoholgasoline blends by blenders.

The Windfall Profit Tax Act corrects this situation. A person who purchases tax-paid gasoline and uses it to make a tax-exempt alcohol-gasoline blend may now claim a refundable income tax credit equal to the taxes paid on such gasoline. Additionally, if the taxes paid on such gasoline total at least $\$ 200$ during any of the first three quarters of the year, the person may file for a refund on a quarterly basis rather than wait until he files his annual tax return.

This provision applies retroactively to January 1 , 1979. Tax-paid gasoline used to make a tax-exempt alcohol-gasoline blend between January i, 1979, and April 2, 1980 (the date of enactment of the Windfall Profit Tax Act) shall be treated as having been sold or used on April 2. 1980.

\section{Income Tax Credits}

\section{Blended Fuels}

For the period October 1, 1980, through December 31, 1992, a person who blends alcohol fuel with gasoline or any other liquid fuel suitable for use in an internal combustion engine may claim an income tax credit. To qualify the blender must, in the course of his trade or business, sell the blended fuel for use as a fuel, or use it as a fuel himself. For example, a farmer who blends his own alcoholgasoline fuel would qualify for the income tax credit.

The Act specifically states that "casual off-farm production" of alcohol-gasoline blends does not qualify for the tax credit. The Act does not define what constitutes "casual off-farm production," and interpretation of this provision will be the responsibility of the Internal Revenue Service, U.S. Department of the Treasury.

Alcohol is defined as ethanol and methanol, but does not include alcohol produced from petroleum. natural gas, or coal.

The credit is forty cents per gallon of alcohol of at least 190 proof, and thirty cents per gailon of alcohol of at least 150 proof but less than 190 proof. 
The tax credit is reduced by the amount of federal excise taxes exemption applicable to the blended fuel.

The accompanying chart has been prepared to illustrate computation of the income tax credit. For example, alcohol-gasoline blends containing at least ten percent alcohol are exempt from the four cent per gallon motor fuel excise taxes (the federal gas tax). If a person blends $\mathbf{8 5}$ gallons of gasoline (Column $A$ of the chart) with 15 gallons of alcohot (Column B) of at least 190 proof, the resulting 100 gallons of blended fuel (Column C) would be exempt from $\$ 4.00$ in federal excise taxes $(100 \times$ $\$ .04=\$ 4.00$ ).

To compute the income tax credit, multiply the amount of alcohol blended by $\$ .40$ ( 15 gallons $x$ $\$ .40=\$ 6.00$ ) and reduce it by the amount of the excise tax exemption $(\$ 4.00)$. In this example, the blender ends up with a net income tax credit of $\$ 2.00$ on 100 gallons of blended fuel- $\$ 6.00$ (gross tax credit) minus $\$ 4.00$ (excise taxes exemption) equals $\$ 2.00$.

The accompanying chart shows the total lax credit for 100 gallons of alcohol-gasoline blends that contain from one percent to ninely percent atcohol. It is important to note, however, that blends containing less than ten percent alcohol are not exempt from the federal excise taxes of four cents per gallon. In these cases, an income tax credit can be claimed, but the excise taxes must also be paid.

The lax credit is both nonrefundable and taxable. The credit is nonrefundable in that if the tax credit totals more than a taxpayer's tolal income tax liabiiity (the amount of income tax that would otherwise have to be paid), the taxpayer cannot receive a federal tax refund for the difference (the amount the tax credit exceeds the tax liability). The laxpayer can, however, carry forward the excess value of the tax credit to the tax liability in the next tax year. This carry-forward provision applies to the seven tax

$\begin{array}{ccc}\text { Column A } & \text { Column B } & \text { Calumn C } \\ & \begin{array}{c}\text { Alcohol Content } \\ \text { (in gallons) }\end{array} & \begin{array}{c}\text { Tolal Gallons } \\ \text { of Blended }\end{array} \\ \begin{array}{c}\text { Guel } \\ \text { (in gallons) }\end{array} & \text { (190 proof) } & \text { (Add A to B) }\end{array}$

\begin{tabular}{cr}
99 & 1 \\
98 & 2 \\
97 & 3 \\
96 & 4 \\
95 & 5 \\
94 & 6 \\
93 & 7 \\
92 & 8 \\
91 & 9 \\
90 & 10 \\
89 & 11 \\
88 & 12 \\
87 & 13 \\
86 & 14 \\
85 & 15 \\
84 & 16 \\
83 & 17 \\
82 & 16 \\
81 & 19 \\
80 & 20 \\
70 & 30 \\
60 & 40 \\
50 & 50 \\
40 & 60 \\
30 & 70 \\
20 & 80 \\
10 & 90 \\
0 & 100 \\
& \\
\hline 0 &
\end{tabular}

100
100
100
100
100
100
100
100
100
100
100
100
100
100
100
100
100
100
100
100
100
100
100
100
100
100
100
100

- This charl is based on ine Conterence Report, Crude Oil Wudtall Proth Tax Act ol 1980. U S House ol Representalives Report No 96.819.96in Congress. 2nd Session. pages 142-3

- Alcohol-gasoline blends that contain less than len percent alcono are not exempl from the four cent per gation lederal molor fuels excise laxes. Therelore, the gross lax credil is nol reduced in these cases, but the lederal excise laxes of tour cents must ve paid on each gallon ol molor fuet

- If alcohol-gasoline blends or straight alconol luel are sold to cer lain purchasurs exempt from all lederal inotor fuet excise laxes. then ilie gross lax credit is not reduced by the value of the excise taxes exemption Such exenkjt purchasers are tarmers who use the fuel lor on larm use, and units of local government.

\begin{tabular}{|c|c|}
\hline & $\begin{array}{l}\text { Calumn E } \\
\text { Value of }\end{array}$ \\
\hline Cross Tax Credll & Tax Exemption \\
\hline $\begin{array}{c}\text { Gallons of Alcohol } \\
\text { mulliplied by } 40 \\
\text { (40: lime B) }\end{array}$ & $\begin{array}{l}\text { Gatons of Blended } \\
\text { Fuet mulliplied by } 4 c \\
\text { (4i. times C) }\end{array}$ \\
\hline
\end{tabular}

Column $F$ Net Tax Cred 100 gallons Blended Fy (D minus 1

$\$ .40$

.40
80
1.20
1.60
2.00
$\$ 2.40$
2.80
3.20
3.60
4.00
$\$ 4.40$
4.80
5.20
5.60
6.00
$\$ 6.40$
6.80
7.20
7.60
8.00
$\$ 12.00$
16.00
20.00
24.00
$\$ 28.00$
32.00
36.00
40.00

\$o.00"

$0.00^{\circ}$

$0.00^{\circ}$
$0.00^{\circ}$

$0.00^{\circ}$

$\$ 0.00$ "

$0.00^{*}$

$0.00^{\circ}$

$0.00^{\circ}$

$4.00 *$

$\$ 4.00$

$4.00^{\circ}$

4.00

$4.00^{\circ}$

$\$ 4.00$

$4.00^{\circ \circ}$

$4.00^{\circ}$

4.00"

$4.00^{\circ}$

$\$ 4.00^{\circ}$

$4.00^{\circ}$

$4.00^{\circ}$

$4.00^{\circ}$
$\$ 4.00^{\circ}$

$4.00 \%$

$4.00^{\circ *}$

$4.00^{\circ}$
$\$ 40^{\circ}$

$.80^{\circ}$
$1.20^{\circ}$

$1.60^{\circ}$

$2.00^{\circ}$

$\$ 2.40^{\circ}$

$2.80^{\circ}$

$3.20^{\circ}$
$3.60^{\circ}$

$0.00^{\circ}$

5.40 $80^{\circ}$

$1.20^{\circ}$

$1.60^{\circ}$

$2.00 \%$

$\$ 2.40^{\circ}$

$2.80^{\circ}$

$3.20^{\circ}$

$3.60^{\circ}$

$4.00^{\circ}$
$\$ 8.00^{\circ}$

$12.00^{\circ}$

$16.00^{* *}$

$20.00^{\circ}$

$\$ 24.00 \cdot$

$28.00 *$

$32.00^{\circ-}$

$36.00 *$
U.S. National Alcohol Fuels Commission Report:

Alcohol Fuels Tax incentives, A Summery:

Alcohol Fuels Provisions of the Crude Oil Windfall Proflit Tax Act. Aprti, 1980

-. The gross tax credil lor strangnt alcoliol luel sold at retail is re duced by the value of the excise laxes exemplion (as shown in the charl) However, if stranght atcoriol is used as a luel by the pro ducer of the alcurrol neitiel trie exciso laxes nor the exemplion Iroil those laxes spply. Therifore. the gross tax credit is nol reduced in this case for exarrice, a tarmer who produces his own 190 proof alcohot and uses it is a fuel, is eligible for the lull tax credit of 40 : per gallon of $190 \mathrm{prool}$ alcohol. 
years after the year during which the credit was originally earned. However, no credit may be carried forward to tax years beginning after December 31, 1994.

The credit is taxable in that the amount of tax credit claimed must be added to the blender's gross income on which tax liability is based. In essence, the tax credit is added to his income, then tax owed calculated on that income, and then the tax credit subtracted from the tax owed.

For determining the proof, volume of alcohol, and the amount of denaturants used in alcohol (either blended or straight) qualifying for income tax credits.the same procedures are used as in the case of alcohol used in blends qualifying for the excise taxes exemption. These procedures are explained earlier on page 4 of this report under "Four Cent Per Gallon Excise Taxes Exemption."

\section{Straight Alcohol Fuel}

For the period October 1, 1980, through December 31,1992 , a person (1) who uses straight alcohol fuel (one hundred percent alcohal) as a fuel in his trade or business, or (2) who sells straight alcohol fuel "at retail to a person and placed in the tank of such person's vehicle, may claim an income tax credit. In situations where the retail seller is eligible for the credit, no credit is allowable for the user. Alcohol includes ethanol and methanol, but does not include alcohol of less than 150 proof, or alcohol which is produced from petroleum, natural gas, or coal.

The tax credit is forty cents per gallon of alcohol of at least 190 proof, and thirty cents per gallon of alcohol of at least 150 proof but less than 190 proof. As in the case of the income tax credit for alcohol blended with other motor fuels, the tax credit for straight alcohol fuel is taxable and nonrefundable, and the same seven-year carry-forward provision applies. The tax credit is reduced by the amount of federal excise taxes exemption applicable (such as in the case of retail sale). 


\section{Energy Investment Tax Credit for Biomass}

\section{The Credit}

Under the Energy Tax Act of 1978 (Public Law 95-618), the ten percent Energy Investment Tax Credit is available through 1982 for boilers, burners, and related pollution control and fuel handling equipment that use primarily fuels (such as biomass) other than petroleum or natural gas. Also eligible is equipment that converts altemate substances like biomass into a synthetic solid, liquid, or gaseous fuel. However, the Energy Investment Tax Credit does not apply to land involved with alcohol fuel production.

The Windfall Profit Tax Act retains through 1982 the ten percent Energy Investment Tax Credit for "alternative energy property," and creates for the period January 1, 1983, through December 31, 1985, a new eligibility section for "biomass property." Both of these sections apply to equipment that converts biomass into alcohol fuel. The Congress intended that equipment that converts biomass into alcohol fuel be eligible for the ten percent Energy investment Tax Credit from January 1, 1983, through December 31,1985 , but only if the equipment producing the alcohol uses a primary energy source (i.e.. more than fifty percent of the full energy requirement) other than oil, natural gas, or a product of oil or natural gas. The effective date of this limitation on the primary energy source was explained by Senator Russell Long, Chairman of the Senate Finance Committee, during the Senate's Windfall Profit Tax Act debate (see March 27, 1980 Congressional Record, page S 3135).

Biomass is generally any organic substance other than oil, or natural gas. Biomass includes waste, sewage, sludge, grain, wood, oceanic and terrestrial crops, and crop residues.
Beginning January 1, 1983, coal may not be used as a feedstock if the ten percent Energy Investment Tax Credit is claimed.

Boilers or burners which use biomass, and biomass fuel or feedstock handling, storage, and preparation equipment and pollution control equipment are also eligible for the extended ten percent Energy Investment Tax Credit.

For the period from January 1, 1980, through December 31, 1985, equipment that stores fuel derived from garbage at the site where the fuel is - produced is eligible for the ten percent Energy Investment Tax Credit. This is a new provision not included in earlier federal law.

It should be noted that the permanent business investment tax credit of ten percent continues to apply in addition to the ten percent Energy Investment Tax Credit. This means a total investment tax credit of twenty percent may be claimed for eligible investments.

\section{Reduction of the Energy Investment Tax Credit}

The Windfall Profit Tax Act provides that to the extent property (excluding land) is financed by taxexempt industrial development bonds or certain other government subsidized energy financing. the Energy Investment Tax Credit is not available. For example, a property, fifty percent of which is financed by tax-exempt bonds; would qualify for - Only fifty percent of the Energy Investment Tax Credit.

This does not, however, apply to loan guarantees.

In general, this provision will be effective January 1 , 1983. However, in the case of the Energy Investment Tax Credit for equipment that stores fuel derived from garbage, it becomes effective January $1,1980$. 


\section{Alcohol Fuel Plant Operating Permits}

\section{Regulatory Simplification}

The Windfall Profit Tax Act creates a new section in the Internal Revenue Code which classifies separately distilled spirits for use as a fuel, and distilled spirits for use as a beverage.

In issuing regulations under this new section, the Secretary of the Treasury is directed to take steps to expedite the processing of applications, establish a minimum bond, and generally encourage and promote the production of alcohol for fuel purposes.

Under the broad authority given the Secretary by this section, it is expected that the regulation of alcohol fuel production will be simplified. This is likely to include shortened application procedures and forms, reduced recordkeeping and reporting requirements, and lower bonding requirements.

This new section becomes effective July 1, 1980 . However, the Bureau of Alcohol, Tobacco and Firearms, acting for the Secretary of the Treasury, must issue regulations before this new legal authority can be implemented. Under these new regulations, it is expected that three new categories of operating permits will be established: small, medium, and large. The current categories of experimental and commercial operating permits may also be continued. However, the Act only requires the establishment of a small plant category. For information on operating permits contact: Bureau of Alcohol, Tobacco and Firearms, U.S. Department of the Treasury, Washington, D.C. 20226, telephone (202) $566-7531$.

\section{- Small Plants}

The Windfall Profit Tax Act defines a small plant as having a maximum annual production capacity of 10,000 proof gallons of alcohol. The law requires the Bureau of Alcohol, Tobacco and Firearms to approve or reject a properly completed small plant operating permit application within sixty days, or else the application is legally deemed approved. No bonding requirements are to be established for a small plant. 


\section{Tax-Exempt Bonds for Alcohol Fuel from Solid Waste}

Prior to enactment of the Windfall Profit Tax Act, federal law permitted the financing of solid waste disposal facilities through tax-exempt industrial development bonds. The Windfall Profit Tax Act expands the definition of solid waste disposal facilities to include property which is used primarily to process solid waste into alcohol.

For a facility to be a "qualified alcohol-producing facility" under this provision it must satisfy three requirements:

- The primary product obtained from the facility must be alcohol (the Act does not require the alcohol to be of any minimum proof)

- More than half of the feedstock used in the production of alcohol must be solid waste or a feedstock derived from solid waste

- Substantially all of the solid-waste-derived feedstock must be produced at a facility located at or adjacent to the site of the alcohol-producing facility, and both facilities must be owned and operated by the same person. (A person "owns" such facilities if the facilities are owned for tax purposes by that person.)

A facility need not satisfy the last of these requirements if two conditions are satisfied:

- Substantially all of the solid-waste-derived feedstock used must be from a facility that went into production during 1977, is located within the limits of a city, and is in the same metropolitan area as the alcohol-producing facility
- Prior to March 1, 1980, negotiations were under way between a government authority and an educational, scientific, or similar nonprofit organization regarding the use of a special alcohol production process

These conditions can be satisfied only if the total obligations issued for a project do not exceed $\$ 30$ million, and if the obligations are issued prior to January 1, 1986.

The new provisions governing tax-exempt industrial development bonds for financing solid waste disposal facilities that produce alcohol apply to obligations issued after October 18, 1979. The Windfall Profit Tax Act also provides that such bonds will not be tax exempt if the bonds are guaranteed by the federal government, or if any payment of the principal or interest is made with funds from a federal, state, or local energy program.

The Windfall Profit Tax Act also expands the definition of a solid waste disposal facility that can be financed through tax exempt industrial development bonds to include solid waste disposal facilities that produce steam or electricity. The requirements for such steam or electric facilities are similar to, but not in all cases the same as, the requirements for a qualified alcohol-producing facility. 


\section{State Financing of Renewable Energy Property}

The Windfall Profit Tax Act defines "renewable energy property" as property used to produce energy. (including heat, electricity, and substitute fuels) from renewable energy sources (including wind. solar, and geothermal energy, waste heat, biomass. and water).

The Act provides that industrial development bonds used to finance renewable energy property will be lax exempt if four conditions are met:

- The bonds must be general obligations of a state

- Taxes must be levied in sufficient amount to provide for the payment of principal and interest on the bonds

- The amount of all obligations (whether or not industrial development bonds) under the state program for renewable energy property may not exceed $\$ 500$ million or one-half of one percent of the value of all property within the state, whichever is smaller

- The state constitution permits state financing of small-scale energy projects. (A constitutional amendment to permit such financing must have been approved by the legislature before October 18, 1979).

These provisions of the Windfall Profit Tax Act apply to obligations issued after the date of enactment of the Act, April 2, 1980.

The Windfall Profit Tax Act also provides that such bonds will not be tax exempt if the bonds are guaranteed by the federal government, or if any payment of the principal or interest is made with funds from a federal, state, or local energy program (other than the state-issued bonds in question).
When the Windfall Profit Tax Act was enacted on April 2, 1980, the only state known to qualify under this provision of the Act was the State of Oregon.

\section{Study of Imported Alcohol}

The Windfall Profit Tax Act requires the Secretary of the Treasury to send Congress by October 2. 1980. a report on imported alcohol fuels. The report is to include the Secretary's recommendations on what methods may be used to limit alcohol fuels imports, including, but not limited to:

- Denial of federal motor fuels excise taxes exemption and income tax credits to fuels produced from imported alcohol

- Import quotas and duties on alcohol fuel

- Strict surveillance of alcohol fuels imports to monitor their effect on the domestic alcohol fuel industry

This report is to be provided to the Senate Committee on Finance and the House of Representatives Committee on Ways and Means, which have jurisdiction over foreign trade matters. 


\section{Annual Reports on Alcohol Fuels}

On April 1 of each year, beginning in 1981, and ending in 1992, the Windfall Profit Tax Act requires the Secretary of Energy to submit to Congress a report on the use of alcohol fuels. The report is to include:

- A description of the firms engaged in the alcohol fuel industry

- The amount of alcohol fuels sold in each state, and the amount of gasoline saved in each state by reason of the use of a!cohol fuels

- The revenue loss resulting from the federal motor fuels excise taxes exemption and the income tax credits for blended and straight alcohol fuels, and the loss of revenue to the Highway Trust Fund resulting from the excise taxes exemption

- The cost of production and the retail cost of alcohol fuels as compared to gasoline and special fuels not mixed with alcohol

The Secretary of Energy is to prepare each annual report in consultation with the Secretary of the Treasury and the Secretary of Transportation. 


\title{
Entitlements for Alcohol/DoE
}

\author{
Description of Program \\ (Subsidy for Alcohol producers)
}

The Economic Regulatory Administration (ERA) of the Department of Energy (DOE) administers the Crude Oil Entitlements Program which is intended to equalize the average cost of crude oil among all refiners. It is accomplished through a system of monthly cash transfers whereby fikns which have access to low cost, domestic price controlled oil make paynents to firms which. purchase expensive imported or danestic uncontrolled or upper tier priced oil. Because the price regulations and the entitlements program have the combined effect of holding average crude oil prices in the United States below world market prices, petroleum substitutes have been less competitive in relation to crude oil than would be the case if crude oil were not controlled. Also, because the entitlements progran essentially subsidizes imported oil, ERA has determined that alcohol Euel, which displaces foreign oil, should receive the same subsidy as foreign oil.

In an effort to remove the regulatory disincentive to the production and use of petroleun substitutes caused by the crude oil price regulations, ERA anended its regulations in May of 1978, to provide entitlements benefits, on a case by case basis, for certain petroleum substitutes, including non-petroleum based ethanol used as blend stock for gasohol. (43 FR 21429, May 18 1978; effective date July 1 , 1978.) Archer-Daniels-Midland Corporation was the first firm to apply for and be awarded entitlements treatment for its ethanol production. (ERA Decision and Order, Docket fERA-APS-78-2; August 23, 1979.)

On October 31, 1979, ERA anended the entitlements progran further to extend the benefits avallable to alcohol producers automatically, rather than unon application. (44 FR 63515, Novenber 5, 1979.) A second finm, Midwest Solvents, began receiving entitlements for ethanol and more finss are expected to begin receiving these payments in the coning months. The benefits are available for ethanol derived from domestic biomass which is mixed with gasoline for use as fuel in the United States. The entitlements earned by eligible finms are equivalent, on a b.t.u. basis, to the entitlements earned on uncontrolled crude oil, 1.e., approximately five cents per gallon of alcohol at current entitlement levels.

\section{Responsible officials for Further Information}

Peter Antonelli (202) 254-7434, David Welsh (202) 254-3336 2000 M St. phone no., etc. 


\section{Description of the Program}

\section{Authorizing Legislation}

Section 222(a) of Title II of the Commity Services Administration Act which establishes the Fnerging Energy Conservation Services and provides auttiority for this progran. The progran will address the energy needs of low incame people with the goals of lessening the impact of the high energy costs on the poor and reducing both individual and family energy consunption.

- Types of Funding

Direct grants to public and private non-profit organizations and agencies for research, development and demonstration of energy sources. Alcohol fuels qualify as an "energy source".

- Funding Limits

$\$ 3.7$ million has been appropriated for the implementation of this program in $E Y 1980$.

- Eligibility Criteria

CA's, non-profit CDC's, SEOO's and other public or private non-profit organizations and agencies that meet CSA eligibility criteria may apply. Grant awards must be directed to addressing the needs of the poor and near poor.

\section{- Application Procedure}

Applications should be submitted to the Commity Services Administration, office of Program Development, 1200 19th Street, N.W. Wasinington, D.C. 20506.

- Status

The FY 1980 allocation to CSA's energy prograns has been obligated and no other funds are available at this time.

CSA has awarded a $\$ 150,000$ grant to the National Center for Appropriate Technology (P.0. Box 3868, Butte, Montana) to design five prototype, portable, small-scale fuel alcohol stills, suited to on-fam use by low-incone fanmers. Should funds become available, CSA will award up to five small grants to five nural energy grantees to field-test the stills and train local low-income people in construction, operation and maintenance of the stills. Once proven at these sites, it is expected that the stills will be pranoted for on-fam use by low-income famers through Farmers lome Adninistration or other financing sources.

- Responsible Officials for Funther Information

Richard M. Saul, Energy Programs, Roan 334

Comunity Services Adninistration

1200 19th Street, N.W., Washington, D.C. 20506

(202) 632-6503 
Bureau of Alicohol, Tobacco \& Eireanms

Department of the Treasury

Description of the Program

The Bureau of Alcohol, Tobacco and Fireams (ATF) is responsible for adninistering the laws in the Internal Revenue Code that relate to distilled spirits (alcohol). ATF impacts upon the production and sale of alcohol fuel in one of four different ways: permit approval or licensing, bonding, denaturing, and regulations on incorted alcohol.

- Permit Agoroval

Section 5171 (c) (1) of the Internal Revenue Code (Code) provides that every person must make an application to register with ATF before cormencing the operation of a distilled spirits plant. Section 5171 (d)(1) of the code requires each person to apply for and obtain a pemit fran ATF In order to engage in the operation of a distilled spirits plant. Section 5002 (a) (8) defines "distilled spirits" as ethyl alcohol, ethanol, or spirits of wine that include all dilutions and mixtures fron whatever source or by whatever process produced.

The law provides for two types of distilled spirits plant (DSP) pemits:

1. gperating or camercial pemit. This permit authorizes alcohol to be produced for sale or any nonexperimental purpose. Qualifying for an operating pernit is an extensive procedure that requires preparation of numerous forms and involves investigations by ATF to determine whether operation of the DSP can be legally approved.

2. Experimental DSP permit. This pemit authorizes the experimentation and development of the distillation and industrial uses of alcohol, and does not authorize the sale of alcohol. Because an experimental DSP penrit authorizes the production of alcohol for personal fuel use and not for sale, qualifying for this permit is a more abbreviated process. There are no prescribed apolication forms. A taxpayer need only write a letter containing his name, address, and telephone number to the Regional Regulatory Adninistrator for the region where the alcohol plant is to be located (see Appendix I for a camplete list of addresses and phone numbers of all ATF regional offices). In addition, each letter must completely describe all land, buildings, and equipment (including stills, vats, and tanks) to be used in producing alcohol; the planned uses of the alcohol (for example, as heating fuel, lawriower, tractor, or other engine fuel); the property on which vehicles using the alcohol as fuel will be operated; the process used to produce alcohol including feedstocks, yeasts, enzymes, and distilliation method; how the solid and liquid waste from the alcohol plant will be disposed of for environmental impact purposes; and the type of security used to protect the alcohol produced from theft or other unauthorized renoval from the plant premises. The letter should also include an estimate of the anount of alcohol an applicant intends to produce during a 15 day period. 
Since January 1, 1979, ATF has received more than 6,000 inquiries concerning alcohol fuel production. Fanmers, small businessmen, private citizens, corporations, and others interested in developing alternative fuels have maintained that fuel aloohol is an important contribution to the United States' energy resources.

Qurrent law, however, does not include the necessary provisions to accomodate these interests. (See Subtitle E, Chapters 51-53 of the code.) The law is too cumbersome for this new alcohol fuel industry and many potential alcohol producers find that the overall ATF requirements for alcohol production are prohibitively expensive and time-consuming.

Proposed legislation contained in $\$ 236$ (e) of R.R. 3919, the Crude Oil Windfall Profit Tax Act of 1979 (Act), would sirplify statutory and regulatory requirements. Initiated by the Department of the Treasury and ATF, this legislation was introduced in the Senate on May 22, 1979, by Senator Birch Bayh (D-Ind.), Chaiman of the National Alcohol Fuels Camission (NAFC) as S.1200, and in the House of Representatives on May 23, 1979, by Ways and Means Chaiman Al Ulliman (D-Wash.) as B.R. 4215 .

As proposed, the legislation would simplify the permit application process by which an individual can establish a distilled spirits plant intended to produce alcohol for use as fuel. For example, $\$ 236$ (e)(1) of the Act would create a new $\$ 5161$ of the Code (relating to distilled spirits for fuel use). Subsections (a) (1) and (3) empower the Secretary of the Treasury (Secretary) to expedite all apolications to establish a distilled spirits plant for the purpose of producing, orocessing, storing. using, and distributing distilled spirits to be used exclusively for fuel use and generally to encourage and pranote the production of alcohol for Euel purposes. Subsection (b) gives the Secretary authority even to waive the penit application requirement if it is necessary to cann out the provisions of new 55161. As noted above, under subsection (C) (1) (A), an application for an operating pemit for an eligible distilled spirits plant (cefined in subsection (c)(4) as a plant that is used to produce distilled spirits exclusively for fuel use where production does not exceed 10,000 proof gallons per year) shall be simplified to the greatest extent possible so as to expedite the issuance of such permits.

- Bona Requirenents

Individuals entering the business of distilling alcohol are required to file a bond to cover the liability for the excise taxes on the alcohol produced. This bond and the security requirements are designed to:

- prevent the loss of any tax revenue, and

- assure the alcohol produced is not diverted to illegal purposes. 
ATF ascertains the bond by detemining the volume of alcohol produced at a specific proof level over a specific period of time. The present rate is $\$ 10.50$ per ( 100 proof) gallon produced over a period of 15 days. In general, the formila used to determine the bond is designed to minimize the financial burden on the producer and also to minimize the risk the covernment takes regarding potential loss of tax revenue. The producer, in actuality, pays an annual preniun which is less than the actual tax liability by searing a surety bond for the tax liability with an approved Treasury bonding campany.

Snall Producer: There is no bond requirement for this producer. It is believed the risk to the revenue by this producer is limited because of the volume of alcohol production (10,000 100 proof gallons) and the probability of detection if significant quantities of production are diverted to illegal purposes.

Medium Producer: ATF will detenmine the bond based on the potential tax liability incurred by the producer during 15 days production of distilled spirits. For example, if the producer produces 100,000 (100 proof) gallons annually (the maximum allowable under this category) his tax liability will be $\$ 60,576$. The approximate cost of a surety bond to the producer is $\$ 730$ annually.

Large Producer: ATs will detemine the bond requirement for this producer based on the potential tax liability incurred by the producer during a 15 day period. For exarple, if he produces 200,000 proof gallons annually, his potential tax liability is $\$ 121,154$. However, the maximm sum of the bond would be $\$ 1,200$. (Note: the above may be changed prior to passage of H.R. 3919).

Records and Reporting

ATF will require each producer to maintain records of his production process and the disposition of the alcohol. At regular intervals, the producer will provide information to ATF for verification and auditing. ATF will not require the producer to maintain a separate set of records If he maintains commercial records that contain the needed information. Camercial records maintained for accounting and tax purposes will suffice.

Small producer: This producer would be expected to maintain records of:

- the quantity and proof of alcohol produced,

- the quantities and types of materials added to the alcohol to destroy the beverage character of the alcohol, and

- the disposition of the denatured alcohol. 
Once a year the small producer will file a report with ATF stating the volume and proof of alcohol produced annually and the disposition of the ienatured alcohol.

Medium Producer: This producer will maintain records of:

- the volume and proof of alcohol produced,

- the quantities and types of materials used to destroy the alcohol's beverage character, and

- the disposition of the denatured alcohol.

Twice a year, the producer will file a report with ATF delineating the volume and proof of alcohol produced monthly, and its disposition.

Large Exoducer: This producer will maintain records of: -

- the materials received and used to produce alcohol,

- the volume and proof of alcohol produced,

- the quantities and types of material added to the alcohol to alter its beverage character, and

- the disposition of the denatured alcohol.

Four times a year, the producer will file a report with AIF delineating the volume and proof of alcohol proauced monthly and its disposition.

\section{Destruction of the Alcohol's Beverage Craracter (Denaturing)}

AIF will require all producers of alcohol for use as a fuel to add substances to the alcohol destroying its beverage character - make it unfit for human consumption. This technique is called denaturing the alcohol. All alcohol produced by the producers must be denatured before it leaves the premises on which the production facilities are located.

There are many substances such as gasoline, kerosene, or other chenicals, which can destroy the beverage character of the alcohol. In adiition, there are several different formulas for the destruction of the beverage character of alcohol. AIF, however, is willing to work with a producer to develog an acceptable formula which will meet his specific needs.

For example, two ATF published formulas for denaturing alcohol for sale are Formula NO. 18 and Formula NO. 19, both of which involve expensive chemicals e.g. methyl isobutyl ketone. (27 CFR Part 212, Subpart C). However ATF has a proposed less expensive formula $(\cos A-20)$ which provides for the adaition of five gallons of gasoline to each 100 gallons of alcohol, which is currently permitted on a case-by-case basis. 


\title{
II TIH: SMIATS. \\ STIATI: BIJJ, IN. 1245 \\ BY WATKIIIS
}

1

\begin{abstract}
AN ACT
REIATING TO P.EEUNS TO DISTRIBUTORS OF CASOIIOL; AIFNIING SECTION $6,3-2432$,

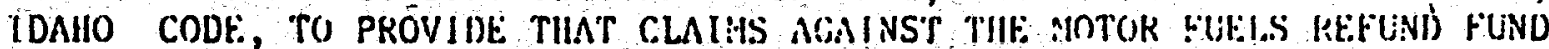
SHALI. BE: PAIO IN TIIE ANOUNT OF FIFTY PRP CLNT OF THE CLAIN AS ALIOWLD,

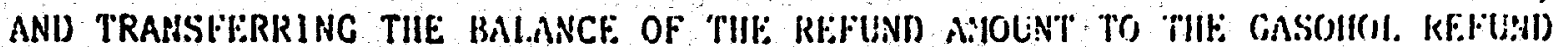

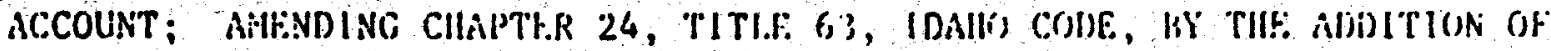

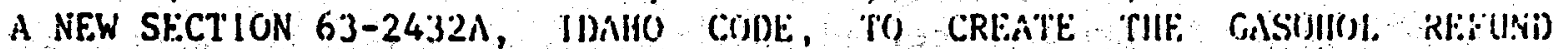
ACCOUNT AND PROVIDE EOR PAYIIENTS OF REFUNUS FROH TIIE ACCOUIVI.
\end{abstract}

Be It Enacted by the Legislature of the stote of luaho:

SECTION 1. That Section 63-24.32, Jdaho Colle, be, and the same is hereby amended to rend as follows:

63-2432. DISTRIBUTION OF TAX REVENUES. (1) The revenues received from. the taxes inposed by sections 63-2403 and 63-2406, Idahn Corle, and any penalties, interest, or deficiency additions, shall be paid over to the state treasurer by the commission, to be distributed as follows:

(a) An amount of inoney equal to the actual cost of collecting, administering and enforcing the motor fuel tax act by the commission, as determined by the conuission and certified ruarterly to the state auditor, shall be transferred back to the commission; provided, that the amount so transferred back to the comission shall not exceed the amount authorized to be expended by regular appropriation authorization.

(b) 1. An amount of money shall be transferred to the motor fuels refund fund, which is hereby created, sufficient to pay current refund claims; provided that during the period July 1, 1980, Lo June 30,1984 , each claim shall be treated as follows: (i) each claim stiall be paid in the amount of fifty per cent $(50 \%)$ of the claim as filed and allowed; and (ii) an amount equal to fifty per cent of the claims paid shall be transferred, no less frequently than quarterly, to the gasohol refund account, created in section 63-2432A, Idaho Code. AlI tefunds authorized to be paid by this act shall be paid from the motor fuels refund fund.

2. At the end of each fiscal year, if claims against the gasohol refund account exceed the revenue in the account, an amount of money shall be transferred to the gasohol refund account sufficient to pay outstanding claims against the account.

(c) At the beginning of each fiscal year, the sum of one hundred thousand dollars $(\$ 100,000)$ shall be transferred to the railroad grade crossing protection account in the dedicated fund, to pay the amounts from the account pursuant to the provisions of section $62-304 \mathrm{C}$, Idaho Code.

(d) From the balance remaining with the state treasurer after 
transferring the amounts in subsection (a), (b) and (c) of this section:

(1) one per cent ( $1 \%$ ) shall be Lransferred to the waterways improvement fund, as created in chapter 15, tille 57, ldaho cole; (2) one per cent ( $1 \%$ ) stiall be transferred to the off-road motor vehicle fund;

(3) sixteen and two-thirils per cent $(16.67 \%)$ shall be divided among incorporated and sperially chartered rities, in the same proportion as the population of said incorporated or specially chartered city bears to the total population of all such incorporated or specially chartered cilies as siown by the last regular or special federal census; and

(4) eighty-one and one-third per cent $(81.33 \%)$ shall be transferred to the state highway fund, as created in section 40-2210, Idaho Code.

(2) The revenues received from the taxes imposed by section 63-2409, Idaho Code, and any penalties, interest, or deficiency additions, shall be paid over to the state treasurer by the commission to be deposited in the state acronatics fund, as provided in section $21-211$, [daho Cone.

(3) The distribution and transfers reyuired by subsections (1) and (2) of this section shall be made as frequently as required, and the state auditor and state treasurer shall take all necessary actions to achieve such transfers and distributions.

SECTION 2. That Chapter 24, Title 63, Idaho Code, be, and the same is hereby anended by the addition thereto of a NEW SECTION, to be known and designated as Section 63-2432A, Idaho Code, and to read as follows:

63-2432A. GASOHOL REFUND ACCOUNT. There is hereby created the gasohol refund account in the dedicated fund, to which shall be credited an amount of money transferred from the refund fund, created in section 63-2432, Idaho Code, equal to fifty percent $(50 \%)$ of all refunds filed against the refund fund.

(a) Any licensed distributor of motor fuel may file claims against the gasohol refund account in the amount of four cents (\$.04) per gallon of gasohol on which motor fuels tax has been paid, using forms and procedures prescribed by the state tax commission. Gasohol is defined for the purposes of this section as a motor fuel containing a minimum of ten per cent ( $10 \%$ ) blend of anhydrous ethanol manufactured in the state of Idaho from agricultural or forest products grown in the state of Idaho or wastes of such products.

(b) On June 30 , annually for the duration of this provision, any funds remaining in the account and not allocated to the payment of claims pursuant to subsection (a) of this section shall be distributed, in the full anount of the moneys remaining, in an amount proportionate to the original claim, to each claimant under the provisions of section 63-2432(b), Idaho Code. 
On page 1 of the printed bill, in line 26 , following "1984," insert: "subject to annual review by the legislature,".

On page 1 of the printed bill, in line 35 , following the word "account" insert "from the motor fuels refund fund".

On page 1 of the printed bill, in line 36 , following the word "account" insert "limited to the moneys which remain in the motor fuels refund fund".

ARENDMENT TO SECTION 2

On page 2 of the printed bill, delete 1 ines 38 and 39 , and insert in 


\section{TIIE SFINATF \\ SFNATE BIIS, INO. 1247 \\ BY PATKIIS}

AN ACT

AMENDING CHAPTER 1, TITLE 63, IDAHO CODE, BY THE ADDITION OF A NEW SECTION TO BE KNOWN AND DESIGNATED AS SECTION 63-105CC, IDAII COIIE, PROVIDING FOR CERTAIN PROPERTY USED FOR THE PURPOSE OF MANUFACTURING GRAIN ALCOHOL FOR USE AS GASOHOL TO BE EXEMPT FROM PROPERTY TAXES AND PROVIDING A SCHEDULE FOR SUCH EXEMPTIONS; AND AMENDING SECTION 63-2402, IDAHO CODE, PROVIDING FOR THE ADDITION OF A DEFINITION OF GASOHOL.

Be It Enacted by the Legislature of the State of Idaho:

SECTION 1. That Chapter 1, Title 63, Idaho Code, be, and the same is hereby amended by the addition thereto of a NEW SECTION, to be known and designated as Section 63-105CC, Idaho Code, and to read as follows:

63-105CC. PROPERTY EXEMPT FROM TAXATION -- PROPERTY FOR THE PUIROSE OF MANUFACTURING GRAIN ALCOHOL FOR USE IN GASOHOL. (1) Any personal property or improvements used or constructed for the purpose of manufacturing grain alcohol for use as a blend for motor fuels comminly referred to as "gasohol," as defined in section 63-2402, Idaho Code, is exempt from property taxes according to the following schedule:

(a) During the first year of use, one hundred per cent (100\%) of the market value for assessment purposes of such property shall be exempt; (b) During the second year of use, seventy-five per cent ( $75 \%$ ) of the market value for assessment purposes of such property shall be exempt; (c) During the third year of use, fifty per cent (50\%) of the market value for assessment purposes of such property shall be exempt;

(d) During the fourth year of use, twenty-five per cent (25\%) of the market value for assessment purposes of such property shall be exempt; (e) During the fifth and succeeding years of use, none of the market value for assessment purposes of such property shall be exempt.

(2) The exemption granted under this section shall not be extended to the land upon which the property or improvements are located.

(3) Application for this exemption shall be filed with the county assessor not later than March 1 of the year for which the exemption is requested, on forms provided by the state tax commission. The application shall describe and locate the specific property or improvements to be exempted.

SECTION 2. That Section 63-2402, Idaho Code, be, and the same is hereby amended to read as follows:

63-2402. DEFINITIONS. As used in this act, the following definitions shall apply:

(a) "Motor vehicle" means every self-propelled vehicle designed for operation or required to be licensed for operation upon a public highway. 
(b) "Motor fuel" means any substance, the chief use of which is as fuel for the propulsion of motor vehicles or motor boats. Motor fuel also means aircraft engine fuel when such aircraft engine fuel is used for propulsion of motor vehicles or motor boats. Motor fuel does not include fuels as defined in subsection (e) of section 49-1230, Idaho Code.

(c) "Gasohol" means a motor fuel, special fuel, or aircraft engine fuel containing a mixture of at least ten percent ( $10 \%$ blend anhydrous ethanol manufactured in the state of Idaho from agricultural or forest products grown in the state of Idaho or wastes of such products.

(d) "Aircraft engine fuel" means any substance, the chief use of which is as fuel for the propulsion of aircraft.

(de) "Person" means any individual, firm, copartnership, association, corporation (both private and municipal) or other group or combination acting as a unit, and the plural as well as the singular number, unless the intent to give a more limited meaning is disclosed by the context.

(ef) "Licensed distributor" shall mean any person who receives motor fuel and/or aircraft engine fuel in this state, provided he has qualified with the state tax commission of the state of Idaho.

( $f g$ ) "Public highway" means every way or place, including a toll road, generally open to the use of the public as a matter of right, for the purpose of vehicular travel, notwithstanding that the same may be temporarily closed for construction, reconstruction, repair or maintenance.

(gh) "Retail dealer" means any person engaged in the retail sale of motor fuel and/or aircraft engine fuel to the public or for use in this state. Idaho.

(hi) "Commission" means the state tax commission of the state of 


\section{AMENDMENTS TO SECTION 1}

On page 1 of the printed bill, in line 9, following "Chapter", delete
" 1 " and insert: " $30 "$ ".
On page 1 of the printed bill, in line 11, following "Section", delete "63-105CC" and insert: "63-3025".

On page 1 of the printed bill, in line 12, delete $" 63-105 \mathrm{CC}$. PROPERTY EXIEMPT FROM TAXATION --", and insert: "63-3025. CREDIT FOR VALUE OF".

On page 1 of the printed bill, in line 13, following the word "MANUFACTURING" delete the word "GRAIN" and insert in lieu thereof: "ETHANOL".

On page 1 of the printed bill, in line 14, following the word "manufacturing" delete the word "grain" and insert in lieu thereof: "ethanol".

On page 1 of the printed bill, in line 16, following "Code," delete the remainder of the line and "erty" in line 17, and insert: "shall be allowed as a credit against individual or corporate income".

On page 1 of the printed bill, in line 18, following "use," delete the remainder of the line and all of line 19, and insert in lieu thereof: "eight-tenths of one per cent $(0.8 \%)$ of the value of such property shall be allowed as credit, but not exceeding eight-tenths of one per cent $(0.8 \%)$ of the gross value of ethanol produced in that year;".

On page 1 of the printed bill, in line 20, following "use," delete the remainder of the line and all of line 21, and insert in lieu thereof: "six-tenths of one per cent $(0.6 \%)$ of the value of such property shall be allowed as credit, but not exceeding six-tenths of one per cent $(0.6 \%)$ of the gross value of ethanol produced in that year;".

On page 1 of the printed bill, in line 22, following "use," delete the remainder of the line and all of line 23, and insert in lieu thereof: "four-tenths of one per cent $(0.4 \%)$ of the value of such property shall be allowed as credit, but not exceeding four-tenths of one per cent $(0.4 \%)$ of the gross value of ethanol produced in that year;".

On page 1 of the printed bill, in line 24, following "use," delete the remainder of the line and all of line 25, and insert in lieu thereof: "two-tenths of one per cent $(0.2 \%)$ of the value of such property shall be allowed as credit, but not exceeding two-tenths of one per cent $(0.2 \%)$ of the gross value of ethanol produced in that year;".

On page 1 of the printed bill, in line 26, following "of the" delete the remainder of the line and all of line 27, and insert in lieu thereof: "value of such property shall be allowed as a credit.".

On page 1 of the printed bill, in line 28, following "The" delete "exemption" and insert: "credit".

On page 1 of the printed bill, in line 30 , following "(3)!, delete the remainder of the line and all of lines 31 through 34 , and insert in lieu thereof: "In no case shall credit allowed under this section exceed the income tax liability of the claimant.". 
$9 \begin{array}{r}8 \\ 9\end{array}$ 10

AMENDMENTS TO SECTION 2

On page 2 of the printed bill, in line 4, following the word "boats" insert:" ", including motor fuel containing a mixture of at least ten percent ( $10 \%$ ) blend anhydrous ethanol commonly known as gasohol".

On page 2 of the printed bill, in line 6 , following the words "motor fuel" delete ", special fuel, or aircraft engine"; and at the beginning of line 7 , delete the word "fuel".

\section{CORRECTIONS TO TITLE}

On page 1 of the printed bill, in line 2, following "CHAPTER", delete " 1 " and insert: "30".

On page 1 of the printed bill, in line 3 , following "SECTION" delete "63-105CC" and insert "63-3025".

Or page 1 of the printed bill, in line 4, following the word . "MANUFACTURING" delete the word "GRAIN" and insert in lieu thereof: "ETHANOL".

On page 1 of the printed bill, in line 5 , following "To BE" delete "EXEMPT FROM PROPERTY" and insert: "AILOWED AS A CREDIT AGAINST INCOME".

On page 1 of the printed bill, in line 6 , following "such" delete "EXEMPTIONS" and insert: "CREDITS". 
APPENDIX B

FEEDING REGULATIONS

FOR COLORADO AND

OREGON 


$$
\therefore--1=0
$$

AFR I 1900

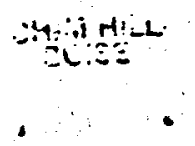

COLORADO DEPARTMENT OF AGRICULITURE

DIVISION OF INSPECTION AND CONSUNER SERVICES

FEED SECIION

\author{
RULES AND REGULATIONS \\ REGARDING \\ PROCESSED ANIMAL WASTE RRODDCTS
}


RULES AND REGULATIONS

REGARDING PROCESSED ANIMAL WASTE PRODUCTS

\section{TABIE OF CONIENTS}

Page

I. IEGAI AUTHORITI............................. I

II. DEFINITIONS.............................. 1

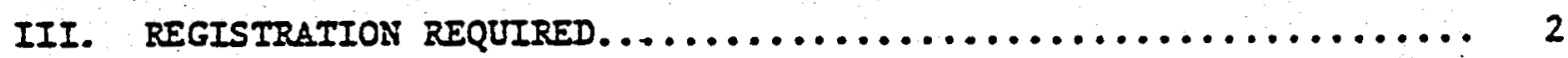

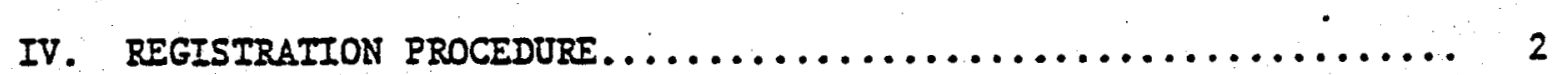

v. REGISIRATION REFUSED........................ 2

vI. QUALITI STANDARDS.......................... 3

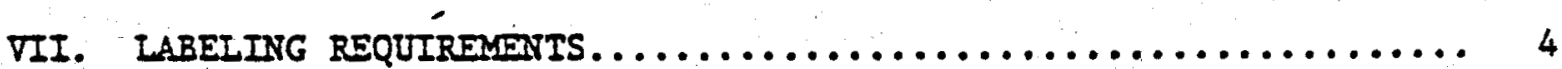

VIII. TESTING REQUIRED.......................... 5

IX. RECORDS REQUIRED........................... 5

X. REGISTRATION REVOCATION, SUSPEVISION, ANNULMENT,
LIMITIAIION OR MODIFICAIION $\ldots \ldots \ldots \ldots \ldots \ldots \ldots \ldots \ldots \ldots \ldots \ldots \ldots \ldots$

XI. DEVLATION EROM RULES........................ 6

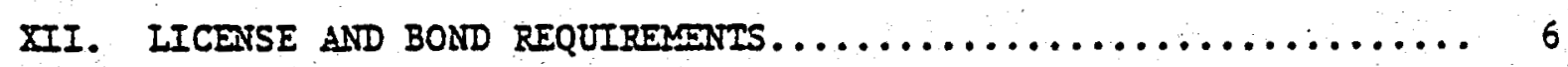

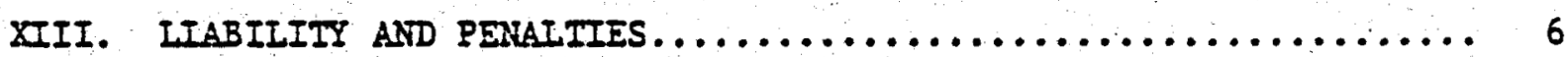

XIV. EFFECIIVE DATE AND DURATION OF REGULATION............. 6 
Keguacion No. $0-1$

COLORADO DEPARTMENT OF AGRICULTURE

RULES AND REGULATIONS

BEGARDIYG PROCESSED ANIYAL WASTE PRODUCTS

I. Legal Authority: :

Iitle 35, Article 60, Section 107, Colorado Revised Statuces 1973, as amended.

II. Definitions:

A. "Antial Waste" means a product composed of excreta, with or without bedding marerials and/or andmal drigs, and collected from poultry, rominants, or other antmals, except bumans.

B. "Processed Antmal Waste Product" means a processed anlmal waste product.

C. "Processed", as applied to antmal waste, means thermally dehycirated, dry stacked, ensiled, oxdazed, chemically treated, wicrobiologically digested, chemtcally or physleally fractlonated, or treaced by other processes which ofll enable the product to comly with the standards set forth in Section V. A. 2.

D. "Dried Poulity Waste (DPW)" means a processed animal weste product composed of feces from comerclal poultry, which bas been themally dehydrated to a wolsture content not in excess of 12.00 gercent.

E. "Drfed Poulery Ifteer" weans a processed animal waste product composed of a processed combination of feces from comerefal poultry together with lleter that was present in the flock production of pouley. wich has been thermally dehydrated to a molsture content not in excess of 12.00 percent.

F. "Dried Rumbant Waste" means a processed antmal waste product composed of processed ruminant excreca wht has been themally dehydrated to a molsture content not in excess of 12.00 percent.

G. "Uadrled Processed Animal Waste Product" means a processed animal waste product composed of excreta, with or wh thout litter, from poulerl, ruminants or other animal and which contatos in excess of 12.00 percent moisture.

E. "Processed Antmal Waste Derivative" weans a product resultiog from the complete chemical or microblological alteration of an arimal waste. The product mist be free of the orfginal unaltered enimal waste except moisture. Examples of processed antmal waste derfvatives are yeasts, algae or other organisms produced and barvested from non-buman animal wastes. The specific name of eaci such animal waste derivative product must be descriptive and be approved by the Comissioner of dgrficuleure before being registered or offered for sale. 
II. Definitions (continued):

I. "Person" means an individual, corporation, partnership, association, or any other business entity.

J. References to statuces or agency rules or zegulations shall mean the statute or rule or regulation as they may be amended subseguent to the adoption of these rules and regilations.

III. Registration Required:

No person shall sell, offer or expose for sale, or distribute, in this state, any processed animal waste product intended, promoted, represented, advertised or distrlbuted for use as a commercial feed as defined in Article 60 , Title 35, C.R.S. 1973 , prior to registering same with the Cowntssioner of Agrlculture.

IV. Registration Procedure:

A. Application for registration shall be made to the Comissioner on forms provided by the comissioner, and shall be accompanied by payment of the statutory registration fee as set forth in Section 35-60-105, C.R.S. 1973.

B. Applications for registration shall be accompanied by the following:

1. A certified copy of the label or tag reguired by section 35-60-104, C.R.S. 1973, which the applicant proposes to use for the processed animal waste product.

2. A detalled description, in affidavit form, of the facilities, equipment, and method of manufacture to be used in the processing, manufacturing, and testing of the processed animal waste product, $a$ sampling schedule and a full descrlption of all tests made, and the resuits, thereof purporting to show the processed animal waste product neets the standards of these rules and regulations for registration.

3. Upon request of the Comissioner of Agriculture, a sealed paciage of the processed animal waste product, containing at least one pound of the processed animal waste product to be sold, offered or exposed for sale, or distributed, in this state, together with the apelicant's affidavit that said sample is representative of the processed animal waste product offered for registration.

\section{Registration Refused:}

A. General: Registration of a processed animal waste product will be refused if:

1. Applicant or the processed animal waste product is determined to be in violation of any federal or Colorado statute or Colorado agency rule or regulation affecting or relating to the sale of comercial feeds. 


\section{v. Reg1stration Refused (continued):}

2. The processed antmal waste product contains any pathogenic organisms, drag residues, pestictde residues, harmful parasites, or other toxic or deleterious substances above levels permitted by Section 35-60-102 (1) (a) (b) (c) (d) (e), C.R.S. 1973, Federal Food, Drug, and Cosmettc Act, Sections 406, 408, 409, and 706, agency rules or agency regulation or which could be harmill to antrals, or which could result in residue in the tissue of byproducts of antmals of a level determined and promulgated by the Commissioner of Agriculture to be harmfulf; or which contains aflatoxins in excess of 20 ppb; or whtch contains more than a total of $500 \mathrm{ppm}$ as mercury, lead, blsmuth, copper, cadmium, arsenic, antimony, or eld.

3. The processed antmal waste product does not meet the Quality standards as set forth in section $\nabla I$ of the rules.

4. The processed waste product is oot labeled in compllance with law, including agency rules and regulations, tocluding Section VII of these rules.

B. Registration way be refused pursuant to and to compllance with any statutory provistons authorizing the Commissfoner of Agriculeure to refuse registration.

VI. Qualiey Standards:

A. No processed animal waste product shall contain ang extraneous materials such as, but not limited to, metal, glass, wire or aails, except as set forth in Seceloa $\sqrt{I}$ (D) (4) or (E) below.

B. Dried Poultry Waste sball not contalo

1. Less than 20.00 percent crude protein, or

2. In excess of 15.00 percent crude fiber, or

3. In excess of 30.00 percent ash, or

4. In excess of 1.00 percent seathers, or

5. In excess of 12.00 percent molsture, or

6. In excess of 20.00 percent litter.

C. Drfed Poultry Lftter shall not contatn

1. Less than 18.00 percent crode prote1n, or

2. In excess of 40.00 percent cride fiber, or

3. In excess of 30.00 percent ash, or

4. In excess of 5.00 percent feathers, or

5. In excess of 12.00 percent no1s ture.

D. Drfed Ruminant Waste shall not contaln

1. Less than 12.00 percent crude protelo, or

2. In excess of 30.00 percent crude fiber, or

3. In excess of 30.00 percent ash, or 
VI. Quality Standards (continued):

4. In excess of 40.00 percent straw, wood, wood shavings, Iitter, dirt, sand, rocks or other similar extraneous materials, or

5. In excess of 12.00 percent moisture.

E. Undried Processed Animal Wasce Products shall not contain in excess of 40.00 percent straw, wood, wood shavings, litter, dirt, sand, rocks or other extrameous materlals.

F. Any product labeled as or containing dried animal waste products shall be 12.00 percent moisture or less to aid in maintatnieg stable microbiological quality.

VII. Labeling Requirements:

A. General: The label or tag required by Section 35-60-104, C.R.S. 1973, shall, in addition to being in compliance therewith, stace:

1. If the product contains drugs, then the label should contain the following statement in boldface type at least one-half as large as any other type appearing on the label:

(a) "WARNITG: TEIS PRODUCT CONTAINS DRUG RESIDUES. DO NOT USE WIIIIN 30 DAYS OF SIAUGGTER AND DO NOT USE 30 DAYS PRIOR TO OR DURTNG TEE FOOD RRODUCTION PERIOD OF DAIRI ANIMALS AND IATING EENS."

(b) If the product contains high levels (15 ppm or greater) of copper: "WARNING: CONTAINS HIGE LEVELS OE COPPER: DO NOT FEED TO SEEEP."

2. In percentages in the following order:

(a) minimum protein

(b) maximum equivalent crude protein from non-protein nitrogen

(c) minimum fat

(d) maximin Eiber

(e) maximum ash

(f) maximum and mioimum calcium (Ca)

(g) mirim phosphorus (P)

(b) maximum sodium (Na)

(i) maximim molsture

(j) maxtmin 1ignin, if the processed animal waste product is Dried Poultry Ifter and if the product contains wood-based bedding materlals.

(k) maximm copper (Cu), if the processed animal waste product is Dried Poultry Waste or Dried Poultry Litter and does not contaio the wanting "DO NOT EEED TO SEIEEP".

3. The ravinum percentage, and ype, of processed animal waste prodict, when used in mixed feed.

4. As part of the product ame, the animal source and product type. 
VIII. Testing Required:

A. Any person seektig or receiving reg1stratton of any processed antmal waste product shall test, by representative sampling and assaytog of such samples, and keep accurate records thereof, the processed artmal waste product for which registration is sought or received, at least as of ten as required by the combissloner. The manufactrrer shall do such additional testing to assure that products are noncontaminated as set forth by the Colorado Feeding Stuffs: Law, Artelele 60 , T1tle 35, C.R.S. 1973, and the Rules and Regulations of the Food and Drug Aduinistration.

B. The sample shall be of suffictent size so as to provide meaningful data statlstically rellable in carrytog out the purpose of such sampling and analysis.

C. The purpose of such sampling stall be to detemire the presence of any materials specified in Section 7.2 and compliance with the Quality Standards as set forth in Secton VI of these rules in the processed arimal was te product.

IX. Records Required:

Any person seeking or receiving registration of ang processed antral waste product shall keep for a per1od of two (2) years, accurate records of:

A. All sources of raw materials and date acquired.

B. All production, fncluding a code or other method to 1dentify the date of produceion.

C. All sales and distribution, lncluding the name and address of the purchaser or to whom distributed, date, quantify and production code.

D. Sampling and assay records of the testeng requifed by Section VIII of these rules.

I. Begtstration Revocation, Suspension, Annulment, Limitation or Vodification:

A. Procedure: The procedures as spectified in arefele 4 of Iftle 24, C.R.S. 1973, for revocetton, suspension, smulment, I1nftation or wodification of licenses shall be followed in any proceeding to take any such actions with tegard to the registration of any processed animal waste product.

B. Grounds:

1. In addition to the specific provistions berein, the registration of any processed antmal waste product shall be subject to revocation, suspens10n, annulment, Ifritation, or modification pursuant to any statutory proviston directing or auchortztog such action with ragard to an agency license, as Iicense is defined in Sect10z 24-4-102 (7), C.R.S. 1973 .

2. The registration of any processed aninal wasta product detennined 
x. Registration Revocation, Suspension, Annulment, Limitation or Modification (continued):

(a) to be in violarton of any federal or Colorado statute, or Colorado agency rule or regulation affecting or relating to the sale of comercial feeds; or

(b) to be in violation of the standards specified in Sections $\nabla, \nabla I$, or VII of these rules;

shall be subject to being revoked, suspended, annuled, limited or modified as may be deemed appropriate by the Comissioner of Agricsleure.

3. Fatlure of any person to perform the testing as specified in section VII of these ries, or to accurately maintatn and display to the Combisstoner of Agriculture or the Comissioner's designee upon demand, the records required to be matntained as specified in Section Ir of these rules, shail be grounds for revocation, suspension, annulment, limitation or modification of the registration of any affected processed animal waste product, as may be deened approprlate by the Comissioner of Agrlculture.

'XI. Deviation Fron Rules:

For good cause shown, if not contrary to statute and if determined by the Combissioner of Agriculture not to pose a canger to the public, the Commissloner of Agrlculture, upon writeen request, may permit deviation fror these rules insofar as the Combissioner of Agriculture finds compliance therewith to be impossible, impracticable or unieasonable for any person or persons.

XII. Ifcense and Bond Reguirenents:

None.

XII. Llability and Peralties:

Prescribed by statute, Iitle 35, Article 60, C.R.S. 1973, as amended.

IIV. Effective Date and Daration of Regulation: To becone effective on November 19,1975 


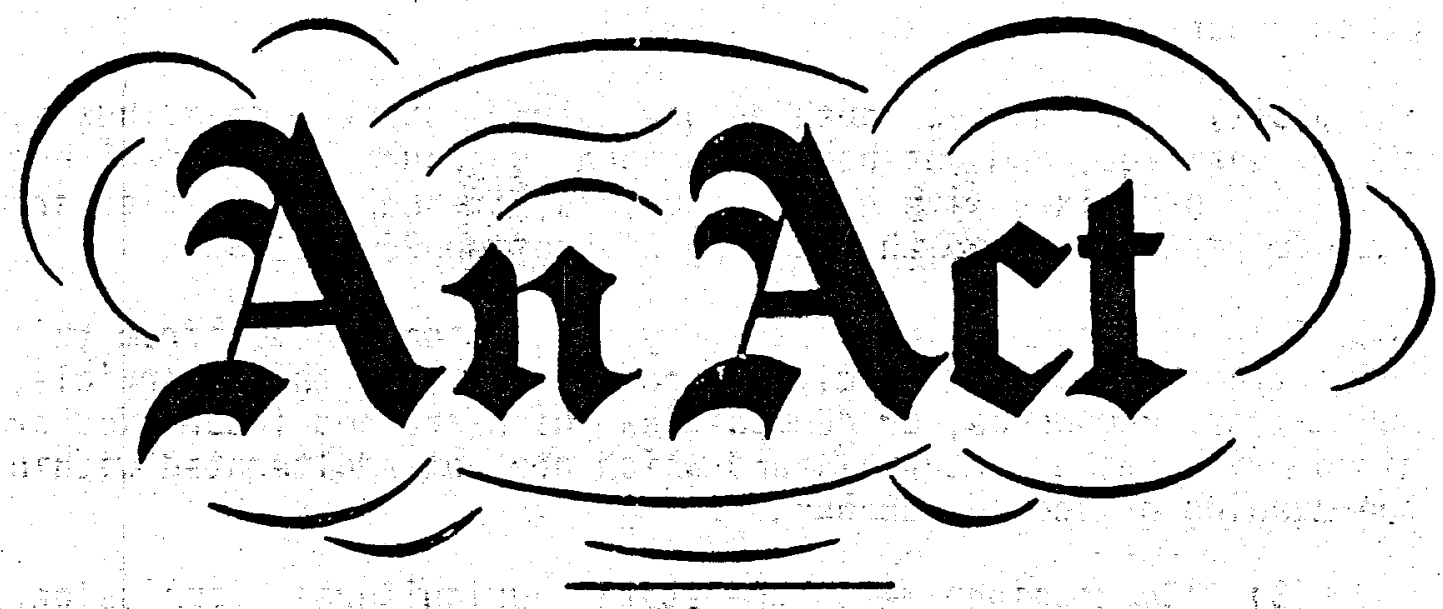

HOUSE BILL NO. 1368. BY REPRESENTATIVES Younglund, Burns, Hinman, Powers, DeNier, Hamlin, Hastings, Hudson, Showalter, Theos, and Winkler; also SENATORS Clark, Anderson, Soash, and Woodard.

CONCERNING COMMERCIAL AGRICULTURAL FEEDS.

Be it enacted by the General Assembly of the State of Colorado:

SECTION 1. Article 60 of title 35, Colorado Revised Statutes 1973, is REPEALED AND REENACTED, WITH AMENDMENTS, to read:

\section{ARTICLE 60}

\section{Commercial Feeding Stuffs}

35-60-101. Short title. This article shall be known and may be cited as the "Colorado Commercial Feed Law of 1979".

35-60-102. Definitions. As used in this article, unless the context otherwise requires:

(1) "Brand name" means any word, name, symbol, or device, or any combination thereof, identifying the commercial feed of a distributor or registrant and distinguishing it from that of others.

(2) (a) "Commercial feed" means all materials which are distributed for use as feed, or for mixing in feed, for animals other than human beings; except that "commercial feed" shall not include:

(I) Unmixed whole or processed seed made directly from the entire seed and not aduiterated within the meaning of section 35-60-106;

(II) Individual chemical compounds when not mixed with

Capital Tetters indicate new material added to existing statutes; dashes through words indicate deletions from existing statutes and such material not part of act. 
other materials;

(III) Commodities such as hay, straw, stover, cobs, husks, huils, ensilage, and wet beet pulp when unground and witen not mixed or intermixed with other materials, if such commodities are not adulterated within the meaning of section 35-60-106.

(b) The commissioner may, by regulation, exempt from this definition, or from specific provisions of this aricicle, substances, compounds, or commodities which are not internixed of mixed with other materials and which are not adulterated within tile meaning of section 35-60-106.

(3) "Commission" means the state agricultural comrisision.

(4) "Commissioner" means the commissioner of agricu?tura or his authorized agent.

(5) "Contract feeder" means a person who, as an indeperident rontractor, feeds commercial feed to poultry and animals pursuant co a contract whereby such commercial feed is manufactured by such person for poultry and animals other than those owned oy such person or whereby such commercial feed is supplied, furnished, or otherwise provided to such person and whereby any part of the remuneration of such person is determined by feet ronsumption, poultry or animal mortality, profits, or anount or quality of product.

(6) "Customer-formula feed" means a feed which consists of a nixture of commercial feeds or feed ingredients:

(a). If all or any part of such feed is furnished by the person or distributor who processes, mixes, mills, or otherwisa prepares such mixture;

(b) If such mixture is prepared according to the specific instructions of the final purchaser, with or without a guaranteed analysis of protein, vitamin, mineral, drug, or other nutritive. components the purchaser specifies the feed shall contain; and

(c) If the feed is distributed only to the customar who requested it and is not redistributed.

(7) "Department" means the department of agriculture and includes the state agricultural commission, the commissioner of agriculture, and all employees and agents of the department.

(8) "Distribute" means to:

feed;

(a) Offer for sale, sell, exchange, or barter commercial

(b) Supply, furnish, or otherwise provide commercial feed 
to a contract feeder.

(9) "Distributor" means any person who distributes commercial feed.

(10) "Drug" means any substance intended for use in the diagnosis, cure, mitigation, treatment, or prevention of disease in animals other than human beings and substances other than feed intended to affect the structure or any function of the animal body.

(11) "Federal Food, Orug, and Cosmetic Act"1" means the "Federal Food, Drug, and Cosmetic Act", 21 U.S.C. sec. 301 et. seq. (1938), as amended.

(12) "Feed ingredient" means each of the constituent materials making up a commercial feed.

(13) "Label" means a display of written, printed, or graphic matter upon or affixed to the container in which a commercial feed is distributed or the invoice or delivery slip distributed with a commercial feed.

(14) "Labeling" means all labels or other written, printed, or graphic matter:

(a) On a commercial feed, its containers or wrapper; or

(b) Accompanying a commercial feed.

(15) "Manufacture" means to grind, mix, blend, or further process a commercial feed for distribution.

(16) "Metric ton" means one thousand kilograms or two thousand two hundred four and sixty-two hundredths pounds.

(17) "Mineral feed" means a commercial feed primarily intended to supply mineral elements or inorganic nutrients.

(18) "Official sample" means a sample of feed taken by the comissioner or his agent in accordance with the provisions of section 35-60-110. weights.

(19) "Percent" or "percentages" means percentages by

(20) "Pet" means any domesticated animal normally maintained in or near the household of the owner.

(21) "Pet food" neans any commercial feed prepared and distributed for consumption by pets.

(22) "Product name" means the name of the commercial feed 
which identifies it as to kind, class, or specific use.

(23) "Raw agricultural commodity" means aliy reed ingredierit in its raw or natural state.

(24) "Specialty pet" means any domesticated arimal pet normally maintained in a cage or tank, including, but not limited to, gerbils, hansters, canaries, psittacine birds, mynahs, finches, tropical fish, goldfish, snakes, ard turtles.

(25) "Specialty pet food" means any romercial feed prepared and distributed for consumption by specialty pets.

(26) "Ton" means a net weight of iwo thousand pounds avoirdupois, or 907 tonnes metric equivalent.

35-60-103. Registration. (1) (a) No percon shall distribute in this state a commercial feed, eirep: customer-formula feed, which has not been registered pu'suent to this section. An application for registration shall be submitt $=d$ to the comnissioner in the manner he prescribus. If the application is approved by the commissioner, a registration shal" be issued to the applicant.

(b) All registrations shall expire on December il of eacn year, and a registration shall continue in offect from the ine of issuance until it expires, unless cancelled b; the registrail or unless cancelled pursuant to subsection (4) of lhis sectisil by the commissioner.

(2) (a) The following fees for registiation shall te paid to the commissioner:

(I) Registration and reregistration of each product......

(II) Changes in registration..............\$2.00

(b) A distributor shall pay a registration fee of ten dollars for each commercial feed product, except customer-formula feed distributed only in individual packages weighing ten pounts or less, and the distributor of such product shall not be required to pay the inspection fee on such packages of the product so registered.

(c) The fees required by this subsection (2) shall be deposited in the state treasury and credited to the general fund.

(3) The commissioner may refuse registration of any commercial feed not in compliance with the provisions of this article and may cancel the regisration of any commercial feed which is not in compliance with the provisions of this article; except that no registration shall be refused or cancelled until 
the registrant has been given an opportunity to be heard before the commissioner and to amend his application in order to comply with the requirements of this article.

(4) When a distributor is located outside of Colorado and is distributing commercial feed in Colorado, such distributor shall maintain, for at least two years, the records and information required by this section and section 35-60-104 and upon request shall furnish the commissioner with a certified audit performed by a recognized auditing firm. The commissioner may cancel all registrations of any person who fails to comply with this requirement.

35-60-104. Labeling. (1) A comercial feed, except a customer-formula feed or feed produced by a contract feeder, shall be accompanied by a label bearing the following information:

(a) The net weight or liquid volume when metered through an approved metering system;

(b) The product name and the brand name, if any, under which the commercial feed is distributed;

(c) The guaranteed analysis of the commercial feed, stated in such terms as the commissioner may require by regulation to advise the user of the composition of the feed or to support claims made in the labeling of such feed. In all cases the composition of the feed must be determinable by laboratory methods published by the association of official analytical chemists or by such other methods as are acceptable to the commissioner.

(d) The common name of each ingredient used in the manufacture of the commercial feed; except that the commissioner by regulation may permit the use of a collective term for a group of ingredients which perform a similar function, or he may exempt commercial feeds from this requirement of an ingredient listing if he finds that such listing is not necessary to protect the interests of consumers;

(e) The name and principal mailing address of the manufacturer or the distributor;

(f) Adequate directions for the use of a commercial feed which contains drugs and for the use of such other feeds as the commissioner may deem necessary for their safe and effective use;

(g) Such precautionary statements as the commissioner determines are necessary for the safe and effective use of the commercial feed.

(2) A customer-formula feed shall be accompanied by a 
label, invoice, delivery slip, or other shipping document which identifies the feed as a customer-formula feed. A copy of the specifications of any customer-formula feed, if not furnished the customer at time of delivery, shall be on file at the manufacturing facility.

35-60-105. Mislabeling. (1) A commercial feed is mislabeled if:

(a) Its labeling is false or misleading in any particular;

(b) It is distributed under the registared nane of another commercial feed;

(c) It is not labeled as required by section 35-60-104;

(d) It is represented as a commercial feed or is represented as containing a commercial feed ingredient and such commercial feed or feed ingredient does not conform to the definition of such feed or feed ingredient, if any, prescribed by regulation by the commissioner.

(e) Any word, statement, or other information required by or pursuant to this article to appear on the label or labeliing is not prominently placed thereon with such conspicuousness, as compared with other words, statements, designs, or devices in the labeling, and in such terms as to render it likely to bro road and understood by the ordinary individual under customary conditions of purchase and use.

35-60-106. Adulteration. (1) A commercial feed shall be deemed to be adulterated if:

(a) It bears or contains any poisonous or deleterious substance which may render it injurious to health, but if the substance is not an added substance, such commercial feed shall not be considered adulterated if the quantity of such substance in the feed does not ordinarily render it injurious to health;

(b) It bears or contains any added poisonous, deleterious, or nonnutritive substance which is unsafe within the meaning of section 406 of the "Federal Food, Drug, and Cosmetic Act", other than a substance which is a food additive or a pesticide chemical in or on a raw agricultural commodity;

(c) It is, bears, or contains any food additive which is unsafe within the meaning of section 409 of the "Federal Food, Drug, and Cosmetic Act";

(d) It is a raw agricultural commodity and it bears or contains a pesticide chemical which is unsafe within the meaning of section 408 (a) of the "Federal Food, Drug, and Cosmetic Act"; except that where a pesticide chemical has been used in or on a 
raw agricultural commodity in conformity with an exemption granted or a tolerance prescribed under section 408 of the "Federal Food, Drug, and Cosmetic Act" and such raw agricuitural commodity has been subjected to processing such as canning, cooking, freezing, dehydrating, or milling, the residue of such pesticide chemical remalning in or on such processed feed shall not be deemed unsafe if such residue has been removed to the extent possible in good manufacturing practice and if the concentration of such residue in the processed feed is not greater than the tolerance prescribed for the raw agricultural commodity, unless the feeding of such processed feed will result or is likely to result in a pesticide residue in the edible product of the animal which is unsafe within the meaning of section 408 (a), of the "Federal Food, Drug, and Cosmetic Act".

(e) It is, bears, or contains any color additive which is unsafe within the meaning of section 706 of the "Federal Food, Drug, and Cosmetic Act".

(f) Any valuable constituent has been wholly or partially omitted or abstracted therefrom or any less valuable substance substituted therefor;

(g) Its composition or quality falls below or differs from that which it is represented by its labeling to possess;

(h) It contains a drug and the methods used in or the facilities or controls used for its manufacture, processing, or packaging do not conform to current good manufacturing practice regulations promulgated by the commissioner to assure that the drug meets the requirement of this article as to safety, and it has the identity and strength and meets the quality and purity characteristics which it purports or is represented to possess. In promulgating such regulations, the commissioner shall adopt the current good manufacturing practice regulations for medicated feed premixes and for medicated feeds established pursuant to the "Federal Food, Orug, and Cosmetic Act" unless he determines that such regulations are not appropriate to the conditions which exist in this state.

(i) It contains viable weed seeds in amounts exceeding the limits which the commissioner shall establish by regulation.

35-60-107. Prohibited acts. (1) The following acts and the causing thereof within the state of Colorado are prohibited and shall be punished as provided in section 35-60-112 (1):

(a) Manufacture or distribution of any commercial feed that is aduiterated or misbranded;

(b) Adulteration or misbranding of any commercial feed;

(c) Distribution of agricultural commodities such as whole 
seed, hay, straw, stover, silage, cobs, husks, and hulls which are adulterated within the meaning of section 35-60-106;

(d) Removal or disposal of a commercial feed in violation of an order under section 35-60-111;

(e) Failure or refusal to register in accordance with section 35-60-103;

(f) Violation of section $35-60-112$ (6);

(g) Failure to pay inspection fees and fipe report. as required by section $35-60-108$.

35-60-108. Inspection fees and reports. (1) To raise additional revenue to defray the expenses of inspection, sampling, analysis, and other expenses necessary for the administration of this article, an inspection fee not to exceed twenty cents per ton on all comnercial feeds, including feed ingredients defined pursuant to section 35-60-109 as commercial feeds, produced or distributed in this state shall be paid to the comissioner by the person who produces or distributes the commercial feed; except that:

(a) No fee shall be paid when inspected on rustomer-formula feed or feed which is produced by a contract feeder and used only in his feeding operation and except that commercial feeds used therein are not exempt from inspection fees. Customer-formula feed shall be subject to inspection pursuant to section 35-60-110 and no fee shall be charged. Inspection, sampling, and laboratory services shall be provided by the department at the request of producers of customer-formula feed, producers of contract feed, or the customer of these provisioners. The requestor shall pay for these services according to fees set forth in regulations issued by the commissioner.

(b) No inspection fee shall be paid on commercial feed if such fee has been paid by a previous distributor of the feed.

(c) Credit shall be allowed for payment of the inspection fee on commercial feeds which are used in the manufacture of other commercial feeds.

(d) An annual registration fee of ten dollars for each calendar year shall be paid pursuant to section $35-60-103$ (2) (b) on a commercial feed which is distributed in the state only in packages of ten pounds or less in lieu of the inspection fee provided by this subsection (1).

(2) The per ton rate of the inspection fee may be adjusted by the commissioner, upon recommendation from a five-nember committee comprised of representatives of the feed, livestock, and poultry industries, so that the fee collected shall cover the 
cost of inspection, sampling, and analys is and shall not exceed that necessary to meet reasonable expenses for the administration of this article. Notice of any change in the rate of inspection fee shall be given to all registrants not later than sixty days prior to the beginning of the reporting period, pursuant to paragraph (a) of subsection (4) of this section, to which such change shall apply.

(3) Invoices or other shipping documents accompanying feed ingredients which are defined as commercial feeds shall state in legible form that the inspection fees imposed by this section have been paid.

(4) Each person who is liable for payment of an inspection fee pursuant to this section shall:

(a) Not later than the last day of January and of July of each year, file a semiannual statement reporting the number of. net tons of comercial feed distributed in this state during the preceding six-month period; except that an instate manufacturer may elect to file on the net tons of commercial feed produced during the preceding six-month period;

(b) Upon filing such statement, pay the inspection fee on such feed. Inspection fees which have not been remitted to the commissioner within fifteen days following the due date shall be assessed a penalty of twenty-five dollars or the amount of the inspection fee, whichever is smaller. Such penalty shall be added to the inspection fee imposed pursuant to this section and shall be paid when such fee is paid. Assessment of a penalty pursuant to this paragraph (b) shall not preclude the commissioner from taking any other action against the producer or distributor of such feed which is authorized by this article.

(c) Keep such records as are necessary to accurately show the tonnage of commercial feed manufactured or distributed in this state. Such records shall be maintained for at least two complete fiscal years, and the commissioner shall be permitted to examine the records to verify statements of tonnage.

(5) Faflure to make an accurate statement of tonnage, to pay the inspection fee, or to comply with the provisions of this article and regulations promulgated pursuant thereto shall be sufficient cause for cancellation of all registrations of the distributor which are on flle with the commissioner.

(6) All fees and other moneys collected pursuant to this section shall be deposited in the state treasury and credited to the general fund.

35-60-109. Commissioner - authority. The commissioner shall promulgate, amend, and repeal, in accordance with the provisions of the "State Administrative Procedures Act", article 
4 of title 24, C.R.S. 1973, such regulations as are necessary for the enforcement of this article, and, in the interest of uniform regulation, shall by regulation adopt the official definitions of feed ingredients and official feed terms adopted by the association of American feed control officials as published in the official publication of such association and the regulations promulgated pursuant to the "Federal Food, Orug, and Cosmetic Act" ; except that if the commissioner determines that any of such definitions, terms, and regulations are inconsistent with the provisions of this article or are not appropriate to conditions in this state, he shall not adopt them.

35-60-110. Inspection, sampling, and analysis. (1) (a) To enforce the provisions of this article and regulations adopted pursuant thereto, the comissioner, upon presenting appropriate credentials to the owner, operator, or agent in charge, may enter and inspect, at reasonable times and during normal business hours if possible, within reasonable 1 inits, and in a reasonable manner, any factory, warehouse, or establishment within the state in which commercial feeds, feed ingredfents, or raw agricultural commodities for use in such feeds are manufactured, processed, packed, or held for distribution, and any vehicle being used to transport or hold such feeds, feed ingredients, or raw agricultural commodities, and may obtain samples of such feeds, feed ingredients, or raw agricultural commodities. Each inspection shall be commenced and completed with reasonable promptness, and, upon completion of the inspection, the person in charge of the facility or vehicle shall be so notified.

(b) If such entry, inspection, or sampling is denied or not consented to and no emergency exists, the commissioner is empowered to and shall obtain from the district or county court for the district or county in which such premises, property, or vehicle is located a warrant to enter and inspect such premises, property, or vehicle and to sample such commercial feeds, feed ingredients, or raw agricultural commodities prior to entry, inspection, and sampling. The district and county courts of this state are empowered to issue such warrants upon a proper showing of the need for such entry, inspection, and sampling. Any information concerning any method, records, formulations, or processes which is entitled to protection as a trade secret and which is obtained in the course of the inspection or sampling shall be kept confidential.

(2) (a) Sampling and analys is shall be conducted in accordance with methods published by the association of official analytical chemists or in accordance with other generally recognized methods.

(b) The results of all analyses of officlal samples shall be forwarded by the commissioner to the person named on the label and to the purchaser. If the inspection and analys is of an official sample indicates a commercial feed, other than 
customer-formula feed, has been adulterated or misbranded, the commissioner shall furnish to the registrant, upon request made within thirty days following receipt by the registrant of the analysis, a portion of the sample concerned.

(c) In determining whether a commercial feed is deficient in any component, the commissioner shall utilize a sample obtained in accordance with the provisions of this section.

35-60-111. Detained commercial feeds. (1) When the commissioner or his authorized agent has reasonable cause to believe any lot of commercial feed is being distributed in violation of any of the provisions of this article or of any regulations promulgated pursuant thereto, he may issue and enforce a written or printed "withdrawal from distribution" order, warning the distributor not to dispose of the lot of commercial feed in any manner until written permission is given by the commissioner or the court. Within five days of the issuance of any such order, the commissioner shall hold a hearing to determine whether the order was correct. If the original withdrawl order was in error, the commissioner shall immediately release the lot of commercial feed so withdrawn. If the original withdrawl order is found to be correct, the commisstoner shall release the lot of commercial feed so withdrawn when said provisions and regulations have been complied with. If compliance is not obtained within thirty days, the commissioner may begin, and upon request of the distributor or registrant. shall begin, proceedings for condemnation.

(2) In no case shall the commissioner issue a "withdrawal from sale". order unless he furnishes, upon request, a sample of the feed or label believed to be in violation to the manufacturers or distributors involved.

(3) Any lot of commercial feed not in compliance with the provisions of this article and regulations promuigated pursuant thereto shall be subject to seizure on complaint of the commissioner to a court of competent jurisdiction in the area in which said commercial feed is located. In the event the court finds the comercial feed to be in violation of this article and orders the condemnation of said commerclal feed, it shall be disposed of in any manner consistent with the quality of the commercial feed and the laws of the state; but in no instance shall the disposition of said commercial feed be ordered by the court without first giving the claimant an opportunity to apply to the court for release of said commercial fee or for permission to process or relabel said commercial feed to bring it into compliance with this article.

35-60-112. Penalties. (1) Any person convicted of violating any of the provisions of this article or who impedes, hinders, or otherwise prevents, or attempts to prevent, the commissioner or his duly authorized agent in performance of his 
duty in connection with the provisions of this article is guilty of a misdemeanor and, except as provided in subsection (6) of this section, upon conviction thereof, shall be fined not less than one hundred dollars nor more than two hundred fifty dollars for the first violation and not less than two hundred dollars nor more than five hundred dollars for a subsequent violation.

(2) Nothing in this article shall be construed as requiring the commissioner or his representative to report for prosecution, to institute seizure proceedings, or to issue a withdrawal from distribution order, as a result of minor violations of this article when he believes the public interest will best bi served by suitable notice of warning in writing.

(3) It is the duty of each district attorney to whom any violation is reported to cause proceedings to be instituted where appropriate and prosecuted in a court of competent jurisdiction without delay. Before the commissioner reports a violation for such prosecution, an opportunity shall be given the distributor to present his views to the commissioner.

(4) The commissioner is hereby authorized to apply for and the court to grant a temporary or permanent injunction restraining any person from violating or continuing to violate any of the provisions of this article or any rule or regulation promulgated under this article, notwithstanding the existence of other remedies at law, said injunction to be issued witholit bond.

(5) Any person adversely affected by acts of the commissioner or regulations promulgated pursuant to this article may have recourse through the procedures of the "State Administrative Procedure Act", article 4 of title 24, C.R.S. 1973.

(6) Any person who uses any information acquired under the authority of this article concerning any methods, records, formulations, or processes which are entitled to protection as trade secrets to his own advantage, or reveals such information to any person other than the commissioner, other state officials, or the courts when relevant in any judicial proceeding is guilty of a misdemeanor and, upon conviction thereof, shall be punished by a fine of not less than one hundred dollars or by imprisonment in the county jail for not less than thirty days, or by both such fine and imprisonment; except that this prohibition shall not be deemed to prohibit the commissioner from exchanging information of a regulatory nature with duly appointed officials of the United States government or of other states, if such officials are prohibited by law from revealing the information.

35-60-113. Cooperation with other entities. The commissioner may cooperate with and enter into agreements with governmental agencies of this state, other states, agencies of the federal government, and private associations in order to 
carry out the purpose and provisions of this article.

35-60-114. Publications. The conmissioner shall publish at least annually, in such form as he may deem proper and in accordance with fiscal rules promulgated by the controller pursuant to the provisions of section 24-30-208, C.R.S. 1973, information concerning the sales of commerclal feeds, together with such data on their production and use as he may consider advisable, and a report of the results of the analyses of official samples of commercial feeds sold within the state as compared with the analyses guaranteed in the registration and on the label; but the information concerning production and use of comnercial feeds shall not disclose the operations of any person.

1, 1979.

SECTION 2. Effective date. This act shall take effect July

SECTION 3. Safety clause. The general assembly hereby finds, determines, and declares that this act is necessary for the immediate preservation of the public peace, health, and safety.
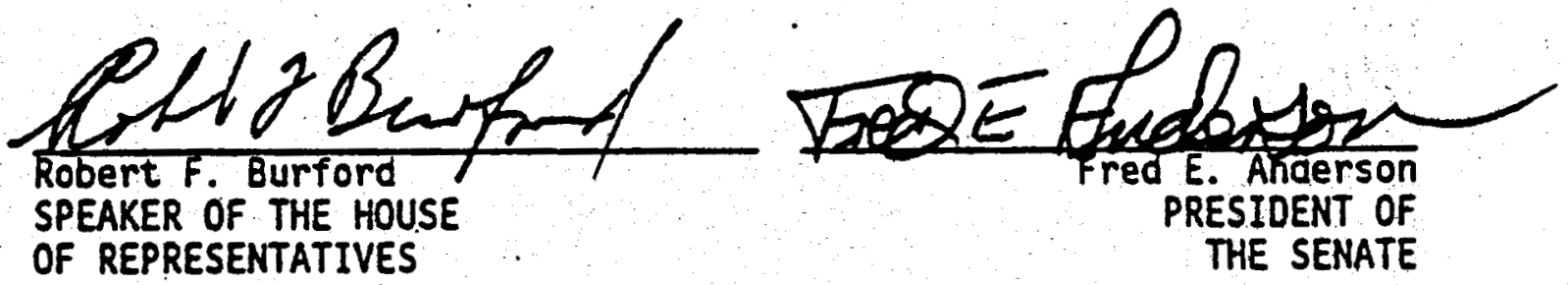

PRESIDENT OF

THE SENATE
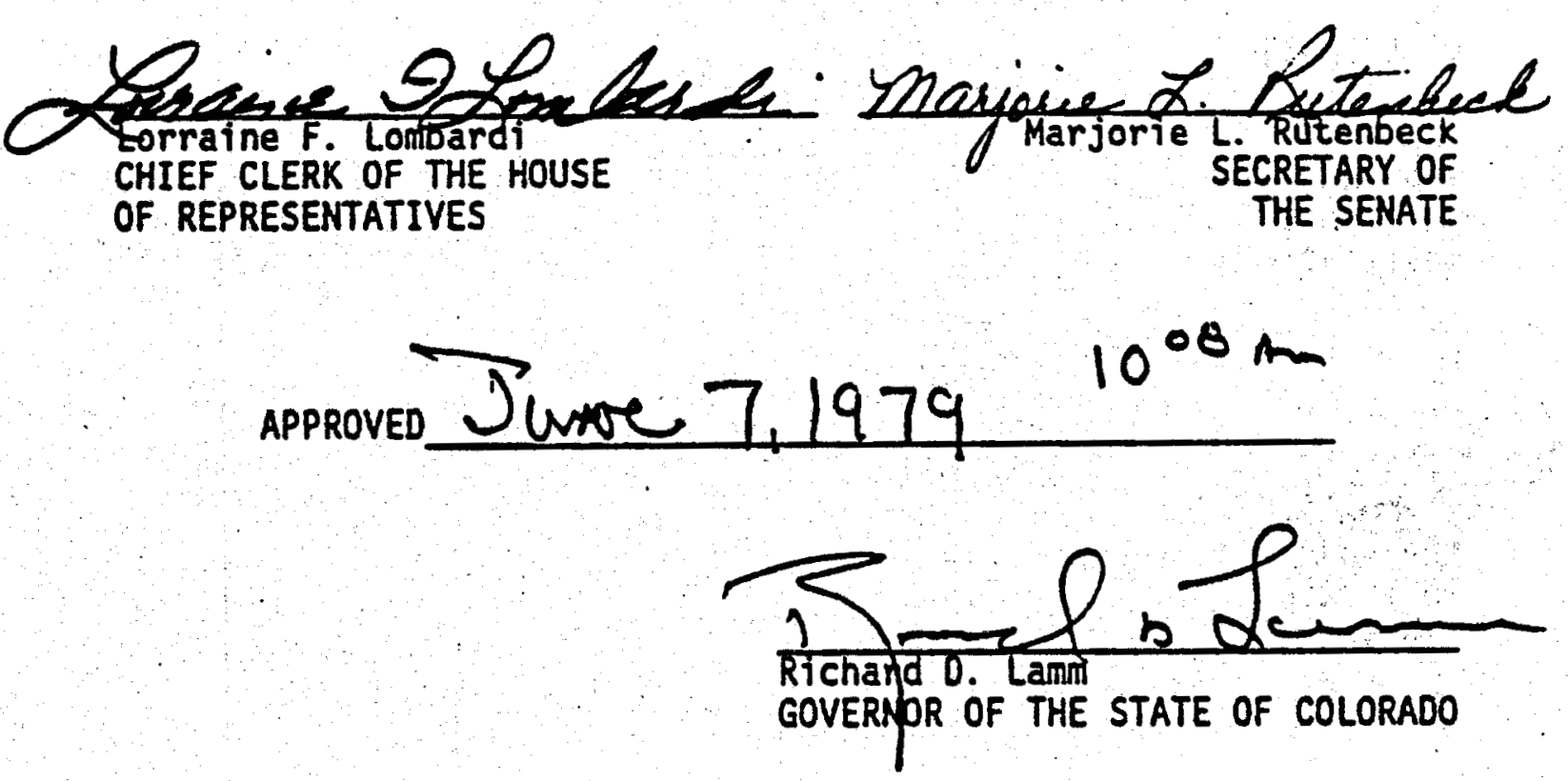
$\therefore-\therefore-\cdots \Xi$

PR 161380

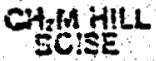

\section{COMMERRLLI ANTMAL FEEDS}

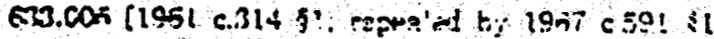

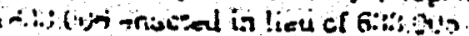

633.005 Detinitions for ORS 635.005 to 633.089. As used in ORS 633.006 to 633.089 and 633.992 , unless the context requires otherwise: means:

(1) "Anomal feed manufacturing plant"

(a) Any busiress, establishment, building, plant or place where commercial feed for animals is manufactured, mired, processt or packed:

(b) Vehicles used in transportiog commer cial feed or components or ingredients thereof, machinery, equiprest, utensils, implements, or other items, articles or enaterials used in the business or operatior.

(c) The ground upon which the operation or business is carried out and other ground not adjacent thereto which is a part of the business or operation under the same entity or ownership.

(2) Brand" means any word, name, symbol or device or any combination thereof adopted or used by a person to identify commerrial feeds manufactured compounded. delivered, distributed, sold, offered for or exposed for sale in this state and to distin. guish then from commercial feeds manufac. tured dirtributed, offered for sale or sold by others.

(3) "Bulk" is the sale, offering or exposing for sale or delivery of commereial feeds, in:

(a). Open containers, closed or open tnte boxes, closed or open tanks, closed or open trailers, all of which way be further described or defined by the departurent, or

(b) Othier types of containers, vehicles or conveyances defined or recognized by the departiment.

(4) "Comnsercial feed" means any material which is distributed for use as feed, or as a feed ingredient for mixing in feed for arimals, or any feed additive concentrate, feed additive supplement, feed additive premix, or premix, except:

(a) Unmixed seeds, whole or processed, made dirently from the entire seed.

(b) Hay, straw, stover, cobs, husks, screenings and hulls, when ungrousd or unnixed with other materials. (c) Feed for dojs, cats, birds or fish maictuined as household peis.

(d) Silago of matarials containing at least. 60 $p=r$ cert of rater.

(e) Individual chemical compounds when oot mixed with other maiarial. Tri- exerption, hovever, doss not cover of extend to phosphate, urea or ammoniun compouads which are recurrienderl for anieal fendisg purposes.

(5) "Contrant foedar" means an indsoeadeat contractur, or any other person who feeds comrorrial feed to asirals pursuant to an oral or snittan agroement titergby such corcenercial feed is supplied, furcished or otherwive provided to such person by any distributor and whereby such gerson s remuneration is detarnined all or in part by feed consurption, mortality, profits, or anount or quality of product it does not ieclude a bons fide explnye of a manufacturer or distributor of corrisercial fe-

(6) Customer-forrala feed," "custoen mix" or "custcm mixed feed" means eny mixture of materials, substances or ingredieatu described or set forth under the definition of cormercial faed, each lot of which is mired according to the specific instractions of, or prescribed for the specific use of, the firal corsumer or feeder. For the purpose of this subsection "final consumer" means a person who owns or who contracts for the feeding of en imals under the control or ownership of that person.

(7) Departmeni" means the State Department of Agriculture.

(8) Distribute" means to offer for sale, sell or barter, cormercial fesd or eustomer. forrula fecid or to supply, funish or otherwise proside commerisil or customer-formula feed as a contrat feeder.

(9) "Distributor' means acy ferson who distributes.

(10) "Drug" or "drugs" means any substance intended or represtented for the cure, mitigation, treatrent or prevention of disease of animels, or intended to affect the structure of any function of the cody of an aninal or as prescribed by the deportment.

(11) "Feed ingredient" means each of the constituent materials mating to a commer cial feerl.

(12) "Ground" means a condition resulting from eruhing, rol!ing. chnpping or grinding.

(I3) "Label" messs a disolay of uritten. printed, or graphic matter upos or affixed to the container, or immetiate container, in which a commercial lewt is diatrihn. $\rightarrow$ ow a. an 
comrercial fesd or cuitwer formula fed is distributent.

(14) "Manufacture's means to grind chop, crush, roll, cube, flake, excrude, cook, pelletize, mix or otherwise process feed ingredients.

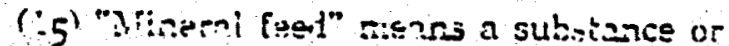

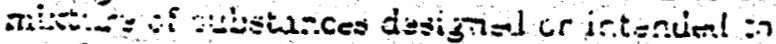
suppiy primiarily mineral elements or inorgas: ic nutrients.

(16) "Official sample" means any sample of feed taken by the department and designated as "official" oy it.

(LT) "Percent" or "percentage" means percentige by weight.

(18) "Sell" or "sale" includes exchinge. [1967 c.591 \$2 (eancted in lieu of 633.005): 1973 c342 \$2! 1979 . 116,51 .

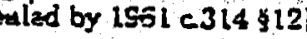

60.011 [1507 c.59l 310; seperled by 1971 c.489 \$11]

633.015 Registration of commercial feed required; fee. (1) No person shall distribute a nonregitered commercial feed. Every brand, acd each formula or fortinulation thereof, of commercial feeds manufactured, compoundis, delivered, distributed, sold, oftered or exposed for sale is this state shall be registered with the departerent. ApplicaLun for registration shall be sibmitted on forms furnished by the departonent, and, if the deparment so reguests, shsll be accompanied by the label or a facsimile of the label and other printed metter describing the product. Upon approval by the department, a certificate of registration shall be furmished to the applicant. All registrations expire on Decernber 31 of each year. The apolication shall include the information required by para. graphs (b), (c), (d) and (e) of subsection (1) of ORS 633.0'25 and such other information as the department may require:

(2) A distributor shall not be required to register any brand of commercial feed which has been regivtared under ORS 6.33.006 to 633.089 and 633.592 by another persoa.

(3) Changes in the guarante of either chemical or ingredient composition of a registered commercial feed may" be permitted, if there is satisfactory evidence that such changes would not result in 2 lowering of tine fevling value of the proluct for the purixist for which designed.

(4) The department may refuse registration of any commercial feed when the application is not in compliance with the provisions of O.SS 6.33.006 in 6.33.089 and 6.33.992 and may cancel any registration subsequently fourd not to b- in compliance with any penvi, sion o? ORS 6.33.AD6 to 6.3.3.039 and 633.99.2, afte- the registrant has betn given ressoivable oppormity ti be heard before the devartment and to amend his application in order to comply with the requirements of ORS 633.006 to 633.089 and 633.992 .

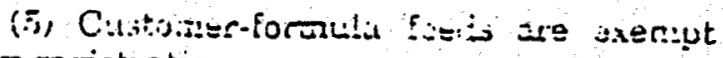
from registration.

(6) Each apolication for registration shall be accompanied by a fee to be establisbed by the department not to exceed $\$ 20$ for each formula or formulation of commercial feed under each brand.

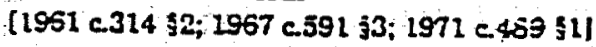

Ex3.020 [Reaunled by $1961 \mathrm{c} 31+\xi 12]$

633.025 Labeling requirements. Any commercial feed distributed in this state shall be acconoanied by a legible label bear. ing the following information:

(a) The net weight.

(b) The name or brand under which the commercial feet is sold.

(c) The guaranteed analysis of the corsmercial feed, listing the minimum percentage of cride protein and cude fat, and the marimum percentage of crude fiber. For mineral feeds the list shall include the following specifications as to minerals present, expressed as herein indicated: Minimum and maximum percentages of calcium (Ca), minimum percentaze of phosphorus (P), minimurn percentage of iodine $(1)$, and minimum and maximurn percentajes of salt (NaCl). Other substances or elements, determinable by laboratory methods, may be guaranted by permission of the department. When other substances or elements are guaranteed, they shall be subject to inspection and analysis in accordance with methods and regulations preseribed by the department. Products sold solely as mineral or vitamin supplements, or both, need not show guarantes for protein, fat or fiber.

(d) The common or usual name of each ingredient used in the manufacture of the commercial fed, except as the departmeat may, by regnlation, permit the use of a collective term for a group of ingredients all of which perform the same furction or, by regulation, permit the use of a statement of alternative ingredients of comparable feeding va!ue. In lieu of the common or usual name of each ingredient used, or a collective tern for a group of ingredients, or a scatement of alter. nutive ingredients, a statement may be made. that the ingredients used in the mianufactire of the commercial feed are in accordance with the registration with the depirtment, and such list of ingredients shall te made avail- 
(a) The name and principal business address of the se on responsible for distributing the commercial Fer 1.

12) When a commercial feed is distributed in this st te in bags or other containers, the label shall llaced on or affixed to the container; when a - ommercial feed is distributed in bulk the label sf 11 accompany delivery and be furnished to the 3 haser at time of delivery. Containers of comnerclal feed not containing a drug are exempt from th labeling provisions of this section when such ad ainers are filled in the presence of the purch-ser from retall bins or other retall bulk display crintars if such bins or bulk display containers a) labeled with the information otherwise reguired to se present on individual packages of such feed.

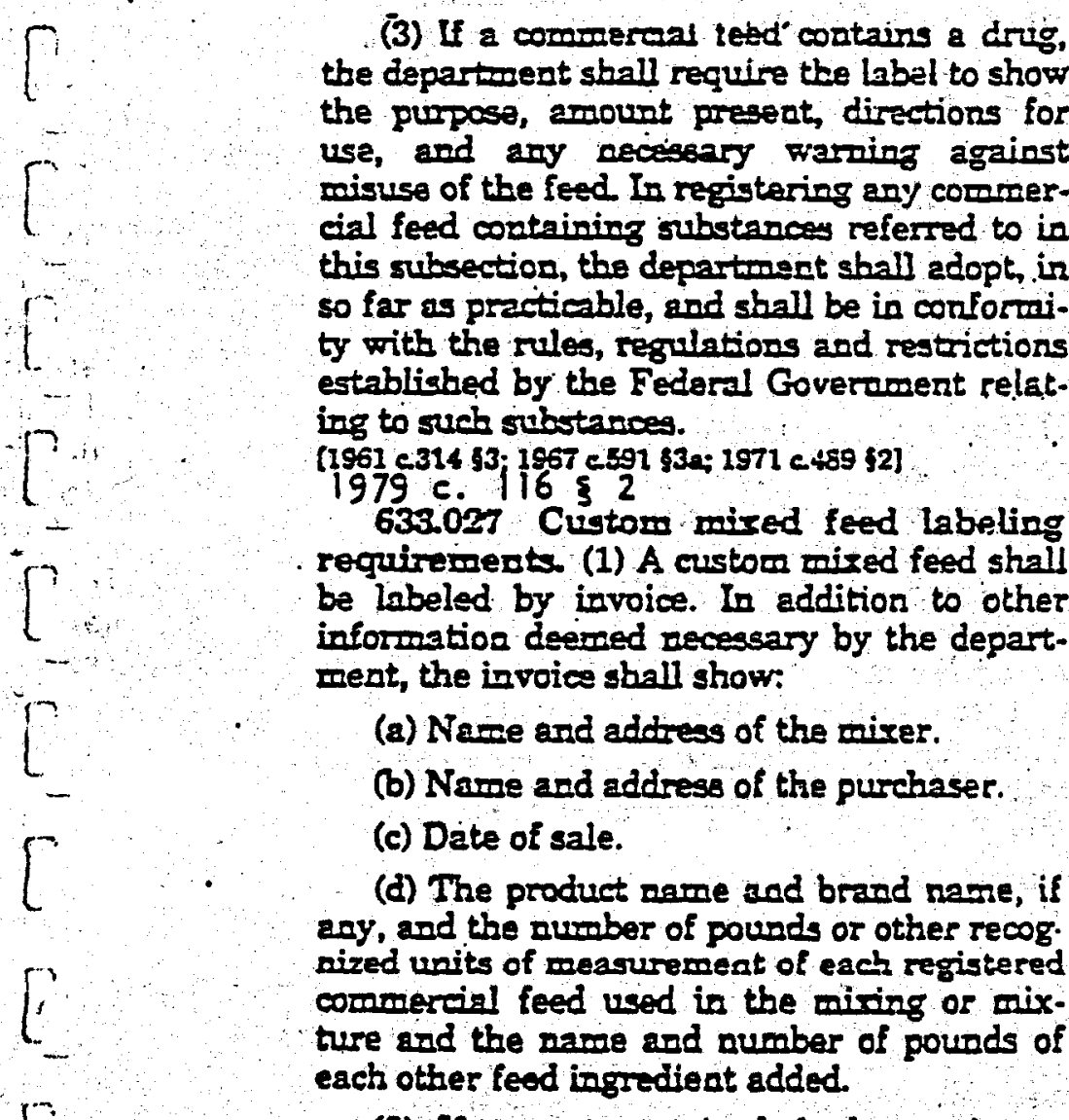

(2) If a custom mixed feed contains a conoutritive substance which is intended for use in the diagnosis, cure, ritigation, treaturent, or prevention of disease or which is intended to affect the structure of any function of the arienal body, the depatment may require the label and the invoies to show:

(a) The arrount of the substance present.

(b) The directions for use and warnings against mivuse of the feed.

(3) The invoice or information prescribed in this section shall be furnished by the seller to the user or purchaser at the tire the cus. tom orixed feed is delivered. The records of the seller from which the invoice and informa. tion is derived shall be maineained by the seller for a period of at least two years. Such tr. a purchaser, may be inspected by the department during business hours.

[1967 c.591 \$9]

633.029 Registration required for animal feed manufacturers and sellers: exemption for persons not using drugs in feeds. (1 (a)o person shall operate an animal feed manufacturing plant, distribute commercial feeds other than at retail, be furnished a certificate of registration of a brand in this state, distribute a custom-formula feed manufactured for that person, or repackage or relabel a comercial feed manufactured by another person without having first obtained a license fron the department. Application for license shall be on forms prescribed by the deparment and shall be accompanied by a license fee to be established by the department not to exceed $\$ 500$. All licenses shal1 expire December 31 of each year.

(b) In accordance with the provisions of ORS 183.310 to 183.500, the department may promulgate rules desigaating different Ilcense fees for yarious categories of persons described in paragraph (a) of this subsection, so as to recognize differences in types of activities or volumes of business.

(2) (a) A person who is a contract feeder is not sublect to the provisions of subsection (1) of this sectlon, provided no drugs in any form are utilized in the manufacturing, wixing or processing of such feed. In the event drugs are so utilized, the contract feeder or person using the same shall be subject to the provisions of subsection (1) of this

(b) In accordance with the applicable provisions of ORS 183.310 to 183.501 . the department shall promulgate rules designating the types or categories of persuns described in paragraph (a) of this subsection to whom this section applies. In promulgating such rules, the department shall consider:

(A) The methods of manufacture, mixing or processing of feed used:

(B) The quantities and kinds of drugs used; and

(C) The number, ages and kinds of animals to which such feed is to be mad oivail. able.

\{1971 c.489\$? 1973 c.342 \$3i 1979 c. 166 \& 3

63.3.037 Records required of licensees; records inspection by departre st. A person or cuntract feeder who manu? a:s:ures, mixes or processes feets in which drigs have been used so that he is not exempt fon the provisions of ORS 633. 291, shall mai in an accurate record for at le ast one year swe st the $467^{d}$ 
or identity of each dug so used and its level of usage. The department is authorized to inspect the records of such persons to insure complience with ORS 633.029 and this section

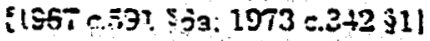

E33040 [Repealed by 1957 c 314 S12]

633.045 Adulteraied commercinl feds probibited No person shall distribute an aduiterated cormercial feed. A comorercial feed shall be deemed to be adultariated.

(1) If any poisonous, deleterious or nonnutritire ingredient is therein present in sufficient amount to render it injurious to health when fad in accordanos with directions for use shown on the label.

(2) If any raluable constituent bas been in whole or in part omitted or absuracted there irom or any less valuable substance substituted therefor.

(3) If its composition or quality falls below or differs from that which by its labeling it is purportad or represented to posseiss.

(4) If it contains added hulls, screenings, reruze screenings, straw, cobs or other high ficer material, unless the name of each material is stated on the label.

(5) If it contains pesticide residues or other chemicals in ercess of amounts which, by regulation, the department declares safe for feeding purposes. In adopting such regulations the departsent may take into consideration the commonly permitted amounts of cinscricals authorized by:

(a) The United States and other states.

(b) Other recognized agencies or organizations experienced in the chemical field.

(6) If it containg a drug other than those permitted by regulations promulgated by the departreat. In proenigating such regulations the department shall consider the current goud manufacturing practice regulations for medicated feed premixes and for rredicated feeds established under authority of the Federal Food, Drug and Cosmetic Act.

[1661 c 314 85; 1971 c489 \$3]

ExS.050 (Peperied by $1951 \mathrm{c} 314 \mathrm{b12)}$

633.055 Misbrandiog commercial feed prohibited. No person shall distribute unisbrendes commercial ieed. A commercial feed shall te deemed to be misbranded:

(1) If its labeling is false or misleading in
(2) If it is distributed under the nane of another feed.

(3) If it is not labeled as required by ORS 633.025 and by regulations adopted pursuant to ORS 633.006 to 633.089 and 633.992.

(1) Li it purforts to be or is represented as a feed ingredient or as contrining a feed ingredient, unless such feet ingredient conforms to the definition of identity, if any, prescribed by regulation of the department. In adopting such regulations the department may take into consideration the commonly accepted definitions approved or authorized by:

(a) The United States and other states.

(b) Other recognized agencies or organizations experienced in such roatters, such as the Association of American Feed Control Officials.

(5) If any word, statement, or other information required by ORS 633.006 to 633.080 and 633.992 or by regulation of the department to appear on the label is not prominently placed thereon with such conspicuousuess, as corrpared with other words, statements, desigas, or devices in the labeling, and in such terms as to render it likely to be read and understood by the ordinary isdividual under customary conditions of purtiase and use.

[1961 c.314 \$6]

023.080 [Amended by 1951 c425 \$17; repeeled by 1961 e.314 \$12\}

633.065 Department to test comorercial feeds. (1) It shall be the duty of the department to sample, inispect, make analyses of, and test commercial feeds distributed within this state, at such tiries and places and to such an extent as may be necessary to determine whether or not such feeds are in compliance with the provisions of ORS 633.006 to 633.089 and 633.992. The department is authorized to enter upon any public or private premises, ircluding any vehicls of transport, during regular business hours, in order to have access to commencial feeds and to records relating to their distribution.

(2) The methods of sampling and analysis shall be those adopted by the department. In adopting such methods, the departrnent may take into consideration:

(a) The methots scientifically developed and described in recognized official publications such as the Journal of the Association of Official Agricultural Chemists.

(b) The methods ansroved bv the United 
der, may be seized by the department in accordace with the provisions of ORS 561.605 to 561.620 .

โเ9TL c.4S4 \$ 9 !

bijori Ijscosition of moneys received by department The department shall deposit all fees and moneys paid to it under the provisions of ORS 633.006 to 633.089 and 633.992 in the General Fund in the State Treasury to the credit of the Department of Agrioultare Account. Such account, and all other moneys collected by the depart. ment under ORS 633.005 to 633.085 (1965 Replacerrent Part) prior to the effective date of this 1967 Act, are continuously appropriated to the department for the purpose of administering and enforring ORS 633.006 to 633.089 and 633.992 .

[L967 C.591 \$7]

as.000 [Repealed by 1961 c314 \$12]

623100 Repeuled by 1961 c.314 \$121

Es2110 Repealed by 1961 c.314\$121

E3.120 [Repealed by $1961 \mathrm{c} .314 \$ 121$

Ex3.130 [Fapealed by $1961 \mathrm{c} 314$ \$L2]

633.1 40 [Pepeaied by $1901 \mathrm{c.314} \$ 12$ ]

E3.210 [Pepealed by 1961 e314\$12]

033.200 [Repealed by 1961 - 314 \$12]

633200 [Repealed by 1961 c314\$12]

632240 (Repealed by 1961 c.314 \$12)

630.250 [Repealed by $1961 \mathrm{e} 314$ \$12]

E53.250 (Repeeled by 1951 c314 \$12) 


\section{AMENDMENTS TO OAR 603-58-065}

License Fees for Feed Manufacturers, Wholesale Distributors, Feed Registrants and Certain Feeders.

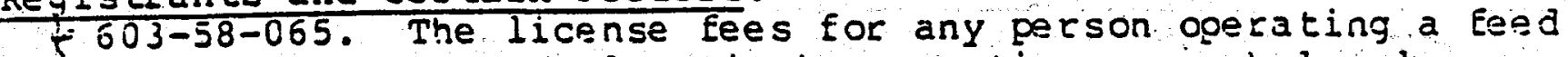
manufacturing plant (per location), or acting as a wholesale distributor of feeds, or registering feeds for distribution in oregon, or acting as a contract feeder where in drugs in any form are utilized in the manutacturing of such feed, shall be in accordance with the following:

(1) A license fee of $\$ 50$ for:

(a) Feed Registrants who do not maintain feed manufacturing plants in Oregon; or

(b) Wholesale Distributors who are ne ither Eeed Manufacturers or Feed Registrants.

(2) A license fee of $\$ 100$ for:

(a) Feed Manufacturers, whe ther Contract Feeders or otherwise, whose annual production of commercial feed at one location is less than 10,000 tons;

(b) Feed Registrants who maintain feed manufacturing plants in Oregon whereat the annual production of commercial feed is less than 10,000 tons; or

(c) Contract Feeders who are not also Feed Manufacturers.

(3) A license fee of $\$ 200$ for:

(a) Feed Manufacturers, whether Contract Feeders or otherwise, whose annual production of commercial feed at one location is at least 10,000 tons but less than 25,000 tons; or

(b) Feed Registrants who maintain feed manufacturing plants in Oregon whereat the annual production of comnercial feed is at least 10,000 tons but less than 25,000 tons.

(4) A Iicense fee of $\$ 300$ for:

(a) Feed Manufacturers, whe ther Contract Feeders or otherwise, whose annual production of commercial feed at one location is 25,000 tons or more; or

(b) Feed Registrants who maintain feed manufacturing plants in oregon whereat the annual production of commercial feed is 25,000 tons or more. 
1 HERESY CERTIFY that the altachad copy is a true, iu.l and correct copy ct rula(s) adopied by the State Department of Agriculture (Asine?) on October 17, 1979

become eifesive upon filing

(Dais)

The within matter having come berore the State Department of Agriculture as AD 14-79 proeedurez having been in the required form and conducted in ascordance with zpplieabla siatuies and rules and being dised in the premises:

NOWN THEREFORE, IT IS HERESY ORDERED THAT th: foliswing rule(s) be: (list Rule Number(s) or Rule Tille on Appropria:e Lines Selow)

Adopied:

(Nises Rulas)

Anended:

(Exizting Rules)

OAR 603-58-065 in accordance with Exhibit "A" attached hereto.

Suspendad:

(Tenforary Only)

P:pezied:

(Existing Rules)

2

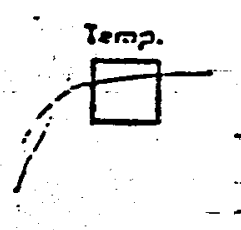

idininistrative pules of the

State Department of Agriculture DATED this 17th day of October

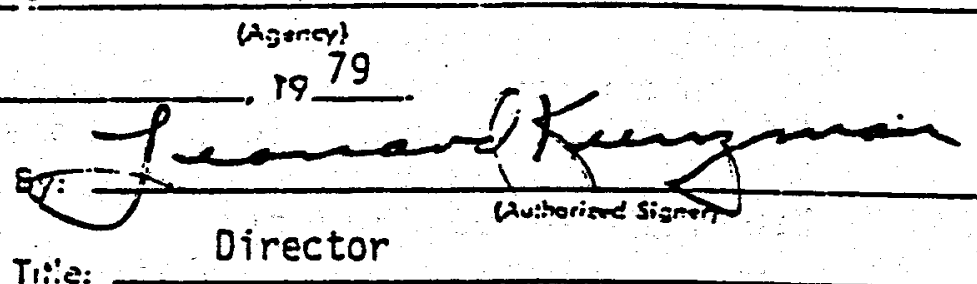
isey Authoring:

ORS 561.190 and 633.029 , as amended by section 3 of chapter 116, Oregon Laws ac: Alatiat:

To provide different license fees for various catecories of animal feed manufacturers or distributors, recognizing the various types and volumes of bustness activities. 
DIVISION 58

\section{FEEDS}

4

Defintitiens

-603-58-001 In addition to the definitions set forth in ons 633.006 , the rollowing shall apply to ORS 633.015 to 633.089 and OAR 603-58-005 to 603-58-070:

(1) "Feed Additive Concentrate" means a substance which is:

(a) Intended to be further diluted and uned in order to produce a complete feed or a feed additive supplenent;

(b) not sultable for using as a supplewent or for direct feeding without dilutIon; and

(c) contains amounts of one or more feed additives, in a sultable feed base, so that from 100 to 1000 pounds of concentrate must be diluted in order to produce one ton of complete feed.

Note: It is unsafe if fed directly and undliuted or $1 f$ used as a supplement, elther because of the danger to the health of the animal or because of the production - f residues in excess of established safe levels in the edible products from such animals.

(2) "Feed Additive Supplement" means a substance which contalns one or more feed additives and which is intended to be:

(a) further diluted and mixed in order to produce a complete feed; or

(b) red undiluted as a supplewent to other feeds; or

(c) fed directly and undiluted with other parts of the rations separately avallable.

NoTE: It is safe for the animal and will not produce dangerous levels of residues in the edible products from such animals if red according to directions.

(3) "Feed Add1t1ve Premix" means a substance whlch:

(a) Is Intended to be further diluted in order to produce a feed additive concentrate, a feed additive supplement, or a complete reed; and

(b) contains one or more feed additives 14 nigh concentration and in a suitable feed base, so that up to 100 pounds wust be diluted to produce one ton of complete
Nots: It contains additives at levels for wh1ch safety to the animal has not been demonstrated, and if fed undiluted may result in residues in excess of established safe levels in the edible products from such antmals.

(4) "Medicated Feed" means a commerclal feed in combination with a drug; as defined In subsection (10) of ORS 633.006 .

(5) "Llquid Feed" means a commerclal feed of fluid or liquid conslstency containing one or more feed ingredients, as defined in subsection (11) of ORS 633.006 and subsection (6) of this section.

(6) "Feed Ingredsent" weans any material as defined in subsection (11) of ORS 633 . 006 that provides nutritional benerits to the target species, but does not include anti-caking agents, color additives, condiments, grinding agents, pelleting agents, plgmentors, or stabliling agents.

(7) "Vitamin Feed" means a comerclal feed designed or lntended to supply primarily vitamins, vitamin derivatives, or vitamin precursors.

Statutory Athority:

H1st: Filed and Eff. 2-3-76 as AD 1080(4-76)

Form of labeling

603-58-002 The information required by subsection (1) of ORS 633.025 and OAR 60358-005 to 603-58-031 shall appear in its entirety on one side of a label or container. Such information shall be legible and not subordinated to other statenents, nor obscured by designs, color, Insuff1clent background contrast, or crowding with other graphic matter.

Statutory Authority:

H1st: Filed and Eff, $2-3-76$ as AD $1080(4-76)$

Labeling as to Brands and Product Names

603-58-005 (1) Unless the department speclflcally designates otherwise, the product names and standards for commerclal feeds shall be those adopted by the American Feed Control officlals as set forth in their publication entitled "officlal publication" dated 1974. 
(2) The brand or product name shall not be misleading. If the brand or product name indicates the feed is for a specific use or purpose, the character of the feed shall conform therewth (1.e., a mixture labeled "dafry feed" shall be suitable for feeding datry animals).

(3) The brand or product name of a nonmedicated feed shall not be derlued from one or more ingredients of a mixture to the exclusion of other ingredleats, nor shall be one representing any component of a m1xture unless all components are included in the name.

(4) The word "vitamin", or contraction thereor, or any word suggesting vitamin content, shall only be used in the brand or product name of a feed which is represented to be a vitamin supplement, and which is labeled with the guarantee prescribed in subsection (3) of OAR 603-58-010.

(5) The name of any drug or drug add1tive, or contraction thereof, or any word suggesting a drug or drug additive content shall only be used in the brand or product name of a feed which is represented to be a drug or drus additive supplewent, and which is labeled with the guarantee prescribed in subsection (2) Of OAR 603-58-010.

(6) The term "dehydrated" may precede the product name if such product has been art1flcially dried.

[Publications: The publication(s) referred to or incorporated by reference in this rule is avallable in the orflce of the Department of Agriculture or Secretary of State.]

Statutory Authority:

Hist: Filed 12-5-62 as AD 715 , Eff. $1-1-63$

Renumbered from 603-26-051

Amended by $A D$ 1080(4-76),

Filed and Eff. 2-3-76

\section{Labeling as to Guarantees}

$603-58-010$ (1) The sliding-scale wethod of expressing guarantees (1.e., protein 15185) is prohibited, unless specifically provided for by applicable law or rule.

(2) Drugs in commercial feeds shall be quantitatively guaranteed in terms of percentage by welght. Antibiotics in commerclal feed shall be quantitatively guaranteed in terms of grams per pound for all products which are to be diluted before reeding, and in terms of grams per ton in all products which are to be fed without further dilution or mixing. If the dosage is given in terms of ullilgrams per day in the feeding directions, the antibiotics may be guaranteed in terms of cilligrams per pound.

(3)(a) Vitamins, when guaranteed in commercial feeds, shall be quantitatively guaranteed in terms of milligrams per pound of feed, except that vitamin $A$ other than precursors of vitamin $A$, vitamin $D$, and vitamin $E$ shall be in terms of International or USP units per pound, and vitamin $D$ in products offered for poultry feeding shall be in terms of International chlck units.

(b) Such guarantees of vitamin content shall be in terms of true vitamins rather than compounds with the exception of the compounds, Pyridoxine Hydrochloride, ChoIIne Chloride, Thiamine, and d-Pantothenic Acid.

(c) Such guarantees, if on olls and premixes containing vitamin $A$ or vitamin $D$ or both, way be in terms of units per gram.

(4) Minerals in comercial feeds when guaranteed, except salt ( $\mathrm{NaCl})$, shall be quantitatively guaranteed in terms of percentage of the element. Salt shall be guaranteed as $\mathrm{NaCl}$.

(5) In addition to the requirements set forth in ORS 633.025 , Ilquid feeds shall be quantitatively guaranteed for:

(a) minimum percent of total sugars expressed as invert sugar;

(b) maximum percent of ash; and

(c) maximum percent wolsture.

Statitory Authority:

H1st: Filed $12-5-62$ as $A D 715$, Eff. $1-1-63$

Renumbered from 603-26-055

Amerided by $A D$ 1080(4-76), Filed and Eff. 2-3-76.

603-58-015 [F1led $3-18-68$ as AD $870(3-68)$, Eff. $4-1-68$ Renumbered from 603-26-06i Repealed by AD $1080(4-76)$, Filed and E[f. 2-3-76]

Labeling as to Inzredients

603-58-020 (1) Each Individual ingredient 
shall be specifically named by its common - usual name, without reference to the lallty or grade thereof.

(2) In lieu of individual ingredient statement prescribed in subsection (1) of this section, the following collective terms for the specifled groups of ingreglents may be used:

(a) "Animal Protein Products" which includes one or more of the following:
(A) Animal products;
(B) Marine products;
(C) Milk products;

(b) "Eorage Products" which includes one or more of the following:
(A) Alfalfa meals;
(B) Ent1re plant meals;
(C) Bays;
(D) Stem meals;

(c) "Grain Products" which Includes one or wore of the following:
(A) Barley;
(B) Grain sorghums;
(C) Maize (corn);
(D) Oats;
(E) Rice;
(E) Rye ;
(G) Wheat.

(d) "Plant Protein Products" which includes one or more of the following:
(A) Algae meals;
(B) Coconut meals (copra);
(C) Cottonseed meals;
(D) Guar meal;
(E) LInseed meals;
(E) Peanut meals;
(C) Safflower meals;
(B) Soybean meals;
(I) Sunflower meals;
(J) Yeasts.

(e) "Processed Graln By-Products" which includes one or more of the followlng:
(A) Brans;
(B) Brewers drled grains;
(C) Distillers grains;
(D) D1stillers solubles;
(E) Flours;
(F) Germ weals;
(G) Gluten feeds;
(H) Grits;
(I) Groats;
(J) Hominy feeds;
(K) Malt sprouts;
(L) Middlings;
(M) Pearled;

(N) Polishings;

(O) Shorts;

(P) Wheat w111 run.

(f) "Roughage Products" which Includes one or more of the following:
(A) Cobs;
(B) Hulls;
(C) Husks;
(D) Pulps;
(E) Straws.

(3) In lieu of the ingredlent statements prescribed in subsections (1) and (2) of this section, a statement may be made that the ingredients used in the manufacture are In accordance with the registration with the department, but only if such registration shows the following groups:

(a) Corn, hominy feed, wheat, barley, and grain sorghums;

(b) Cottonseed meal, soybean meal, peanut meal, linseed neal, and corn gluten meal;

(c) Fish weal, meat and bone weal, tankage, and poultry by-product meal;

(d) Beet molasses, corn sugar molasses, citrus molasses, and cane molasses;

(e) Wheat bran, wheat mill run, and wheat middlings;

(f) Wheat shorts, wheat red dog, corn germ meal, corn gluten reed, and grain sorghum gluten feed.

(4) The names of all Ingredients shall be shown in letters or type of the same size.

\author{
Statutory Authority: \\ Hist: Filed $3-18-68$ as $A D$ 870 $(3-68)$, \\ Eff. $4-1-68$ \\ Renumbered from 603-26-065 \\ Amended by AD $1080(4-76)$, \\ Filed and Eff. 2-3-76
}

\section{Labellng as to Drugs}

603-58-021 The labeling requirements of livestock and poultry feeds containing drugs, chemical antiblotics, or hormone additlves shall be those adopted and published by the Federal Food and Drug Admin1stration in Title 21, Code of Federal Regulations, effective as of the date of this order.

[Eublications: The publication(s) referred to or incorporated by reference in this rule is avallable in the office of the Department of Agriculture or secretary of State.] 
Statutory Authority:

Hist: Filed and Eff. $2-3-76$ as AD $1080(4-76)$

Labeling as to Nenorotein N1trogen

603-58-022 (1) Urea and ammonium salts of carbonic and phosphoric aclds shall only be used in uixed reeds for cattle, sheep, and goats. In mixed feeds for other purposes, such compounds shall be considered adulterants and the feed as adulterated under ORS 633.045.

(2) The statement of the maximum percentage of equivalent protein from nonprotein nitrogen shall appear immediately below the statement of crude protein in the chemical guarantee, and the name of the substance supplying the nonprotein nitrogen shall be stated in the ingredient statement.

(3) If the feed contains more than 3 percent of urea ( $8.75 \%$ equivalent crude pratein) or ammonium salts, or $1 f$ the equivalent protein contributed by urea or amonium salts exceeds one-third of the total crude proteln, the label shall also include:

(a) A statement of proper usage; and

(b) The following statement in type of such consplcuousness as to render it ilkely to be read and underetood by ordinary individuals under customary conditions of purchase and use:

\section{"CAUTION: USE AS DIRECTED"}

Statutory Author1ty:

H1st: Elled and Eff. 2-3-76 as AD $1080(4-76)$

603-58-025 [F1led 12-5-62 as AD 715 , Eff. $1-1-63$ Amended $12-17-69$ by AD $911(17-69)$, Eff. $1-1-70$ Renumbered from 603-26-071 Repealed by $A D$ 1080(4-76), Filed and Eff. 2-3-76]

\section{Labeling of Custom-Fomulated Feed}

603-58-028 In addition to the labeling requirements set forth in ons 633.027 , each container of custom-formulated feed shall have a label identifying the customer by elther name or order number (1.e., "C.M. Jones" or "CM 1234"). Where the delivery is by bulk, such label shall be attached to each delivery ticket.

Statutory Authority:

H1st: Filed and Eff. 2-3-76 as AD $1080(4-76)$

Labeling of Medicated Custom-Formulated Feed

603-58-029 In addition to the labeling requirements set forth in ORS 633.027 and OAR 603-58-028, each container of medicated custom-formulated feed shall have a label identifying the purpose of the drug ingredlent, the name of each active drug ingredient, and the amount of each drug ingredient. Any special feeding directions or withdrawal or caution statements shall also be included in the label.

Statutory Authority:

Hist: Filed and Eff. 2-3-76 as AD $1080(4-76)$

Labeling of Mineral Feeds

603-58-030 (1) Mineral phosphatic materlals for feeding purposes shall be labeled with a guarantee of the minimum percentages of calcium and phosphorus, and the maximum percentage of fluorine.

(a) The maximum percentage of fluorine in any mineral or wineral wixture for the direct feeding of domestic anlmals shall be 0.30 percent for cattle, 0.35 percent for sheep, 0.45 percent for swine, and 0.60 percent for poultry.

(b) Soft rock phosphate with colloldal clay, rock phosphates, or other fluorinebearing ingredients may be used only in such amounts that it will not raise the fluorine concentration of the total (grain) ration above the following amounts: 0.009 percent for cattle, 0.01 percent for sheep, 0.014 percent for swine, and 0.035 percent for poultry.

(2) Mineral feeds, and wixed feeds containing 8 percent or more added mineral ingredients, shall be labeled with a guarantee of the minimum and maximum, percentages of calclum ( $\mathrm{Ca}$ ) and salt ( $\mathrm{NaCl}$ ) and the 
minimum percentages of phosphorus $(P)$, and Ilne (I). The specifle compound shall be reted in terms of the form used. The minimum and maximum guarantees for calclum and salt shall conform to the following:

(a) If the minimum percentage 155 percent or less, then the maximum percentage shall not exceed the ninimum percentage by more than 1 untt (1.e, if ainimum 3 percent, then maximum 4 percent).

(b) If the minimum percentage is above 5 percent, then the maximum percentage shall not exceed the minimum percentage by more than 20 percent of such mimimum (1.e., if minimum 10 percent, then waximum 12 percent).

\section{Statutory Author1ty:}

Hist: E1led 12-5-62 as AD 715 , Eff. $1-1-63$

Renumbered from 603-26-076

Amended by AD 1080(4-76). Filed and Eff. 2-3-76

\section{Labeling of Processed Antmal laste}

603-58-031 Animal waste products sold, teld for sale, or offered for sale shall be Identified in accordance with the definitlons, and shall conform with the requiremeats of this section. Such products which are utllized for feeding on the premlses where produced, by the person whose animals produced the same, ahall conform gentally to the arovisions of this section.

(1) "processed animal waste" is a processed product composed of total excreta, with or without litter, from poultry or ruulnant aniwals. It shall not contain levels of drug residue, pestlclde residue, or other toxic or deleterious substances that could be harmful to animals or result in harmful or unlawful residue levels in their tissue or by-products. The rinal colsture of the product shall not exceed 12 percent, except as provided in subsection (2) or this section. It shall not be used in reed for lactating daing animals. If used in a mfred feed, the maximum percentage of procefugd animal waste shall be stated on the la of such alxed reed. It shall not be fed to animals within 15 dayo of slaughter. Processed anlmal waste includes the followLng: (a) "Dried Poultry Waste" 1s processed undiluted poultry excreta collected from cage layer flocks. The product shall be uniform and contain not less than 25 percent crude protein, not wore than 15 percent crude fiber, and not more than 30 percent ash. It shall be labeled to show minimum protein, maximum equivalent crude protein frow nonproteln nitrogen, minimum fat, maximum riber, maximum ash, maximum and minimum salt ( $\mathrm{NaCl}$ ), maximum and minimum calcium ( $\mathrm{Ca}$, and minimum phosphorus ( $P$ ). The product shall not contain more than 1 percent feathers.

(b) "Dried Poultry Litter" is the processed comblnation of total poultry excreta and litter that occurs in the floor production of poultry. The product shall be un1rorm and contain not less than 18 percent proteln. The type of litter shall be a part of the product name. It shall be labeled to show minimum protein, maximum equivalent crude protein from nonprotein nitrogen, minimum fat, maximum fiber, maximum ash, maximum and minimum calcium $(\mathrm{Ca})$, minimum phosphorus (f), and maxioum and minimum salt ( $\mathrm{NaCl}$ ).

(c) "Drled Ruminant Waste" is processed bovine excreta free of extraneous material such as straws, wood shavings, dirt, and slmilar materials. The product shall be uniform and contain not less than 12 percent crude protein and not more than 30 percent crude flber and 20 percent ash. It shall be labeled to show minlmum protein, maximum equivalent crude protein from nonproteln nitrogen, minimum fat, maximum flber, maximum ash, and maximum and minimum salt ( $\mathrm{NaCl}$ ).

(2) Processed Animal waste in excess of 12 percent molsture Including slurries, allages, and other semldry products shall conform to the requirements of subsection (1) of this section except for the molsture 1fmitation stated therein. If sold for feeding purposes, 1 t shall be labeled to show type of process, maximum molsture, minimum protein, maximum equivalent crude prote1n from nonproteln iltrogen, minimum fat, maximum flber, maximum ash, and maximum and minimum salt (NaCl).

Statutory Authority:

Hist: Filed and Eff. 2-3-76 as AD $1080(4-76)$ 
603-58-035 [Filed 3-18-68 as AD $870(3-68)$, Eff. $4-1-68^{\circ}$ Renumbered from $603-26-080$ Repealed by AD 1080(4-76), Filed and Eff. 2-3-76]

Methods of Sampling and Analysis

603-58-036 The methods of sampling and analysis shall be those adopted by and included in the "Journal of the Association of official Analytical Chemists", or any other method approved by the department.

[Publications: The publication(s) referred to or incorporated by reference in this rule is avallable from the office of the Department of Agriculture or Secretary of State.]

Statutory Authority:

Hist: Filed and Eff. $2-3-76$ as

AD $1080(4-76)$

\section{Artiflefial color}

603-58-040 An artificial color may only be used in commercial feeds if it has been recornized by the department as harmless to animals. However, no material shall be used to enhance or mask the natural color of a feed or feed ingredient if inferiority of the feed or feed ingredient would thereby be concealed.

Statutory Authority:

Hist: Filed 12-5-62 as AD 715, Eff. $1-1-63$

Renumbered from 603-26-085

Amended by $A D$ 1080(4-76),

Filed and Eff. 2-3-76

603-58-045 [Filed $12-5-62$ as AD 715 , Eff. $1-1-63$

Renumbered from 603-26-090

Repealed by AD 1080(4-76),

Filed and Eff. 2-3-76]

Requirements for Regtstration of Contract Feeders. Intesrated Feeder-Processors. or Eeeders

603-58-046 (1) The provisions of ORS 633 . 015 and 633.029 shall apply to any person who is a contract feeder or who mixes or processes medicated feed for his own animals, if the animals fed or intended to be fed are maintained for thelr production of m1lk, meat, or eggs for human consumption, if such person either:

(a) Uses a medicated feed additive premix as defined in subsection (3) of OAR 603-58001 containing one of the following drugs elther singularly or in combination:

Aklomide (greater than 0.1\%)

Amprollum (greater than 0.05\%)

Bambermycins

Euqinolate

Carbadox (greater than $500 \mathrm{~g} / \mathrm{t}$ )

Carbarsone (greater than 0.225\%)

Clopidol

Coumaphos

Decoquinate

DES

Dichlorvos (greater than $0.768 \%$ )

Dimethridazole (greater than 0.18 )

Erythronycin

Griseofulvin

Hygromycin B (greater than $32 \mathrm{~g} / \mathrm{t}$, poultry only)

Ipronidazole (greater than 0,0625\$)

Levamisole HCL

MGA

Monensin sodium

Nequinate

Nihydrazone

Nitromide + Sulfanitran

Oleandomycin

Poloxalene

Pryantel tartrate (greater than $800 \mathrm{~g} / \mathrm{t}$ )

Robentdine HCL

Ronnel

Sulfadimethoxine + Ormetoprim

Th1abendazole

Tylosin (greater than $200 \mathrm{~g} / \mathrm{t}$

poultry, greater than $500 \mathrm{~g} / \mathrm{t}$ swine)

Tylosin + Sulfamethazine (each

greater than $500 \mathrm{~g} / \mathrm{t}$ )

zoalene (greater than $0.0375 \%$ ); or

(b) Uses a medicated feed additive premix containing drugs other than those listed in paragraph (a) of this section, and maintains and reeds animals in volumes greater than one or more of the following:

(A) Beef cattle: annual average of 200 head or more per year;

(B) Dairy cattle: annual average herd size of 200 head or more; 
(C) Sheep: annual average of 200 head or tore per year;

(D) Swlne: annual average of 150 head or more per year;

(E) Chickens:

(1) Brollers: annual average of 40,000 birds or more per brood;

(11) Layers: annual average of 10,000 birds or more per brood;

(F) Turkeys: annual average of 13,000 birds or more per brood;

(G) Flsh: annual average of 750,000 1bs. or more of live welght per year.

(2) Any person weeting the criteria of paragraph (b) of subsection (1) of this section is exempted if the medicated feed additive premix used is ntop-dressed" on a complete feed in a reeding receptacle, is not ulxed or comingled prior to placement in such feeding receptacle, and 1 s consistently not adminlstered by. such person wthin 14 days of slaughter of meat animals, ollking or collection of egss for human consumption.

(3) Every person subject to the prov1sions of ORS 633.015 and 633.029 under this section shall malntain records as required in ORS 633.037 and in addition shall maintain records as to:

(a) numbers of animals maintained and red; and

(b) disposition of animals or products for human consumption therefrom.

(4) The fees payable by such persons shall be the same as established by $O A R$ $603-58-065$ and $603-58-070$ and shall be assessed on each wixing or manuracturing 10cation.

Statutory Authority:

Hist: Flled and Eff. 2-3-76 as AD $1080(4-76)$

$603-58-050$ [F1]ed $12-5-62$ as AD 716 , Eff. $1-1-63$ Amended by $A D$ 813(1-66), Filed and Erf, $1-13-66$ Renumbered from 603-26-190 Repealed by AD 107(17-75), Filed and Eff. 11-20-75]

\section{Eroof of labeling clatims or Guarantess} $603-58-051$ (1) For the purpose of ORS
633.055, the department may Investigate and require the submission of evidence to support any labeling clalm or guarantee that Is made, in accordance with OnS 633.025 or 633.027, in any label, Involce, or accompanying pamphiets or brochures intended to Inforw a purchaser of the product's use, value, quallty, analyals, type, or composition.

(2) In its investigation and evaluation of evidence, the department may rely on experimental data, manufacturers' evaluatlons, and advice or data from agricultural experiment stations or other authoritative sources.

Statutory Authority:

Hist: F1led and Eff. $2-3-76$ as AD $1080(4-76)$

Inspection Fees

603-58-055 [F1led 12-22-59 as AD 629
Amended by AD $813(1-66)$,
F1led and Eff $1-13-66$
Renumbered from $603-26-115$
Repealed by AD $1071(17-75)$,
Filed and EFf. $11-20-75]$

603-58-060 [F1]ed $3-18-68$ as AD $870(3-68)$, EIf. $4-1-68$ Renumbered from 603-26-120 Repealed by AD $1080(4-76)$, Filed and Eff. 2-3-76]

Heense Fee for Feed Manufacturers, Wholesale Distributors, Commercial Feed Reststrants and Feeders

+ 603-58-065 The 11cense ree for persons operating a feed manufacturing plant, or acting as a wholesale distributor of feeds, or registering feeds for distribution in oregon, or acting as contract feeders, or feeders of thelr own stock and drugs in any form are utllized by them in the manufacturing, mixing, or processing of feed, shall be 50 which fee is payable at the time an application for licerise is made to the department.

Statutory Authority: 
Hist: Filed $11-26-71$ as AD $958(24-71)$, Eff. 12-15-71

Feed Reglstration Fee

603-58-070 The reglstration fee for each formula or formulation of comercial feed under each brand shall be $\$ 20.00$, which fee is payable at the time an application for registration is made to the department.

Statutory Author 1 ty :

Hist: Filed $11-26-71$ as AD $958(24-71)$, Eff. $12-15-71$

603-58-500 [Filed and Eff. 7-1-63 as AD 762

Renumbered from 603-26-507

Repealed 8-20-74 by

AD $1036(26-74)$, Eff. 9-11-74]

$603-58-505$ [Filed $2-20-63$ as AD 719 Amended $6-17-63$ by AD 725 Amended $10-4-63$ by $A D 770$, Eff. $11-1-63$

Renumbered from 603-26-516

Repealed $8-20-74$ by AD $1036(26-74)$, Eff. $9-11-74]$

603-58-510 [Filed and Eff. 12-13-63

as AD 775

Amended by AD 805(12-65),

Filed and Eff. 8-20-65

Amended 6-14-67 by

AD $837(9-67)$,

Eff. 8-1-67

Amended by AD. $885(15-68)$,

Filed and Eff. T-18-68
Amended by $A D$ 945(12-71), Filed and Eff. 9-1-71

Renumbered from $603-26-530$

Repealed by AD 7-1977,

Flled and E[f. 4-5-77]

603-58-515 [Filed and Eff. 1-13-66 as AD $813(1-66)$

Amended $12-20-66$ by

AD $828(15-66)$, Eff. 1-1-67

Renumbered from 603-26-515

Repealed 8-20-74 by

AD $1036(26-74)$, Eff. $9-11-74]$

$603-58-520$ [Renumbered from 603-26-545

Renumbered to $603-57-215$ by

AD $1036(26-74)]$

603-58-525 [Filed 7-23-70 as

AD $924(10-70)$, Eff. $8-25-70$

Renumbered from 603-26-550

Repealed $8-20-74$ by

AD $1036(26-7.4)$,

Eff. 9-11-74]

603-58-530 [Filed $7-23-70$ as

AD 924) $10-70)$, Eff. 8-25-70

Renumbered from 603-26-555

Repealed 8-20-74 by

AD $1036(26-74)$, Eff. 9-11-74]

603-58-535 [F1]ed $7-23-70$ as AD 924) 10-70), Eff. 8-25-70 Renumbered from 603-26-560 Repealed $8-20-74$ by AD $1036(26-74)$, Ef $[9-11-74]$ 